\title{
Energy Return on Investment from Recycling Nuclear Fuel
}

\author{
U.S. Department of Energy Idaho Operations
}

\author{
Nuclear Energy Contract Number: DE-NE0000291
}

\section{Prepared by: AREVA Federal Services LLC}

\section{August 16, 2011}

REVISION LOG

\begin{tabular}{|c|c|c|c|}
\hline Rev. & Date & Affected Pages & Revision Description \\
\hline 0 & $7 / 28 / 2011$ & & Initial Draft for Review \\
\hline 1 & $8 / 15 / 2011$ & & Final Draft for review \\
\hline 2 & $8 / 17 / 2011$ & lii,2,25 & Final \\
\hline 3 & $9 / 1 / 2011$ & 25 & Changed natural uranium to depleted uranium \\
\hline & & & \\
\hline
\end{tabular}




\section{TABLE OF CONTENTS}

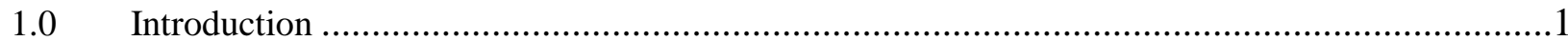

2.0 Energy Return on Investment For One Pass Scenario ....................................................2

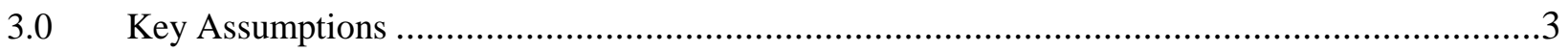

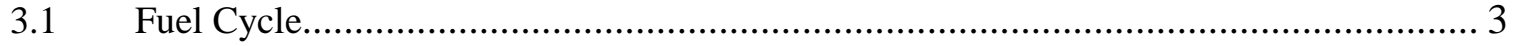

3.2 The Energy Resource: Used Nuclear Fuel …............................................................ 5

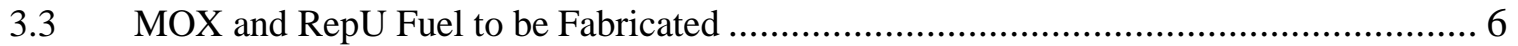

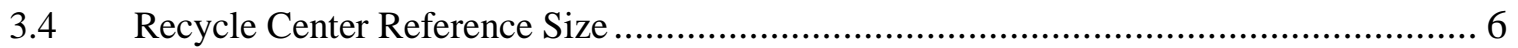

3.5 Fabrication Plants (MOX/RepU) Size ......................................................... 6

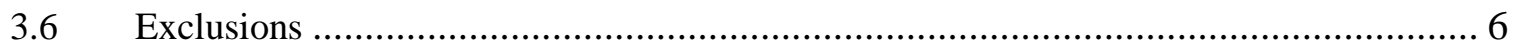

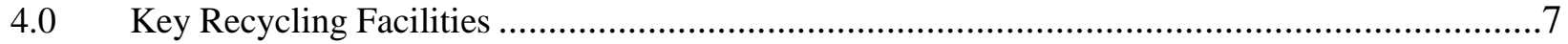

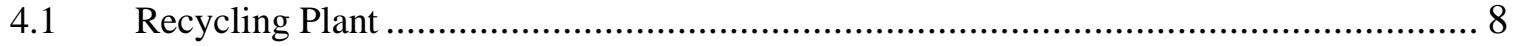

4.1.1 Fuel Receipt \& Storage (FRS) Facility ................................................. 8

4.1.2 Shearing/Dissolution/Compaction Facility ............................................ 8

4.1.3 Separation/Purification/Concentration Facility......................................... 8

4.1.4 Fission Product Vitrification Facility ….................................................... 8

4.1.5 High Active Solid Waste Storage Facility............................................... 8

4.1.6 Liquid and Solid Waste Treatment Facility............................................... 8

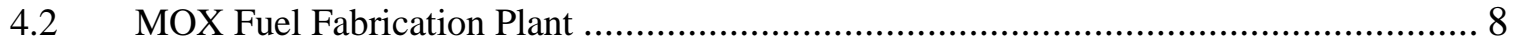

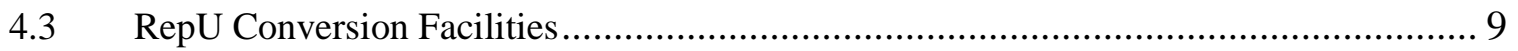

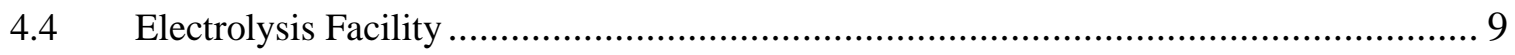

$4.5 \quad$ RepU Enrichment Facility ................................................................................ 9

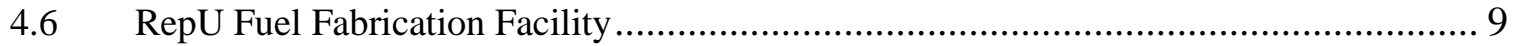

$5.0 \quad$ PRIMARY ENERGY CONSUMPTION DATA.........................................................

5.1 Estimated Energy to Operate the 800 tHM/y Recycle Facilities ................................. 10

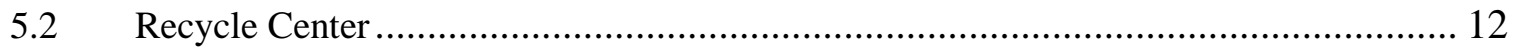

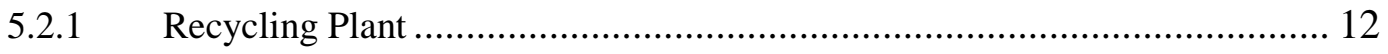

5.2.2 MOX Fuel Fabrication Plant …............................................................ 14

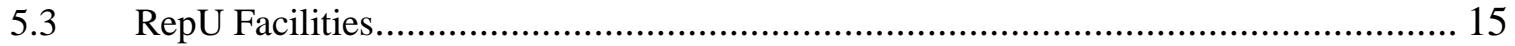

5.3.1 RepU Conversion Facilities ................................................................. 15

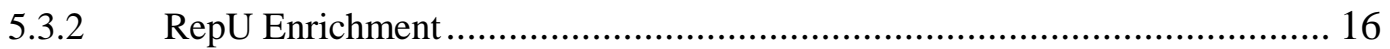

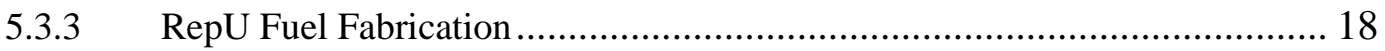




\section{TABLE OF CONTENTS (CONT).}

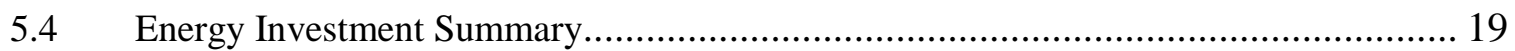

5.5 Energy Required to Construct and Decommission Recycling Facilities ...................... 19

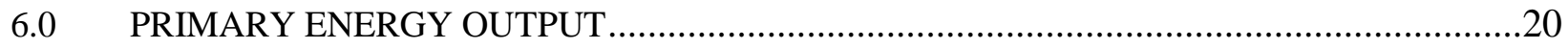

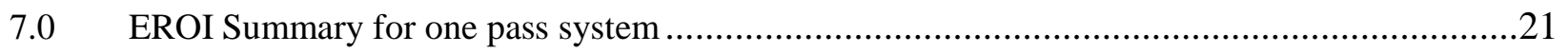

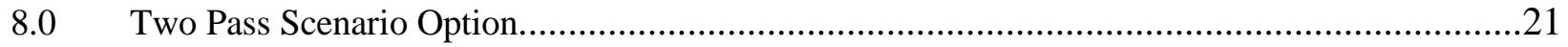

9.0 Recycle of the used fuel from the One-Pass system in a Sodium Fast Reactor.........................22

9.1 Energy Required to Build and Decommission Sodium Fast Reactor ........................... 23

9.2 Total Energy Return on Investment for The SFR Recycle...................................... 24

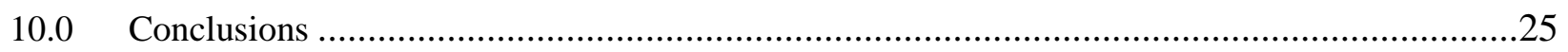

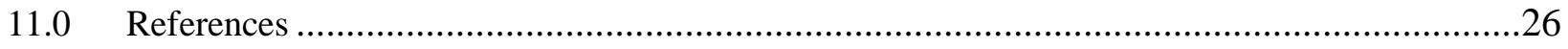




\section{LIST OF FIGURES}

Figure 1. EROI Concept (One-Pass Recycle Option) ...........................................................2

Figure 2. LWR Used Nuclear Fuel Cycle (One-Pass Recycle Option).....................................4

Figure 3. La Hague Plant Energy Consumption vs. Throughput .............................................12

Figure 4. Results of Energy Return on Investment for Scenario's Considered in this Report ....25 


\section{LIST OF TABLES}

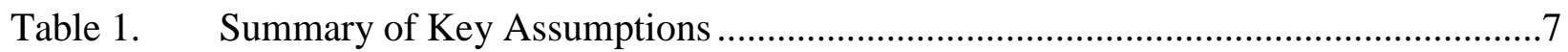

Table 2. $\quad$ Energy Consumption (Recycle Center \& RepU Facilities) ..........................................11

Table 3. La Hague Energy Consumption vs. Throughput .................................................13

Table 4. Estimated Energy Consumption (800 tHM/Y Recycling Plant)...............................14

Table 5. Melox Energy Consumption vs. Fuel Fabrication Throughput ..................................14

Table 6. URENCO Enrichment Consumption Data ...............................................................17

Table 7. FBFC Romans Energy Consumption vs. Fabricated $\mathrm{UO}_{2}$ Throughput .....................18

Table 8. Summary of Energy Investment .........................................................................19

Table 9. Summary of Energy Consumed, by Phase, Area and Type .......................................20

Table 10. Summary of Annual Energy Produced ...................................................................20

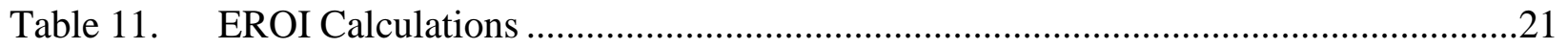

Table 12. Energy Concumed and Produced for Twice-Through Recycle...............................21

Table 13. Complete Energy Return on Investment for Twice Through Recycle. .....................22

Table 14. Summary of Annual Energy Produced and Consumed in Fast Reactor Fuel Cycles for Burner SFR With CR <1 .....................................................................22

Table 15. Summary of Annual Energy Produced and Consumed in Fast Reactor Fuel Cycles for Break Even SFR CR $\approx 1$...........................................................................23

Table 16. Summary of Annual Energy Produced and Consumed in Fast Reactor Fuel Cycles for Breeder SFR CR>1..............................................................................23

Table 17. Summary of Energy Consumed During Construction and Decommissioning of a SFR.

Table 18. Energy Required to Construct and Decommission SFRS's to Support Scenarios Described in Report...............................................................................24

Table 19. Complete EROI Calculations for SFR Scenarios Considered in Report ...................24 


\section{$1.0 \quad$ INTRODUCTION}

Energy Return on Investment (EROI) is defined as the ratio of final energy produced to final energy invested (or consumed) in the process. Final energy is defined as energy in forms readily usable by consumers, such as gallons of gasoline, megawatt-hours of electrical energy, or cubic feet of natural gas. All forms of final energy are derived from an energy resource, such as oil in the ground. The resource must be extracted and processed in some way to convert it into final energy, such as gasoline. These extraction and processing actions themselves require investment (or consumption) of energy. Of course, the final energy produced from the resource should be many times greater than the final energy invested in the extraction and processing actions.

This report presents an evaluation of the EROI from recycling an initial batch of $800 \mathrm{t} / \mathrm{y}$ of used nuclear fuel (UNF) through a Recycle Center under a number of different fuel cycle scenarios. The study assumed that apart from the original $800 \mathrm{t}$ of UNF only depleted uranium was available as a feed. Therefore for each subsequent scenario only fuel that was derived from the previous fuel cycle scenario was considered. The scenarios represent a good cross section of the options available and the results contained in this paper and associated appendices will allow for other fuel cycle options to be considered.

Scenario 1: Produce both plutonium-uranium mixed oxide (MOX) fuel and reprocessed uranium (RepU) fuel for use in existing light water reactors (LWRs) (One-Pass Recycle Option).

Scenario 2: Recycle of the used MOX and RepU UNF from Scenario 1 for use in LWRs again, a TwoPass Recycle Option. In this scenario, the fissile material is used three times: once as fresh fuel in an LWR and twice more as recycled fuel in LWRs.

Scenario 3: Operation of sodium fast reactors (SFRs) to obtain additional energy from the used nuclear fuel available after Scenario 1 considering 3 different conversion ratios (CRs) for the core operation namely CR of 0.3 (Burner), a CR of 1 (Neutral) and a CR of 1.2 (Breeder). In this scenario, the fissile material is used three times: once as fresh fuel in an LWR, once as recycled fuel in an LWR, and finally as recycled fuel in an SFR.

This report does not include any discussion of the once-through (open) fuel cycle and is not a comparison with the once-through fuel cycle. Calculations of the EROI of the once-through fuel cycle have been presented by other entities (example: World Nuclear Association [1]). Thus, this report does not include any estimates of the energy consumption during natural uranium (NatU) mining, ore processing, enrichment, etc. Instead, this report considers the energy resource to be the used nuclear fuel from LWRs. It is assumed that the acquisition of this resource requires no additional energy investment at all because it is currently stored at existing LWRs.

For completeness the report estimates the energy that would be required to build and decommission any of the facilities that are specifically required to extract energy from the UNF. This includes the recycling facilities, specific RepU Facilities and the SFR. It does not include the construction and dismantlement of LWRs. 


\subsection{ENERGY RETURN ON INVESTMENT FOR THE ONE PASS RECYCLE SCENARIO}

Figure 1 provides a graphic illustration of the EROI concept for the one-pass recycle option. In this calculation, the final energy produced is defined as the electrical energy produced (to the grid) from loading the recycled MOX and RepU fuel in existing operating LWRs. The final energy invested (or consumed) is defined as the electrical energy and thermal energy (natural gas) that is invested (or consumed) in operating the following facilities:

$>$ Recycle Center Facilities

- Recycling Plant (including associated waste treatment facilities)

- MOX Fuel Fabrication Plant

$>$ RepU Processing Facilities

- Conversion to $\mathrm{UO}_{3}$

- Conversion to $\mathrm{UF}_{6}$

- Conversion to $\mathrm{U}_{3} \mathrm{O}_{8}$

- Electrolysis

- Enrichment of RepU

- Conversion to $\mathrm{UO}_{2}$ and RepU Fuel Fabrication Facility

Figure 1. EROI Concept (One-Pass Recycle Option)

\section{$E R O I=\frac{\text { Final Energy Output }}{\text { Final Energy Investment }}$}

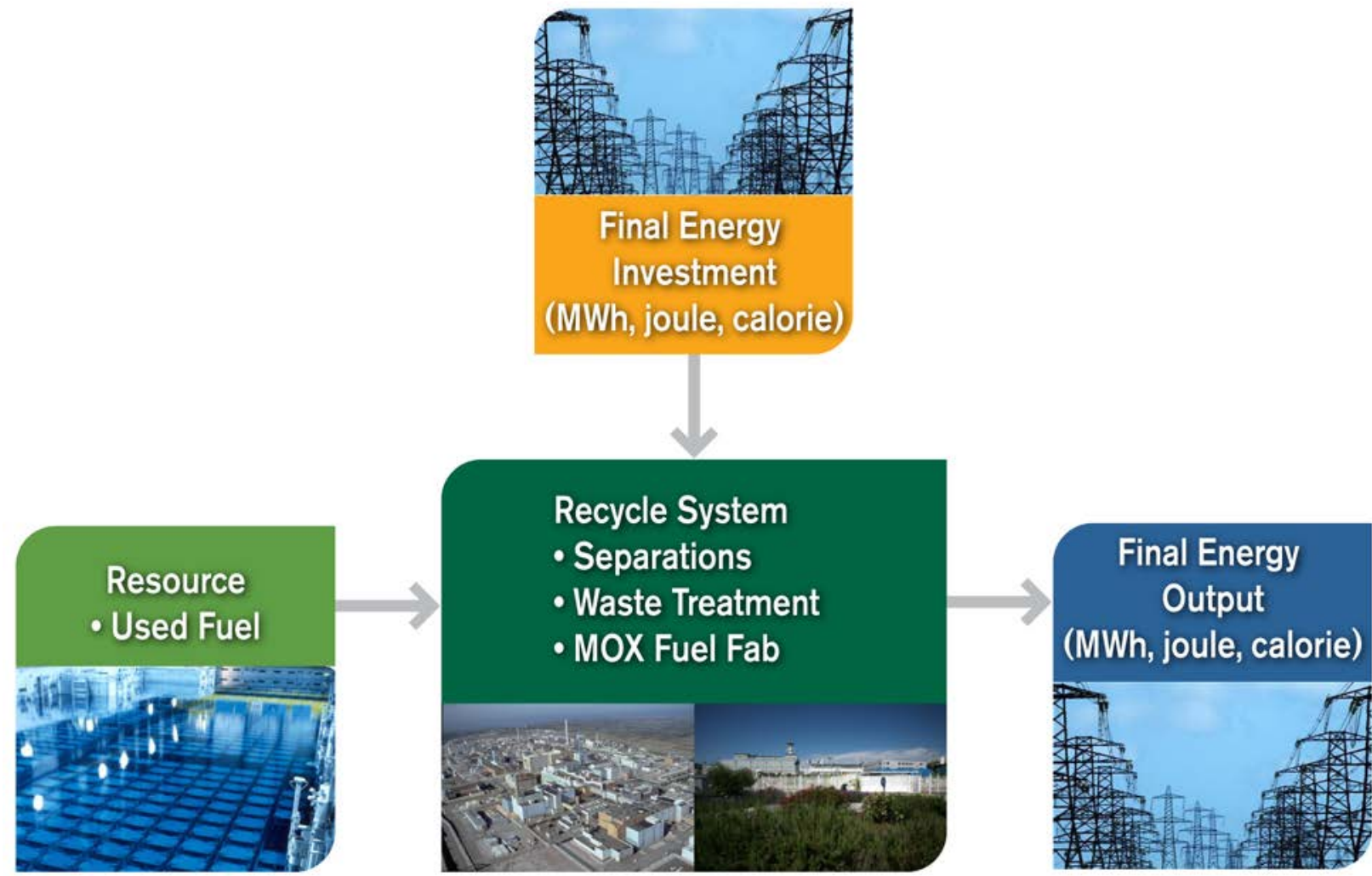


The Recycle Center is sized to process 800 metric tons of heavy metal of used nuclear fuel (UNF) per year (800 tHM/y). The energy consumption for an $800 \mathrm{tHM} / \mathrm{y}$ Recycle Center is extrapolated from actual operational data of similar recycling facilities in France (La Hague Recycling Plant and MELOX MOX Fuel Fabrication Plant).

\subsection{KEY ASSUMPTIONS}

This section describes the key assumptions used in the EROI evaluation.

\subsection{FUEL CYCLE}

The EROI calculation is based on the fuel cycle shown in Figure 2. The material flow is based on the PUREX recycling technology currently in use at the LaHague Recycling Plant. 
Figure 2. LWR Used Nuclear Fuel Cycle (One-Pass Recycle Option)

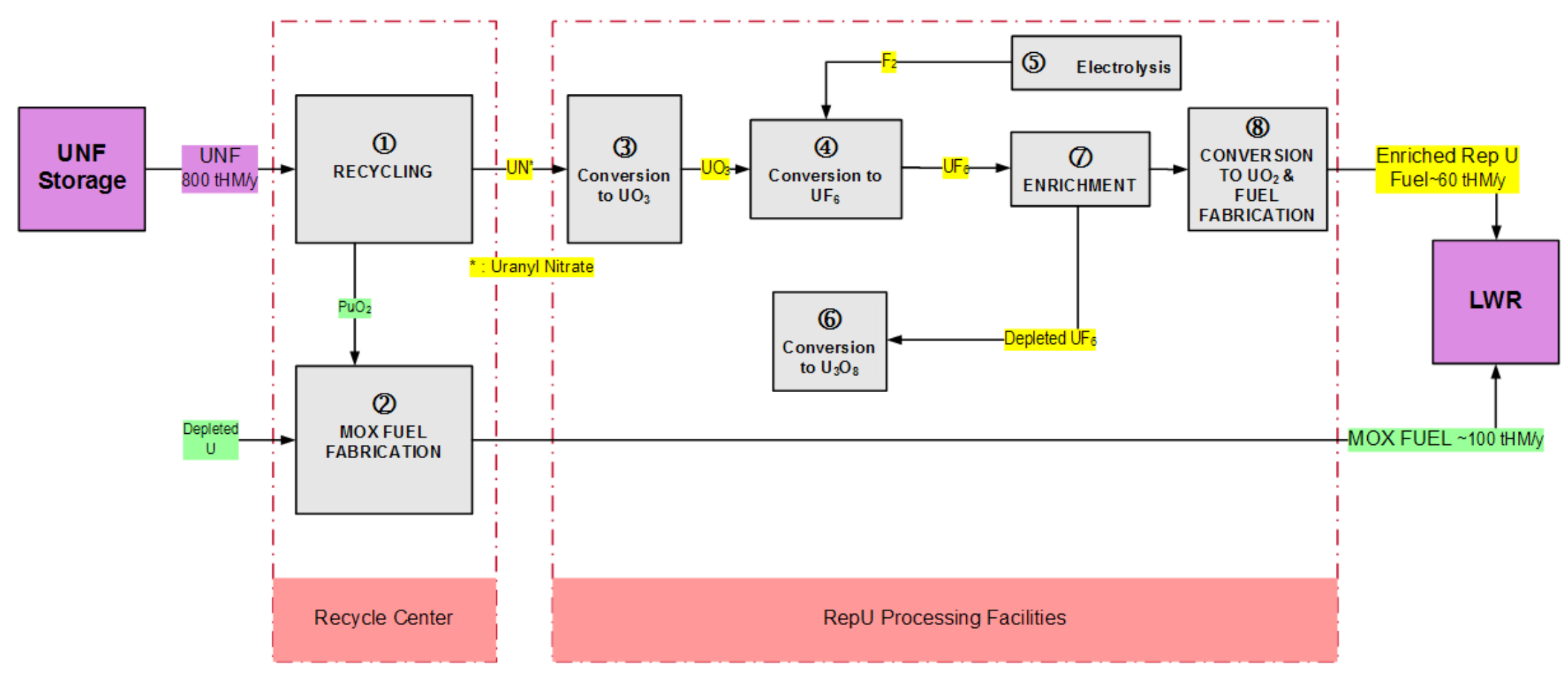


In this fuel cycle scenario, the plutonium is recovered from the UNF and used to fabricate MOX fuel and the recovered uranium is converted, enriched, and fabricated into RepU fuel. The final energy output is electrical energy produced (to the grid) from loading the MOX and RepU fuel into operating LWR's. The main facilities in this figure are numbered from 1 through 8 . These facility numbers will be used in Sections 3.0 and 4.0 to describe the functions of the facilities and to tabulate their final energy investments (consumptions).

A description of the two large boxes shown in Figure 2 is provided below:

Recycle Center: This box shows the facilities that are associated with the Recycle Center this analysis assumes will be constructed in the United States to recycle LWR used nuclear fuel. The Recycle Center facilities should be located on the same site due to process considerations, safety and security (no transportation of Pu powder between facilities), and operational cost considerations (waste management, etc.). Additional information on these facilities is discussed in Section 4.0 (Key Recycling Facilities) and Section 5.0 (Final Energy Consumption Data) of this report.

RepU Processing Facilities: This box shows the facilities associated with processing the RepU fuel recovered from the recycling of the LWR used nuclear fuel in the Recycle Center. This analysis assumes that some of the RepU fuel processes are performed in RepU “dedicated” facilities while other RepU fuel processes will be integrated into "existing” natural uranium (NatU) facilities. The dedicated conversion facilities are required to prevent contamination of the UOx lines with $\mathrm{U}^{232}$.

The list below identifies the different processes associated with recovery, conversion, and fabricating RepU fuel and the associated type of facility (“dedicated" or "existing”) in which the process will be located.

$>$ "Dedicated" Facilities

- Conversion to $\mathrm{UO}_{3}$ (Box 3 in Figure 2)

- Conversion to $\mathrm{UF}_{6}$ (Box 4 in Figure 2)

- Conversion to $\mathrm{U}_{3} \mathrm{O}_{8}$ (Box 6 in Figure 2)

"Existing” Facilities

- Electrolysis (Box 5 in Figure 2)

- Enrichment (Box 7 in Figure 2)

- Conversion to $\mathrm{UO}_{2}$ \& Fuel Fabrication (Box 8 in Figure 2)

The RepU Processing Facilities do not have to be collocated with the Recycle Center. Additional information on these facilities is discussed in Section 3.0 (Key Recycling Facilities) and Section 4.0 (Final Energy Consumption Data) of this report.

\subsection{THE ENERGY RESOURCE: USED NUCLEAR FUEL}

The energy resource is assumed to be used UOx fuel that was burned in LWRs (box labeled UNF Storage on the left side of Figure 2). It is intended to represent an average of the U.S. reactor fleet. The discharge burn-up is assumed to be $50 \mathrm{GWD} / \mathrm{t}$. This is a batch-average burn-up, with some fuel assemblies having a higher burn-up and some having a lower burn-up. The initial enrichment required to achieve this burn-up is assumed to be $4.1 \% \mathrm{U}^{235}$. These two assumptions, along with a cooling time of 4 years, yield the plutonium isotopic composition, or plutonium quality assumed to exist in the used nuclear fuel. This is the starting point, or the energy resource, for this EROI calculation. 


\subsection{MOX AND REPU FUEL TO BE FABRICATED}

The MOX and RepU fuel to be produced in these facilities is assumed to contain sufficient fissile material to achieve a discharge burn-up which is the same as the UOx fuel, or $50 \mathrm{GWD} / \mathrm{t}$. These assumptions are summarized in Table 1 . The MOX fuel is composed of the plutonium recovered from the recycled LWR used nuclear fuel. This plutonium is converted to an oxide and is mixed with fresh uranium tails material with an assumed composition of $0.25 \% \mathrm{U}^{235}$ left over from the enriching of fresh natural uranium used to manufacture fresh UOx. The amount of plutonium is 9.6 weight-percent of the total heavy metal in the MOX fuel.

The uranium in the UNF is the resource for the RepU fuel. This material is assumed to have a nominal enrichment of 0.76 weight-percent. After it is separated from the UNF, this material must be enriched to about 5 weight-percent to achieve the same $50 \mathrm{GWD} / \mathrm{t}$ discharge burn-up as the initial fresh UOx fuel.

\subsection{RECYCLE CENTER REFERENCE SIZE}

The assumed capacity of the reference Recycle Center is 800 tHM/y. The Recycle Center includes both the aqueous recycling facilities for UNF uranium oxide (UOx) and the associated waste treatment.

\subsection{FABRICATION PLANTS (MOXIREPU) SIZE}

The fuel fabrication facilities are sized to match the product (Pu/RepU) from the $800 \mathrm{tHM} / \mathrm{y}$ Recycle Center. The Recycle Center produces LWR MOX fuel while the RepU fuel is produced in a UOx fuel fabrication facility. The MOX fuel contains the plutonium from the recycled LWR used nuclear fuel and the RepU fuel contains the uranium which has been enriched from the average assumed discharge enrichment of approximately $0.76 \% \mathrm{U}^{235}$ to an enrichment of about $5 \%$.

\subsection{EXCLUSIONS}

Only energy consumption parameters that have significant impact on EROI calculation are included in this evaluation. The following energy consumption parameters are excluded:

$>$ Transportation of used nuclear fuel elements to the Recycle Center

$>$ Transportation of workers

$>$ Manufacturing and transportation of fuel cladding

$>$ Transportation of small quantity of depleted uranium used in MOX fabrication

$>$ Manufacturing and transportation of reagents

The EROI evaluation does not consider normalization of climate conditions for heating and cooling of a Recycle Center located in the United States since a specific site for the Recycle Center has not been identified. The energy used for heating and cooling of the Recycle Center facilities in France is included in the actual plant energy usage data contained in this report. The climate in France in the vicinity of the La Hague and MELOX Plants is considered a moderate climate. 
Table 1. Summary of Key Assumptions

\begin{tabular}{|l|l|}
\hline Parameter & Assumed Value \\
\hline UOx Fuel & \\
\hline UOx Initial Enrichment & $4.1 \% \mathrm{U}^{235}$ \\
\hline UOx Discharge Burnup & $50 \mathrm{GWD} / \mathrm{t}$ \\
\hline Cooling Time Before Recycling & 4 years \\
\hline MOX Fuel & \\
\hline Recycle Center Capacity & $800 \mathrm{tHM} / \mathrm{y}$ \\
\hline MOX produced & $100 \mathrm{t} / \mathrm{y}$ \\
\hline Pu throughput & $9.6 \mathrm{t} / \mathrm{y}$ \\
\hline Percent Pu in heavy metal & $9.60 \%$ \\
\hline Enrichment of uranium in MOX fuel & $0.25 \% \mathrm{U} 235$ \\
\hline MOX Discharge Burnup & $50 \mathrm{GWD} / \mathrm{t}$ \\
\hline RepU Fuel & \\
\hline RepU produced & $748 \mathrm{t} / \mathrm{y}$ \\
\hline Percent of U35 in RepU & $0.76 \%$ \\
\hline RepU Fuel Produced & $59 \mathrm{t} / \mathrm{y}$ \\
\hline RepU Fuel Enrichment & $5 \% \mathrm{U} 235$ \\
\hline RepU Discharge Burnup & $50 \mathrm{GWD} / \mathrm{t}$ \\
\hline
\end{tabular}




\subsection{KEY RECYCLING FACILITIES}

The key facilities considered in the EROI evaluation include the Recycle Center (Recycling Plant and MOX Fuel Fabrication Plant) and the RepU Processing Facilities (RepU Conversion Facilities, Electrolysis Facility, RepU Enrichment Facility, and RepU Fuel Fabrication Facility). Each of these facilities is described in this section.

\subsection{RECYCLING PLANT}

The Recycling Plant (Box 1 in Figure 2) receives the UNF UOx fuel, removes the end pieces and metal clad, dissolves the spent UOx fuel pellets, and separates the uranium and plutonium from the fission products and other actinides. The fission products and minor actinide waste stream is also stabilized in this facility.

The Recycling Plant includes a number of operations, which are described below.

\subsubsection{FUEL RECEIPT \& STORAGE (FRS) FACILITY}

The function of the FRS Facility is to receive casks containing UNF, conduct cask maintenance, and transfer the UNF using either dry or wet fuel unloading techniques to a storage pool.

\subsubsection{SHEARING/DISSOLUTION/COMPACTION FACILITY}

Fuel assemblies are taken from the storage pool and transferred into the shearing machine. The UNF is cut into rod sections that are transferred to the dissolver. The end pieces and empty rod sections (hulls) are cleaned and size reduced by compaction.

\subsubsection{SEPARATION/PURIFICATION/CONCENTRATION FACILITY}

The separation and purification process is based upon countercurrent liquid-liquid extractions. The solvent used is TBP diluted in dodecane diluent.

\subsubsection{FISSION PRODUCT VITRIFICATION FACILITY}

The purpose of the vitrification unit is to prepare solutions for the vitrification process, and to incorporate the High Active Liquid Waste (HALW) and undissolved fines into a glass matrix using a cold crucible melter. The glass is poured into canisters which are sent to the appropriate storage facility.

\subsubsection{HIGH ACTIVE SOLID WASTE STORAGE FACILITY}

Compacted waste canister storage is designed for the interim storage of the compacted waste canisters from compaction unit.

\subsubsection{LIQUID AND SOLID WASTE TREATMENT FACILITY}

This facility is dedicated to the treatment of the liquid and solid wastes generated in the plant. In the liquid waste treatment area, the main function is liquid waste decontamination by concentration and evaporation.

\subsection{MOX FUEL FABRICATION PLANT}

The MOX Fuel Fabrication Plant (Box 2 in Figure 2) takes the plutonium product of the Recycling Plant and produces MOX fuel assemblies. The facility contains process equipment in glove boxes inside process cells dedicated to the LWR MOX fuel fabrication and associated storage areas. The process mixes the $\mathrm{PuO}_{2}$ powder and uranium oxides with recycled scrap powder to form MOX fuel pellets. The pellets are loaded into fuel rods, which are then assembled into (U, Pu) fuel assemblies for use in LWRs. 
The fabrication of MOX fuel is similar to that of uranium oxide fuels. It is performed in the following phases:

$>$ Mixing the powders

$>$ Sintering

$>$ Grinding

$>$ Graining (inserting pellets into zirconium rods)

$>$ Assembly (final stage - inserting rods into metal structures to form fuel assemblies for loading into LWRs).

It is important to note that the current design constraints on the LWR MOX Fuel Fabrication Plant restrict the concentration of $\mathrm{Pu}$ in the fabrication process to less than 12.5 weight-percent.

\subsection{REPU CONVERSION FACILITIES}

The RepU Conversion Facilities (Boxes 3, 4, and 6 in Figure 2) converts the oxide of the recycled uranium into a fluoride so that it can be enriched. After enrichment, the depleted material is converted to $\mathrm{U}_{3} \mathrm{O}_{8}$ in a RepU plant. These facilities are dedicated RepU facilities in order to avoid contamination of the UOx lines with the $\mathrm{U}^{232}$ isotope in the RepU. $\mathrm{U}^{232}$ has several short-lived decay products, including $\mathrm{T} 1^{208}$, which emits a very strong gamma-ray with an energy level of $3.4 \mathrm{MeV}$.

\subsection{ELECTROLYSIS FACILITY}

In the Electrolysis Facility (Box 5 in Figure 2) gaseous fluorine is produced by using electrolytic cells, which contain molten potassium bifluoride and anhydrous hydrogen fluoride. An electrical current passes through the cell and dissociates the anhydrous hydrogen fluoride into hydrogen and fluorine. Cell temperature is maintained by internal water cooling. The electrolysis process will be performed in existing NatU facilities.

\subsection{REPU ENRICHMENT FACILITY}

The RepU Enrichment Facility (Box 7 in Figure 2) takes the reprocessed uranium, which has a $\mathrm{U}^{235}$ enrichment in the region of $0.76 \%$, and enriches it to about $5 \%$. The enrichment is accomplished in existing NatU Enrichment Facilities, but will have a dedicated line for RepU enrichment. This evaluation assumes the enrichment facility uses the centrifuge process rather than the more energy intensive diffusion process. The input to the process is low-enriched uranium hexafluoride. The enrichment process concentrates the lighter isotopes of uranium, including the $\mathrm{U}_{234}, \mathrm{U}^{235}$, and $\mathrm{U}^{236}$ in the $\mathrm{U}^{238}$. This enriched material is then used in the manufacture of the fuel pellets. The bulk of the material is left with a lower enrichment than it started with and is sent to a waste storage facility.

\subsection{REPU FUEL FABRICATION FACILITY}

This evaluation assumes that an existing LWR Fuel Fabrication Facility (Box 8 in Figure 2) converts the $\mathrm{UF}_{6}$ to $\mathrm{UO}_{2}$ and produces the RepU fuel assemblies. The fuel fabrication is accomplished in existing NatU fuel fabrication facilities, but will contain process equipment dedicated to the LWR RepU fuel fabrication and associated storage areas. Due to the decay products of the $U_{232}$ in the RepU, some of the process equipment is placed behind shielding to reduce worker doses. No glove boxes or hot cells are required. The RepU fuel fabrication process involves manufacturing RepU fuel pellets, loading the pellets into the fuel rods, and assembling the fuel rods to form the fuel assemblies. The steps in the manufacture of the pellets are similar to those described in Section 3.2 for the MOX fuel. 


\subsection{FINAL ENERGY CONSUMPTION DATA}

The final energy consumed in the operation of the Recycle Center is extrapolated from actual energy consumption data from operating Recycling Plant (La Hague) and MOX Fabrication Plant (MELOX) in France. These facilities have the highest energy consumption in a Recycle Center (approximately 90\% of the total energy consumption associated with operating Recycle Center and associated RepU Facilities). Energy consumption for the RepU Conversion, Enrichment, and Fabrication facilities is based on a combination of actual facility operational data as well as engineering analysis of future facilities that AREVA is currently building or planning to build. The actual energy consumption data and the method used to extrapolate to the reference $800 \mathrm{tHM} / \mathrm{y}$ plant are described in this section. The estimated energy consumption of each facility for the $800 \mathrm{tHM} / \mathrm{y}$ plant is summarized in Table 2.

\subsection{ESTIMATED ENERGY TO OPERATE THE 800 tHM/Y RECYCLE FACILITIES}

Table 2 below provides the energy consumption data for the operational facilities in France, as well as the normalized energy consumption estimates for an 800 tHM/y Recycle Center.

The process/analysis associated with determining the energy consumption of the different Recycle Center facilities, as well as the normalization of the operating facilities the $800 \mathrm{tHM} / \mathrm{y}$ reference facility, is discussed in the following sections. 
Task Order 4: Calculation of Energy Return on Investment

Table 2. Annual Energy Consumption (Recycle Center \& RepU Facilities)

\begin{tabular}{|c|c|c|c|c|c|c|}
\hline ALL YEARLY FIGURES & $\begin{array}{l}\text { RECYCLING } \\
\text { (1) }\end{array}$ & $\begin{array}{l}\text { MOX FUEL FABRICATION } \\
\text { (2) }\end{array}$ & $\begin{array}{l}\text { RepU CHEMICAL PROCESSING } \\
\text { conversion to } \mathrm{UF}_{6}(3)+(4)+(5) \\
\text { conversion to } \mathrm{U}_{3} \mathrm{O}_{8} \text { (6) }\end{array}$ & $\mid \begin{array}{c}\text { RepU ENRICHMENT } \\
(7)\end{array}$ & $\begin{array}{l}\text { RepU FUEL } \\
\text { FABRICATION } \\
\text { (8) }\end{array}$ & TOTAL \\
\hline $\begin{array}{l}\text { Reference Plant } \\
\text { Reference Throughput }\end{array}$ & $\begin{array}{c}\text { La Hague } \\
1015 \text { tHM (2006) }\end{array}$ & $\begin{array}{c}\text { MELOX } \\
130 \text { tHM (average 2003-2009) }\end{array}$ & $\begin{array}{l}\text { Project EPICURE* } \\
\text { * See Note } 1 \text { below. }\end{array}$ & $\begin{array}{c}\text { GB II } \\
\text { * See Note } 1 \text { below. }\end{array}$ & $\begin{array}{c}\text { FBFC ROMANS } \\
869 \text { tU/y } \\
\text { (average 2005-2008) } \\
\end{array}$ & \\
\hline Reference Energy Consumption & $690 \mathrm{GWh}$ & $43 \mathrm{GWh}$ & & & $41 \mathrm{GWh}$ & \\
\hline $\begin{array}{r}\text { Incl. Electricity } \\
\text { Incl. Thermal }\end{array}$ & \begin{tabular}{l|}
378 \\
312
\end{tabular} & $\begin{array}{r}38 \\
5\end{array}$ & & & \begin{tabular}{r|}
31 \\
11 \\
\end{tabular} & \\
\hline EROI Study Throughput & $800 \mathrm{tHM}$ & $100 \mathrm{tHM}$ & 748 tHM & $748 \mathrm{tHM}$ & $59 \mathrm{tHM}$ & \\
\hline Estimated Energy Consumption (GWh) & 416 & 43 & 36 & 15 & 3 & 513 \\
\hline $\begin{array}{r}\text { Incl. Electricity } \\
\text { Incl. Thermal }\end{array}$ & $\begin{array}{ll}220 \\
196\end{array}$ & $\begin{array}{r}38 \\
5\end{array}$ & $\begin{array}{l}21 \\
15\end{array}$ & 15 & $\begin{array}{l}2 \\
1\end{array}$ & $\begin{array}{ll}296 \\
217\end{array}$ \\
\hline$\%$ of Total Estimated Consumption & $81.1 \%$ & $8.4 \%$ & $7.0 \%$ & $2.9 \%$ & $0.6 \%$ & \\
\hline
\end{tabular}

Note 1: AREVA does not currently operate equivalent facilities nor access to actual operation energy consumption date. The estimated energy consumption for these facilities is based on detailed design I operational studies for new AREVA facilities currently under development:

* EPICURE - AREVA RepU Conversion Facility

* George Besse II (GBII) - AREVA Enrichment Facility 


\subsection{RECYCLE CENTER}

\subsubsection{RECYCLING PLANT}

This section presents the energy consumption of the Recycling Plant (Box 1 of Figure 2). The energy necessary to recycle $800 \mathrm{tHM} / \mathrm{y}$ of UNF is based on actual energy usage data from AREVA's La Hague Plant that has a throughput capacity of 1,600 tHM/y (note: La Hague has two operational lines designed for recycling $800 \mathrm{tHM} / \mathrm{y}$ each).

\section{La Hague Energy Consumption Data}

Figure 3 and Table 3 provide the La Hague Plant's energy consumption data [3] for years 2004 to 2009 (note: latest available information data/Figure 3 only shows 5 data points since data for years 2004 and 2005 are nearly the same throughput).

Figure 3. LA Hague Plant Energy Consumption vs. Throughput

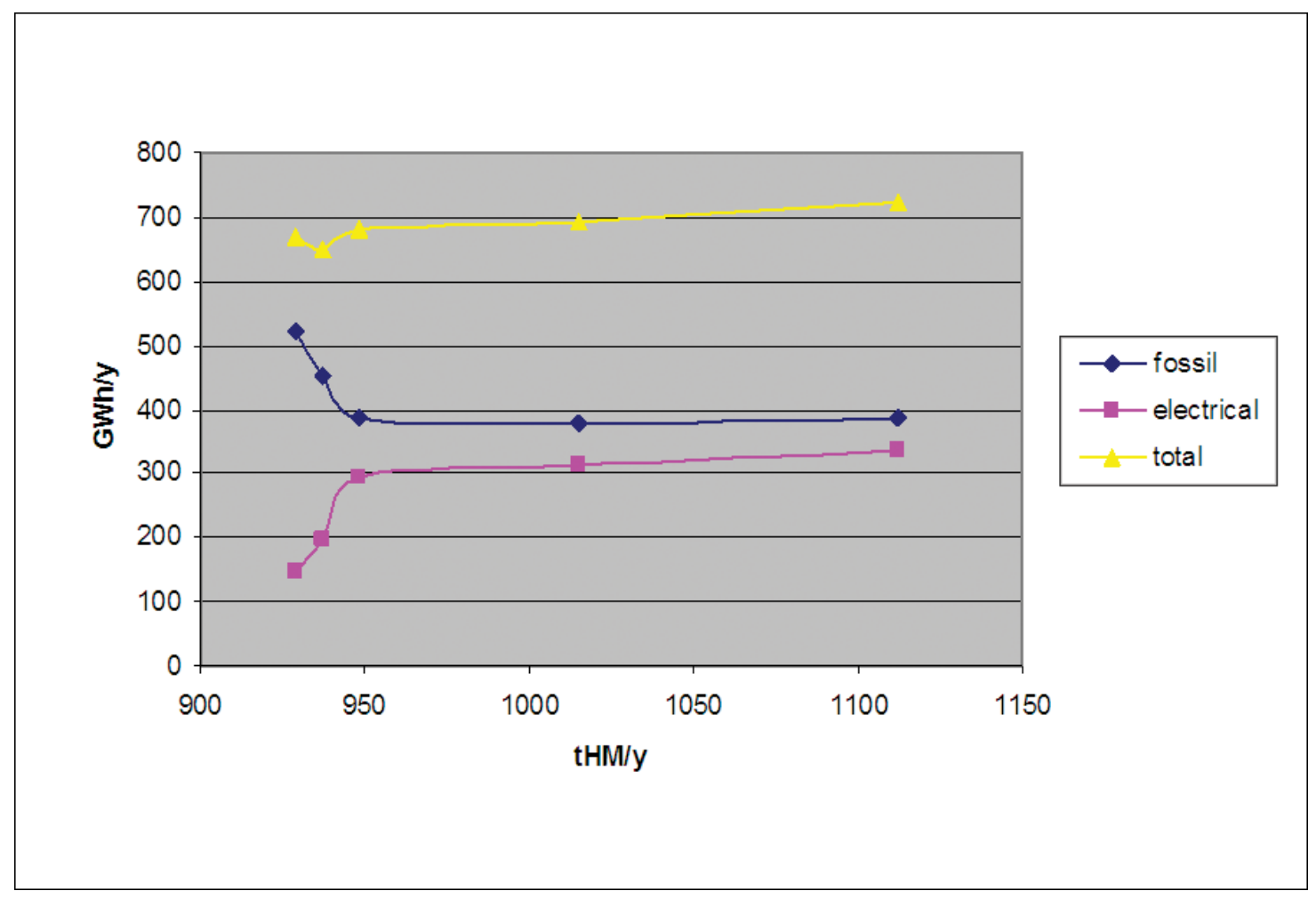

As shown in Table 3, the overall energy consumption is not significantly different from one year to another, and roughly correlates with the throughput. The evolution within the last two years (2008 and 2009) of the energy distribution (fossil fuel vs. electricity) derives from the replacement of steam generators from fuel oil type to electrical type. The thermal energy from fossil fuels is used primarily to heat facilities and operate limited plant components. 
Table 3. LA Hague Energy Consumption vs. Throughput

\begin{tabular}{|l|c|c|c|c|c|c|}
\cline { 2 - 7 } \multicolumn{1}{c|}{} & $\mathbf{2 0 0 4}$ & $\mathbf{2 0 0 5}$ & $\mathbf{2 0 0 6}$ & $\mathbf{2 0 0 7}$ & $\mathbf{2 0 0 8}$ & $\mathbf{2 0 0 9}$ \\
\hline Recycled UNF (tHM/y) & 1100 & 1112 & 1015 & 948 & 937 & 929 \\
\hline Electricity Consumption (GWh/y) & 399 & 386 & 378 & 387 & 425 & 521 \\
\hline Thermal Energy Consumption (GWh/y) & 334 & 336 & 312 & 292 & 198 & 148 \\
\hline Total (GWh/y) & 733 & 722 & 690 & 679 & 623 & 669 \\
\hline
\end{tabular}

In the EROI calculation, the energy consumption for 2006 is used as representative of typical operation of the La Hague Plant in terms of both throughput and typical climate conditions. In addition, precise distributions of the energy consumption between the following systems for La Hague plant (including associated waste treatment plants) are available:

$>$ Process,

$>$ Ventilation,

$>$ Utilities,

$>$ Heating,

$>$ Lighting,

$>$ Monitoring,

$>$ Others (transportation, energy losses, etc.)

\section{Energy Calculation for the $\mathbf{8 0 0}$ tHM/y Reference Plant}

The La Hague plant is composed of two plants: UP3 and UP2-800 which are designed for each to process a maximum of $800 \mathrm{tHM} / \mathrm{y}$. The reference $800 \mathrm{tHM} / \mathrm{y}$ Recycle Center is therefore comparable to one of these two plants. However, the treated throughput of La Hague plant is lower than the design throughput of $1600 \mathrm{tHM} / \mathrm{y}$, so the energy consumption factor cannot be simply extrapolated from the La Hague operational data.

For parts of the La Hague plant, the energy consumption is dependent on the size the plant (ventilation, heating, lighting, monitoring, etc.), whereas energy consumption for other parts of the plant depend on the treated throughput of UNF (process, utilities).

For each of the plant systems listed above, either a volume factor (VF) or a throughput factor (TF) is applied as follows:

The volume factor corresponds to the sum of the volumes of the main process buildings of the reference $800 \mathrm{tHM} / \mathrm{y}$ plant (which are the main contributors to the energy consumption) divided by the sum of the volumes of the main process buildings of La Hague plant (UP3 + UP2-800). The assumption was made in this calculation that the other buildings (storage pools, control rooms, etc) will contribute in the same proportion.

The individual buildings associated with the reference $800 \mathrm{tHM} / \mathrm{y}$ plant and the La Hague plant is described in Reference [2].

The result of this calculation gives a volume factor equal to: $\mathrm{VF}=42 \%$.

The VF factor is applied to the following energy consumptions:

$>$ Ventilation,

$>$ Heating,

$>$ Lighting,

$>$ Monitoring,

$>$ Others 
The throughput factor is calculated on the basis of the assumed annual throughput of the $800 \mathrm{tHM} / \mathrm{y}$ plant compared to La Hague throughput in 2006. The throughput factor is equal to:

$$
\mathrm{TF}=800 / 1015=78.8 \%
$$

In this calculation, the throughput factor is rounded up to: $\mathrm{TF}=80 \%$

The TF is applied to the following energy consumptions:

$>$ Process

$>$ Utilities

Table 4 provides the estimated energy consumption of the reference 800 tHM/y Recycling Plant based on applying the VF (42\%) and the TF (80\%) to the associated Recycle Plant systems/processes.

Table 4. Estimated Energy Consumption (800 tHM/y Recycling Plant)

\begin{tabular}{|l|c|c|}
\cline { 2 - 3 } \multicolumn{1}{c|}{} & La Hague 2006 & $\begin{array}{c}\text { 800tHM/y } \\
\text { Recycling Plant }\end{array}$ \\
\hline Recycled UNF (tHM/y) & 1015 & 800 \\
\hline Electricity Consumption (GWh/y) & 378 & 220 \\
\hline Thermal Energy Consumption (GWh/y) & 312 & 196 \\
\hline Total Energy Consumption (GWh/y) & 690 & 416 \\
\hline
\end{tabular}

Efforts are continuing to reduce energy consumption in La Hague plant. In addition, internal AREVA studies indicate that an optimized design of a new plant should lead to further reduction in operational energy consumption.

As discussed previously, a new 800 tHM/y Recycle Plant energy consumption will also be dependent on the selected site location (geographical location and climatic characteristics).

Estimated energy consumption for reference $800 \mathrm{tHM} / \mathrm{y}$ Recycle Plant: 416 GWh/y (81\% of total energy consumption of Recycle Center \& RepU Facilities)

\subsubsection{MOX FUEL FABRICATION PLANT}

This section presents the energy consumption of the MOX Fuel Fabrication Plant (Box 2 in Figure 2).

MELOX Energy Consumption Data

Table 5 shows the annual energy consumption and associated MOX fuel fabrication throughput for the MELOX Plant for years 2004 through 2009 [4]:

Table 5. MELOX Energy Consumption vs. Fuel Fabrication Throughput

\begin{tabular}{|l|c|c|c|c|c|c|}
\cline { 2 - 7 } \multicolumn{1}{c|}{} & $\mathbf{2 0 0 4}$ & $\mathbf{2 0 0 5}$ & $\mathbf{2 0 0 6}$ & $\mathbf{2 0 0 7}$ & $\mathbf{2 0 0 8}$ & $\mathbf{2 0 0 9}$ \\
\hline Fabricated MOX Fuel (tHM/y) & 122 & 145 & 145 & 125 & 126 & 134 \\
\hline Electricity Consumption (GWh/y) & 37 & 36.6 & 37.6 & 38.5 & 38.1 & 38.5 \\
\hline Thermal Energy Consumption (GWh/y) & 6.4 & 5.9 & 5.7 & 4.8 & 5.6 & 3.6 \\
\hline Total (GWh/y) & 43.4 & 42.5 & 43.3 & 43.3 & 43.7 & 42.1 \\
\hline
\end{tabular}


As shown in Table 5, the electrical energy consumption is very stable from one year to another. The energy consumption is primarily dependent on the design of the building (ventilation, cooling) since the process equipment used to fabricate the MOX fuel is constantly maintained under operational conditions.

The fossil fuel (thermal energy) consumption, which is primarily used to heat the buildings, varies according to the yearly climatic conditions. This is reflected in the thermal energy consumption for years 2007 and 2009 in which the meteorological conditions were unusually mild which resulted in lower thermal energy consumption.

\section{Energy Calculation for the $\mathbf{8 0 0}$ tHMly Reference Plant}

The associated MOX Fuel Fabrication Plant for the referenced 800 tHM/y Recycle Center is composed of one building with a yearly manufacturing capacity of $100 \mathrm{tHM} / \mathrm{y}$ MOX Fuel. Since a conceptual layout of a $100 \mathrm{tHM} / \mathrm{y}$ MOX Fabrication Plant is not available (building size, equipment layout, etc.), this EROI analysis is based on the actual energy consumption data for the MELOX plant - total energy consumption of approximately $43 \mathrm{GWh} / \mathrm{y}$. This is a conservative assumption since the MELOX energy consumption data correlates with MOX fabrication capacity between $122 \mathrm{tHM} / \mathrm{y}$ and $145 \mathrm{tHM} / \mathrm{y}$. This assumption will not significantly impact the EROI calculation since the MOX Fabrication Plant energy consumption only represents approximately $8 \%$ of the total energy consumption for the Recycle Center.

Estimated energy consumption for $100 \mathrm{tHM} / \mathrm{y}$ MOX Fuel Fabrication Plant is $43 \mathrm{GWh} / \mathrm{y}$ (8\% of total consumption of Recycle Center \& RepU Facilities)

\subsection{REPU FACILITIES}

\section{Energy Consumption Data}

The energy consumption estimates related to RepU facilities are based on a combination of actual energy consumption data and results from actual process studies for facilities currently under development by AREVA. Operational energy consumption data is available for RepU fuel fabrication and is used in this EROI calculation. At the current time, AREVA does not operate or have access to actual energy consumption data for the RepU Conversion and Enrichment facilities. AREVA is currently designing/constructing equivalent RepU Conversion and Enrichment facilities in France.

$>$ EPICURE - AREVA RepU Conversion Facility (currently in design/construction phase)

$>$ Georges Besse II (GB II) - AREVA Centrifuge Enrichment Facility (currently ramping-up operations)

The energy consumption estimates provided below for the RepU Conversion and Enrichment facilities are based on the AREVA EPICURE and GB II energy consumption process studies correlated to the actual size of the RepU facilities to support a $800 \mathrm{tHM} / \mathrm{y}$ Recycle Center.

\subsubsection{REPU CONVERSION FACILITIES}

This section presents the energy consumption of the RepU Conversion facilities (Boxes 3, 4, 5, and 6 in Figure 2) as well as the denitration process that is located in the Recycling Plant (Box 1 in Figure 2). The estimated energy consumption for the RepU Conversion facilities given below is based on engineering process studies performed by AREVA associated with the development of the EPICURE RepU Conversion Facility. Below is a general description of the chemical process and the energy consumption estimate based on the AREVA studies (adjusted to account for facility size difference). 


\section{General Description - Chemical Process}

Uranyl nitrate (UO2(NO3)2) is converted to uranium hexafluoride (UF6) for use in enrichment operations. The main chemical transformations are:

$$
\begin{array}{ll}
\text { Denitration } & \mathrm{UO}_{2}\left(\mathrm{NO}_{3}\right)_{2} \rightarrow \mathrm{UO}_{3}+\mathrm{NO}+\mathrm{NO}_{2}+\mathrm{O}_{2} \\
\text { Reduction } & \mathrm{UO}_{3}+\mathrm{H}_{2} \rightarrow \mathrm{UO}_{2}+\mathrm{H}_{2} \mathrm{O} \\
\text { Hydrofluorination } & \mathrm{UO}_{2}+4 \mathrm{HF} \rightarrow \mathrm{UF}_{4}+2 \mathrm{H}_{2} \mathrm{O} \\
\text { Fluorination } & \mathrm{UF}_{4}+\mathrm{F}_{2} \rightarrow \mathrm{UF}_{6}
\end{array}
$$

Hydrofluorination to UF4 and fluorination to UF6 are the most energy consuming steps. Fluorination to UF6 is achieved by contact of fluorine gas (F2) with UF4. Fluorine is produced on site by electrolysis.

An additional energy consuming step is the incorporation of depleted uranium hexafluoride (DUF6) defluorination to uranium oxide (U3O8) according to the following equations:

$$
\begin{aligned}
& \mathrm{UF}_{6}+\mathrm{H}_{2} \mathrm{O} \rightarrow \mathrm{UO}_{2} \mathrm{~F}_{2}+4 \mathrm{HF} \\
& 3 \mathrm{UO}_{2} \mathrm{~F}_{2}+\mathrm{H}_{2}+2 \mathrm{H}_{2} \mathrm{O} \rightarrow \mathrm{U}_{3} \mathrm{O}_{8}+6 \mathrm{HF}
\end{aligned}
$$

\section{Energy Estimate for the RepU Conversion Facilities}

The estimated energy consumption for entire RepU chemical conversion process (fluorine production, fluorination to UF6, defluorination of DUF6) is approximately $36 \mathrm{GWh} / \mathrm{y}$ (21 GWh/y electrical + 15 $\mathrm{GWh} / \mathrm{y}$ thermal).

This estimate includes process energy consumption for all the RepU Conversion Facilities and the denitration process. Utility (HVAC) energy consumption is also included for all the RepU Conversion Facilities, except for the following processes.

$>$ The denitration utility energy consumption is included in the 800 tHM/y Recycling Plant (Box 1 in Figure 2) energy calculation

$>$ The electrolysis utility energy consumption is included in the Conversion \& Fuel Fabrication Plant (Box 8 in Figure 2) energy calculation

\section{Estimated energy consumption for RepU chemical processing: $36 \mathrm{GWh} / \mathrm{y}$ (7\% of total consumption of Recycle Center \& RepU Facilities)}

\subsubsection{REPU ENRICHMENT}

This section presents the energy consumption for enriching the RepU in a NatU enrichment facility (Box 7 in Figure 2).

\section{Energy Consumption Data}

The following energy consumption estimate is based on energy requirements for enriching the RepU from the reference $800 \mathrm{tHM} / \mathrm{y}$ Recycle Center in a centrifuge enrichment facility. Operational energy consumption data for the RepU Enrichment Facility (centrifuge technology) is not available within the AREVA Group. The estimated energy consumption for the RepU Enrichment given below is based on engineering process studies performed by AREVA associated with the design \& startup of the Georges Besse II Enrichment Plant (centrifuge technology).

\section{Energy Calculation for Enriching the RepU from the Recycle Center}

This analysis assumes that the enrichment of the U235 content of UF6 from $0.76 \%$ to $5 \%$ is performed in an existing NatU enrichment plant using centrifuge technology. Enrichment of $748 \mathrm{tU} / \mathrm{y}$ would require a separative work unit of $0.34 x 106$ SWU/y and would yield 58.5 tU/y of enriched RepU and 689.5 tU/y 
of $0.4 \%$ depleted RepU.1 Only the electrical needs have been estimated as the thermal needs are almost negligible compared to the electrical ones [5].

The calculation for determining the required SWU is described in the following paragraphs.

A generalized enrichment element can be treated as a "black box" into which flows material of a certain isotopic composition and out of which flow two steams, one containing a higher percentage and the other a lower percentage of the desired isotope than was present in the feed stream.

Separative Work per Unit (SWU) is calculated according to the following equation:

$$
\mathrm{SWU}=[\mathrm{P} * \mathrm{~V}(\mathrm{xp})+\mathrm{W} * \mathrm{~V}(\mathrm{xw})-\mathrm{F} * \mathrm{~V}(\mathrm{xf})]^{*} \mathrm{~T} \text { (Formula 1) }
$$

$\mathrm{T}=$ time

The symbols F, P, and $\mathrm{W}$ denote feed, product, and tails flow rates and are usually expressed in units such as kilograms per second $(\mathrm{kg} / \mathrm{s})$.

$V(x i)=(2 * x i-1) * \operatorname{Ln}[x i /(1-x i)]$, where the symbols $x p, x w$, and $x f$ refer to the percentage composition in numbers of molecules of the desired isotope $\left(\mathrm{U}^{235}\right)$ in the respective flow stream.

The 800 tHM/y Recycle Center yields an annual flow rate of $F=748$ tU with $\mathrm{xf}=0.76 \%$. The selected enrichments for Product and Tails are 5\% (xp) and 0.4\% (xw), respectively.

Product and Tails annual flow rates are calculated by mass balance on $\mathrm{U}^{235}$ :

$$
\mathrm{P}=58.5 \mathrm{tU} \text { and } \mathrm{W}=689.5 \mathrm{tU}
$$

By applying Formula 1 with T=1 year, the required SWU is calculated as 0.34x106 SWUs.

Based on the results of the GB II process studies, the energy consumption for enriching the RepU from a $800 \mathrm{tHM} / \mathrm{y}$ Recycle Center is $45 \mathrm{kWh} / \mathrm{SWU}$. As calculated previously, the RepU enrichment will require approximately $0.34 \times 106 \mathrm{SWU}$ which results in an annual enrichment facility energy consumption of 15 GWh (0.34x106 SWU x $45 \mathrm{kWH} / \mathrm{SWU})$. This estimate is in good agreement with published estimates for centrifuge technology. Table 6 shows the reference consumption data published in the URENCO sustainability reports.

Table 6. URENCO Enrichment Consumption Data

\begin{tabular}{|c|c|}
\hline Year & kWh/SWU \\
\hline 2006 & 42 \\
\hline 2007 & 40 \\
\hline 2008 & 39 \\
\hline 2009 & 37 \\
\hline
\end{tabular}

Estimated energy consumption for RepU enrichment: 15 GWh/y (3\% of total consumption of Recycle Center \& RepU Facilities)

\footnotetext{
${ }^{1}$ The separative work unit (SWU) carries units of mass and quantifies the degree of isotopic separation achieved. It is proportional to the feed mass as well as the energy requirement.
} 


\subsubsection{RepU FUEL FABRICATION}

This section presents the energy consumption for fabricating the RepU fuel in a NatU fuel fabrication facility (Box 8 in Figure 2).

\section{Energy Consumption Data}

Table 7 provides the direct energy consumption for $\mathrm{UO}_{2}$ production at the FBFC ROMANS [7]. The average energy consumption from 2005 to 2008 for average $\mathrm{UO}_{2}$ production of $865 \mathrm{tU} / \mathrm{y}$ (average) is:

Electricity - 30.8 GWh/y

$>$ Natural gas $-10.6 \mathrm{GWh} / \mathrm{y}$

Table 7. FBFC Romans Energy Consumption vs. Fabricated $\mathrm{UO}_{2}$ Throughput

\begin{tabular}{|l|c|c|c|c|}
\cline { 2 - 5 } \multicolumn{1}{c|}{} & 2005 & 2006 & 2007 & 2008 \\
\hline $\mathrm{UO}_{2}$ (tU/y) & 920 & 869 & 819 & 855 \\
\hline Electricity consumption (GWh/y) & 30.1 & 30.4 & 31.7 & 31.1 \\
\hline Natural gas consumption (GWh/y) & 12.5 & 8.4 & 10.8 & 10.8 \\
\hline Total (GWh/y) & 42.6 & 38.8 & 42.5 & 41.9 \\
\hline
\end{tabular}

\section{Energy Calculation for Fuel Fabrication in an Existing NatU Plant}

The energy consumption for a fuel fabrication plant to support the reference $800 \mathrm{tHM} / \mathrm{y}$ Recycle Center was calculated based the energy requirements for the FBFC plant. The required electrical and thermal energy in GWh/tU at FBFC was calculated and applied to a $58.5 \mathrm{tU} / \mathrm{y}$ RepU fuel fabrication.

A bottom-up calculation of the electrical needs based on chemical engineering assessments was also performed. The process incorporates both chemical and physical processing. Uranium hexafluoride is hydrolyzed and reduced to UO2 powder according to the following equations:

$$
\begin{aligned}
& \mathrm{UF}_{6}+\mathrm{H}_{2} \mathrm{O} \rightarrow \mathrm{UO}_{2} \mathrm{~F}_{2}+4 \mathrm{HF} \\
& \mathrm{UO}_{2} \mathrm{~F}_{2}+\mathrm{H}_{2} \rightarrow \mathrm{UO}_{2}+2 \mathrm{HF}
\end{aligned}
$$

The powder is then pelletized, sintered and loaded into fuel rods and assemblies. The most substantial energy consumption steps are hydrolysis, reduction and sintering.

On the basis of the FBFC ROMANS operational data for electrical consumption, the energy requirements for production of $58.5 \mathrm{tU} / \mathrm{y}$ is $2.1 \mathrm{GWh} / \mathrm{y}$. To verify this energy consumption value, a bottom-up calculation gives an electrical energy requirement of $2 \mathrm{GWh} / \mathrm{y}$ and confirms this calculation.

Similarly, on the basis of the FBFC ROMANS operational data, the natural gas consumption for the $58.5 \mathrm{tU} / \mathrm{y}$ is $0.7 \mathrm{GWh} / \mathrm{y}$. The natural gas is used primarily to heat facilities and operate limited plant components and is independent of product throughput.

Estimated energy consumption for enriched RepU fuel fabrication: $3 \mathrm{GWh} / \mathrm{y}$ ( $<1 \%$ of total consumption of Recycle Center \& RepU Facilities) 


\subsection{ENERGY INVESTMENT SUMMARY}

Table 8 summarizes the energy investment for both the Recycle Center (Recycling Plant and MOX Fuel Fabrication Plant) as well as the additional energy investment associated with the RepU facilities.

Table 8. Summary of Energy Investment During Operations

\begin{tabular}{|l|c|}
\hline \multicolumn{1}{|c|}{ Facility } & $\begin{array}{c}\text { Energy } \\
\text { Consumption } \\
\text { (GWh/y) }\end{array}$ \\
\hline Recycling Plant (Box 1 of Figure 2) & 416 \\
\hline MOX Fuel Fabrication Plant (Box 2 of Figure 2) & 43 \\
\hline Total Recycle Center (MOX Fuel Only) & 459 \\
\hline RepU Conversion Facility (Boxes 3, 4, 5, and 6 of Figure 2) & 36 \\
\hline RepU Enrichment Facility (Box 7 of Figure 2) & 15 \\
\hline RepU Fuel Fabrication Facility (Box 8 of Figure 2) & 3 \\
\hline Additional Incremental Energy Investment Due to RepU Fuel & 54 \\
\hline $\begin{array}{l}\text { TOTAL ENERGY INVESTMENT - } \\
\text { Both MOX (Recycle Center) + RepU Fuel }\end{array}$ & 513 \\
\hline
\end{tabular}

\subsection{ENERGY REQUIRED TO CONSTRUCT AND DECOMMISSION RECYCLING FACILITIES}

An estimate of the energy consumed during the construction and decommissioning of the recycling facilities depicted in figure 2 is summarized in Table 10 below supported by detailed calculations in Appendix A of this report. Construction energy calculations assumed a facility design similar to La Hague, but scaled to process 800 tHM/y. Decommissioning calculations were based upon published information from the West Valley Demonstration Project and the nu,bers should be considered as being very conservative in nature since they include numbers for waste specific to the West Valley Site that would not be found in a future recycling facility.

The energy consumed during the construction phase includes the energy used:

$>$ The production of the principal raw construction materials.

$>$ Refinement of those materials into useful forms.

$>$ Transportation.

$>$ Installation of the materials as part of the construction of the facilities.

$>$ The energy consumed during the dismantling phase includes the energy used.

$>$ Decommissioning and dismantling the facilities.

$>$ Transportation and disposal of the contaminated materials.

Energy consumption analysis only considered primary processes that are expected to be significant contributors to the total energy consumed during the construction and decommissioning phases of the Recycling Center Facilities and the RepU “Dedicated” Facilities.

Energy consumption for the extraction, transportation and manufacture of the buildinglequipment items is based on industry publications and experience from URS , and provides a reasonable approximation for use in determining the energy required to construct and dismantle the Recycling Center and the RepU "Dedicated" Facilities. 
Table 9. Summary of Energy Consumed, by Phase, Area and Type

\begin{tabular}{|l|c|c|c|c|c|c|c|}
\hline & \multicolumn{4}{|c|}{ Construction Phase } & \multicolumn{2}{c|}{ Decommissioning Phase } \\
\cline { 2 - 8 } & $\begin{array}{c}\text { Concrete } \\
\text { GWh }\end{array}$ & $\begin{array}{c}\text { Metallic } \\
\text { Elements } \\
\text { GWh }\end{array}$ & $\begin{array}{c}\text { Reinforcing } \\
\text { Steel GWh }\end{array}$ & $\begin{array}{c}\text { Excavation } \\
\text { GWh }\end{array}$ & $\begin{array}{c}\text { Electricity } \\
\text { GWh }\end{array}$ & $\begin{array}{c}\text { Natural } \\
\text { Gas GWh }\end{array}$ & $\begin{array}{c}\text { Diesel } \\
\text { GWh }\end{array}$ \\
\hline $\begin{array}{l}\text { Recycle Center } \\
\text { Facilities }\end{array}$ & 210.74 & 236.41 & 439.19 & 20.36 & 5198 & 9122 & 2479 \\
\hline $\begin{array}{l}\text { RepU } \\
\text { Processing } \\
\text { Facilities }\end{array}$ & 5.37 & 7.10 & 11.19 & 0.35 & 132 & 232 & 63 \\
\hline Total & 216.11 & 243.52 & 450.38 & 20.71 & 5331 & 9355 & 2542 \\
\hline
\end{tabular}

Total Energy consumed is approximately 18,000 GWh. If the recycling facilities are assumed to have an operating life of 50 years this will equate to an annual energy investment of $360 \mathrm{GWh} / \mathrm{y}$.

\subsection{FINAL ENERGY OUTPUT}

Both the MOX and the enriched RepU fuel are assumed to be loaded into existing LWRs. The 800 tHM/y Recycle Center will recover 100 t/y of MOX fuel and 59 t/y of RepU fuel. The thermal energy produced by the recycled fuel is the amount of each type of fuel multiplied by the discharge burn-up. The final energy produced is defined as electrical energy (energy provided to the grid). Typical net efficiency value for nuclear plants is 33\% (conversion of thermal energy to net electrical power available to the grid after deducting the electrical power required to operate the plant). Table 9 provides a summary of the energy (thermal and electrical energy) extracted from MOX and RepU fuel on an annual basis for an $800 \mathrm{tHM} / \mathrm{y}$ Recycle Center.

Table 10. Summary of Annual Energy Produced

\begin{tabular}{|l|c|c|c|c|}
\hline \multicolumn{1}{|c|}{ Fuel Type } & Tons/year & Burn-up, GWD/t & Thermal Energy, GWh/y & Electrical Energy, GWh/y \\
\hline MOX & 100 & 50 & $120,000^{(1)}$ & $39,600^{(2)}$ \\
\hline REPU & 59 & 50 & 70,800 & 23,400 \\
\hline Total & 159 & & 190,800 & 63,000 \\
\hline
\end{tabular}

(1) Thermal Energy Calculation: 100 t x 50 GWD/t x 24 h/D = 120,000 GWh/y

(2) Electrical Energy Calculation: 120,000 GWh/y x $0.33=39,600 \mathrm{GWh} / \mathrm{y}$ 


\subsection{EROI SUMMARY FOR ONE PASS RECYCLE SYSTEM}

Table 11 summarizes the EROI calculations for the operation of the Recycle Center and associated RepU facilities during the One Pass Scenario.

Table 11. EROI Calculations

\begin{tabular}{|l|c|c|c|}
\hline \multicolumn{1}{|c|}{ Fuel Type } & $\begin{array}{c}\text { Final Energy } \\
\text { Produced (GWh/y) } \\
\text { (ref. Table 10) }\end{array}$ & $\begin{array}{c}\text { Final Energy } \\
\text { Invested (GWh/y) } \\
\text { (ref. Tables 8 \& 9) }\end{array}$ & $\begin{array}{c}\text { EROI = Final Energy Produced } \\
\div \text { Final Energy Invested }\end{array}$ \\
\hline MOX Only & 39,600 & 459 & 86 \\
\hline RepU Addition & 23,400 & 54 & 433 \\
\hline Total MOX + RepU & 63,000 & 513 & N/A \\
\hline $\begin{array}{l}\text { Construction and } \\
\text { Decommissioning }\end{array}$ & N/A & $360^{*}$ & 72 \\
\hline $\begin{array}{l}\text { Total MOX + RepU } \\
\text { + Construction } \\
\text { And Decommissioning }\end{array}$ & 63,000 & 873 & \\
\hline
\end{tabular}

*Energy investment related to construction and decommissioning of the recycling facilities has been calculated as $360 \mathrm{GWh}$ per year assuming a 50 year lifetime.

\subsection{TWO PASS RECYCLE OPTION}

This section summarizes the results from Appendix B which considers the energy requirements and energy return for recycling of the used MOX and RepU, manufacturing it into new fuel and returning it for an additional irradiation in an LWR. To bound the number of times the used MOX and RepU can be recycled and placed back into an LWR it was determined that the characteristics of any new fuel manufactured must have similar performance in the reactor when compared to fresh UOx or the U/Pu content must stay within the current design parameters or regulations for fuel manufacture or shipment. The results of the study in Appendix B are shown in Table 12 below. Based upon the assumption that the used MOX and RepU from the one-pass system will form the basis for the feed to the recycle center an allowance must be made for the construction and decommissioning energy associated with recycling this material. 159 t UNF/800 t capacity x 360 (energy construction and D\&D) = 72 GWh/y

The total energy return for the combined One Pass and Two Pass Recycle Systems are presented in Table 13.

Table 12. Energy Consumed and Produced for the Two-Pass Recycle Option

\begin{tabular}{|l|c|c|}
\hline \multicolumn{1}{|c|}{ Fuel Type } & $\begin{array}{c}\text { Final Energy Produced, GWh/y } \\
\text { Ref. Appendix B, Table 3 }\end{array}$ & $\begin{array}{c}\text { Final EnergyConsumed, } \\
\text { GWh/y } \\
\text { Ref. Appendix B. Table 2 }\end{array}$ \\
\hline MOX Only & 19,800 & 76.9 \\
\hline RepU Total & 4,250 & 37.7 \\
\hline $\begin{array}{l}\text { Construction and Decommissioning } \\
\text { Associated with second pass. }\end{array}$ & N/A & 72 \\
\hline Total & 24,050 & 186.6 \\
\hline
\end{tabular}


Table 13. Complete Energy Return on Investment for Two-Pass Recycle

\begin{tabular}{|l|c|c|c|}
\hline \multicolumn{1}{|c|}{ Fuel Type } & $\begin{array}{c}\text { Final Energy } \\
\text { Produced } \\
\text { (GWh/y) } \\
\text { (ref. Tables 11 \& 12, } \\
\text { Appendix B) }\end{array}$ & $\begin{array}{c}\text { Final Energy } \\
\text { Invested } \\
\text { (GWh/y) } \\
\text { (ref. Tables 11 \& 12, } \\
\text { Appendix B ) }\end{array}$ & $\begin{array}{c}\text { EROI = Final Energy } \\
\text { Produced — Final Energy } \\
\text { Invested }\end{array}$ \\
\hline $\begin{array}{l}\text { One-Pass Recycle (Total MOX+ } \\
\text { RepU + Construction and } \\
\text { Decommissioning) }\end{array}$ & 63000 & 873 & 72 \\
\hline Two Pass Recycle & 24,050 & 186.15 & Not Applicable \\
\hline Total & 87,050 & 1059.15 & 82 \\
\hline
\end{tabular}

*Energy investment related to construction and decommission of the recycling facilities has been calculated as $360 \mathrm{GWh}$ per year assuming a 50 year lifetime

\subsection{RECYCLE OF THE USED FUEL FROM THE ONE-PASS RECYCLE SYSTEM INTO A SODIUM FAST REACTOR}

This section summarizes the results from Appendix $C$ which considers the energy requirements and energy return for recycling of the used MOX and RepU from the One Pass Recycle System. Thus, before the material gets to this point, it has already been burned in LWRs two times. All of the subsequent recycles would be conducted in 1100 MWe Sodium Fast Reactors (SFR) that are designed to consume $11.24 \mathrm{t} / \mathrm{y}$ of $\mathrm{Pu}$. Three conversion ratios were considered to give representative results of various possible fuel cycles. This is not a complete listing because there are many more possible fuel cycles that involve SFRs.

$>\mathrm{CR}<1$, (0.3) Burner reactor used to manage the Pu with only one pass through the SFR. The energy consumed and produced are shown in Table 14.

$>\mathrm{CR} \approx 1$, Break even reactor with the reactor producing as much $\mathrm{Pu}$ as it consumes. The results are shown in Table 15 for the initial pass through the SFR and each additional pass through the SFR.

$>\mathrm{CR}>1$ (1.2 Breeder reactor that produces additional Pu each cycle that is then manufactured into LWR MOX , to be burned one more time in LWRs. The results are shown in Table 16.

It should be noted that for a SFR to come to equilibrium on the Pu content in the fuel can take 9 to 10 passes through the reactor followed by recycle. Based upon AREVA's experience it is typical that the $\mathrm{Pu}$ loading in the fuel will increase by approximately $40 \%$ between the first and the ninth cycle. Appendix $\mathrm{C}$ details the results of this equilibrium cycle for each of the conversion ratios considered.

Table 14. Summary of Annual Energy Produced and Consumed in Fast Reactor Fuel Cycles for Burner SFR with CR $<1$

\begin{tabular}{|l|c|c|c|c|c|c|}
\hline SFR Fuel Cycle & $\begin{array}{c}\text { \% Pu } \\
\text { In SFR } \\
\text { MOX }\end{array}$ & $\begin{array}{c}\text { Fuel } \\
\text { Throughput, } \\
\text { t/y }\end{array}$ & $\begin{array}{c}\text { Number } \\
\text { of SFR } \\
\text { Required }\end{array}$ & $\begin{array}{c}\text { Discharge } \\
\text { Burnup, } \\
\text { GWD/t }\end{array}$ & $\begin{array}{c}\text { Energy } \\
\text { Produced, } \\
\text { GWhely }\end{array}$ & $\begin{array}{c}\text { Energy } \\
\text { Consumed, } \\
\text { GWhely }\end{array}$ \\
\hline One SFR Burn & 30.8 & $25.6^{*}$ & 2.3 & 68 & 16,700 & 94 \\
\hline
\end{tabular}

*Each SFR consumes 11.24 t/y of Pu 
Table 15. Summary of Annual Energy Produced and Consumed in Fast Reactor Fuel Cycles for Break Even SFR CR $\approx 1$

\begin{tabular}{|l|c|c|c|c|c|c|}
\hline \multicolumn{1}{|c|}{ SFR Fuel Cycle } & $\begin{array}{c}\% \mathrm{Pu} \\
\text { In SFR } \\
\text { MOX }\end{array}$ & $\begin{array}{c}\text { Fuel } \\
\text { Throughput, } \\
\text { t/y }\end{array}$ & $\begin{array}{c}\text { Number } \\
\text { of SFR's } \\
\text { Required }\end{array}$ & $\begin{array}{c}\text { Discharge } \\
\text { Burnup, } \\
\text { GWD/t }\end{array}$ & $\begin{array}{c}\text { Energy } \\
\text { Produced, } \\
\text { GWhely }\end{array}$ & $\begin{array}{c}\text { Energy } \\
\text { Consumed, } \\
\text { GWhe/y }\end{array}$ \\
\hline One SFR Burn & 16.35 & $48.4^{\star}$ & 4.3 & 100 & 46,400 & 104 \\
\hline Each Additional Burn & 22.7 & $48.4^{\star}$ & 4.3 & 100 & 46,400 & 46.0 \\
\hline
\end{tabular}

*Each SFR consumes $11.24 \mathrm{t} / \mathrm{y}$ of Pu

Table 16. Summary of Annual Energy Produced and Consumed in Fast Reactor Fuel Cycles for Breeder SFR CR $>1$

\begin{tabular}{|l|c|c|c|c|c|c|}
\hline \multicolumn{1}{|c|}{ SFR Fuel Cycle } & $\begin{array}{c}\text { \% Pu In } \\
\text { SFR } \\
\text { MOX }\end{array}$ & $\begin{array}{c}\text { Fuel } \\
\text { Throughput, } \\
\text { t/y }\end{array}$ & $\begin{array}{c}\text { Number } \\
\text { of SFR's } \\
\text { Required }\end{array}$ & $\begin{array}{c}\text { Discharge } \\
\text { Burnup, } \\
\text { GWD/t }\end{array}$ & $\begin{array}{c}\text { Energy } \\
\text { Produced, } \\
\text { GWhe/y }\end{array}$ & $\begin{array}{c}\text { Energy } \\
\text { Consumed, } \\
\text { GWhe/y }\end{array}$ \\
\hline One SFR Burn & 16.35 & $48.4^{\star}$ & 4.3 & 100 & $55,100^{1}$ & 105.5 \\
\hline Each Additional Burn & 22.7 & $48.4^{\star}$ & 4.3 & 100 & $55,500^{2}$ & 68.5 \\
\hline
\end{tabular}

*Each SFR consumes 11.24 t/y of Pu

1 Includes energy produced from UOx blankets.

2 Includes energy produced from LWR MOX.

\subsection{ENERGY REQUIRED TO BUILD AND DECOMMISSION SODIUM FAST REACTOR}

This section summarizes the calculations presented in Appendix D that estimate the energy consumed during the construction and decommissioning of a Generation IV Sodium Fast Reactor (SFR), Table 17. The calculations consider the energy consumed during the construction phase that includes the production of the principal raw construction materials, refinement of those materials into useful forms and installation of the materials as part of the construction of the SFR. The energy consumed during the dismantling phase that includes, decommissioning a SFR including dismantling and disposal of the contaminated materials.

The energy consumption for the extraction, transportation and manufacture of the building materials -concrete and reinforcing bars and subsequent decommissioning is based on industry publications and engineering experience, and provides a reasonable approximation for use in determining the energy required to construct and dismantle a SFR.

Table 17. Summary of Energy Consumed During Construction and Decommissioning of a SFR.

\begin{tabular}{|l|c|c|c|c|c|}
\hline \multirow{2}{*}{} & \multicolumn{2}{|c|}{ Construction Phase } & \multicolumn{3}{c|}{ Decommissioning Phase } \\
\cline { 2 - 6 } & $\begin{array}{c}\text { Concrete } \\
\text { GWh/Mwe }\end{array}$ & $\begin{array}{c}\text { Reinforcing } \\
\text { Steel } \\
\text { GWh/Mwe }\end{array}$ & $\begin{array}{c}\text { Electricity } \\
\text { GWh/Mwe }\end{array}$ & $\begin{array}{c}\text { Natural Gas } \\
\text { GWh/Mwe }\end{array}$ & $\begin{array}{c}\text { Diesel } \\
\text { GWh/Mwe }\end{array}$ \\
\hline $\begin{array}{l}\text { Energy for 1100 } \\
\text { MWe Reactor }\end{array}$ & 40 & 198 & 138 & 241 & 66 \\
\hline
\end{tabular}

The total energy for construction and decommissioning of each 1100 MWe reactor required is

$$
40+198+138+241+66=683 \text { GWh per reactor }
$$


Total Energy consumed is approximately 683 GWh for each 1100 MWe SFR required. If the SFR has an assumed operating life of 50 years this will equate to an annual increase in the energy consumption during operation of the SFR of $14 \mathrm{GWh} / \mathrm{y}$ per reactor. The energy required to construct and decommission the SFR's required for each scenario is presented in Table 18. Total energy consumed for D\&D and construction is the sum of the number of reactors multiplied by the energy for construction and D\&D of one reactor.

For CR $<1$. there are 2.3 reactors required $* 14=33 \mathrm{GWh} / \mathrm{y}$ for this scenario for a year.

Table 18. Energy Required to Construct and Decommission SFR's

\begin{tabular}{|l|c|c|c|c|}
\hline \multicolumn{1}{|c|}{ SFR Fuel Cycle } & $\begin{array}{c}\text { Number of } \\
\text { SFRs } \\
\text { Required }\end{array}$ & $\begin{array}{c}\text { Energy Consumed } \\
\text { to Construct and } \\
\text { Decommission } \\
\text { GWh/y }\end{array}$ & $\begin{array}{c}\text { Energy } \\
\text { Consumed During } \\
\text { Operations, } \\
\text { GWh/y }\end{array}$ & $\begin{array}{c}\text { Total Energy } \\
\text { Consumed } \\
\text { GWh/y }\end{array}$ \\
\hline $\mathrm{CR}<1$, One SFR Burn & 2.3 & 33 & 94 & 127 \\
\hline $\mathrm{CR}=1$, One SFR Burn & 4.3 & 60 & 104 & 164 \\
\hline $\mathrm{CR}=1$, One Additional Burn & 4.3 & 60 & 46 & 106 \\
\hline $\mathrm{CR}>1$, One SFR Burn & 4.3 & 60 & 105.5 & 165.5 \\
\hline $\mathrm{CR}>1$, One Additional Burn & 4.3 & 60 & 68.5 & 128.5 \\
\hline
\end{tabular}

\subsection{TOTAL ENERGY RETURN ON INVESTMENT FOR THREE SFR RECYCLE SCENARIOS.}

Table 19 below details the EROI calculation for the One-Pass Recycle MOX and RepU cycle with subsequent recycle through the SFR for the 3 conversion ratio designs of SFR considered.

Table 19. Complete EROI Calculations for SFR Scenarios Considered in Report

\begin{tabular}{|l|c|c|c|}
\hline \multicolumn{1}{|c|}{ Fuel Cycle } & $\begin{array}{c}\text { Final Energy } \\
\text { Produced } \\
\text { (GWh/y) }\end{array}$ & $\begin{array}{c}\text { Final Energy } \\
\text { Invested } \\
\text { (GWh/y) }\end{array}$ & $\begin{array}{c}\text { EROI = Final } \\
\text { Energy Produced } \\
\text { Ｆinal Energy } \\
\text { Invested }\end{array}$ \\
\hline One-Pass Recycle (LWRs Only) & 63,000 & 873 & 72 \\
\hline One SFR Burn with CR<1 & 16,700 & 127 & Not Applicable \\
\hline One-Pass Recycle + One SFR Burn with CR <1 & 79,700 & 1,000 & 80 \\
\hline One SFR Burn with CR=1 & 46,400 & 164 & Not Applicable \\
\hline One-Pass Recycle + One SFR Burn with CR $=1$ & 109,400 & 1037 & 105 \\
\hline Each Additional SFR Burn with CR $=1$ & 46,400 & 106 & Not Applicable \\
\hline One-Pass Recycle + Two SFR Burns with CR $=1$ & 155,800 & 1,143 & 136 \\
\hline One SFR Burn with CR>1 & 55,100 & 165.5 & Not Applicable \\
\hline One-Pass Recycle + One SFR Burn with CR $>1$ & 126,000 & 1,038 & 109 \\
\hline Each Additional SFR Burn with CR $>1$ & 55,500 & 128.5 & Not Applicable \\
\hline One-Pass Recycle + Two SFR Burns with CR $>1$ & 168,600 & $1,166.5$ & 144 \\
\hline
\end{tabular}




\subsection{CONCLUSIONS}

The energy return on investment has been calculated for a number of fuel cycle scenarios and was based upon recycling of 800tHM of used UOx fuel that had been discharged from LWRs. No fresh material other than depleted uranium was added into any fuel cycle considered. The results are presented in Figure 4 below.

The use of the SFR for recycling UNF and extracting additional energy from the fuel offers many potential scenarios that could be considered, this report considers only a few options. However the calculations and results presented in the report and the appendices would allow additional calculations to be conducted for other scenarios.

The EROI is a useful figure of merit when considering future fuel cycles. As with any calculation the assumptions will drive the answers. In this report, where possible, the calculations have been based upon current engineering practices and real data. In areas where there was less data available a conservative engineering judgment was made and documented.

Figure 4 below depicts the EROI for varying fuel cycle scenarios. The One-Pass Recycle System, in which MOX and RepU are recycled back into LWRs, yields an EROI of 72. An additional recycle of the used MOX and RepU increases the EROI up to 80. The introduction of SFRs, however, would raise the possibility of a much higher EROI. One option would take the MOX from the One-Pass Recycle System and recycle it through a SFR twice, which would increase the EROI of the fuel cycle to 144.

One of the main drivers affecting the EROI calculation was the efficiency of the reactor system to convert the fuel to electrical energy. In the case of the LWR this was assumed to be 33\% and for the SFR 40\%. Fuel burn-up was set at current industry values for LWRs and at reasonable levels for the SFR. It is important to realize that the fuel burn-up and change out is driven by other factors within the reactor system such as scheduled maintenances and the requirement for zero fuel failure. Unduly high fuel burnups were considered unlikely to be achievable.

The EROI for the SFR has been capped for the purpose of this study after 2 cycles. Subsequent recycle of the used SFR fuel will increase the EROI. However there has never been any industrial scale multi recycle of SFR fuel conducted. For the fuel in the SFR to come to equilibrium can take 9 to 10 cycles through the reactor and subsequent recycle. There will be increasing process losses and associated degradation in the isotopics of the Pu used in the fuel. At each stage the Pu content will increase and by cycle 9 or 10 can be $40 \%$ higher than the original Pu content in cycle 1 . The calculations associated with the equilibrium fuel cycle for the SFR are presented in Appendix C of this report.

It is recommended that future work should consider a way to use the EROI as one of the figures of merit when considering future fuel cycles. 
Figure 4. Results of Energy Return on Investment for Scenarios Considered in This Report.

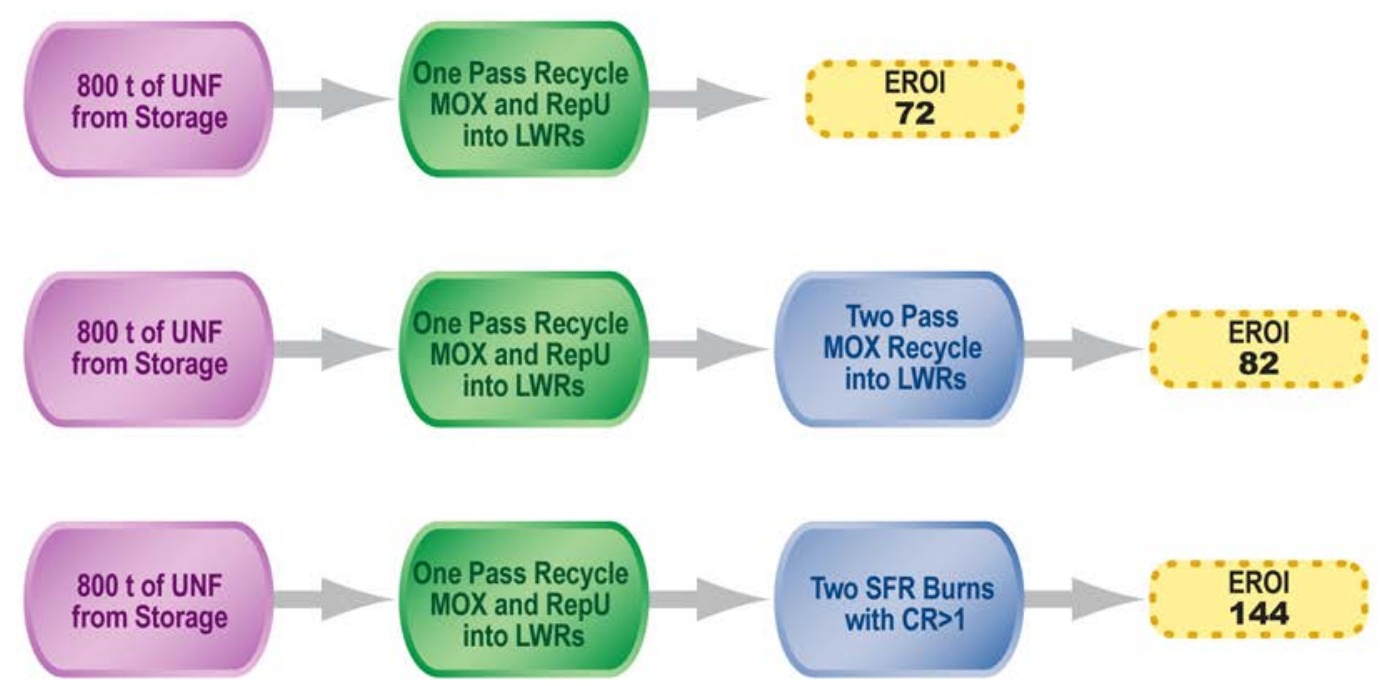

\subsection{REFERENCES}

1. World Nuclear Association, Energy Analysis of Power Systems (www.worldnuclear.org/info/inf11.html).

2. CFTC Conceptual Design Studies Final Report - AREVA Report Number: RPT 3000285.

3. Rapport environnemental, social et societal, AREVA NC établissement de La Hague années 2006 à 2009.

4. Rapport environnemental, social et societal, AREVA établissement de MELOX années 2006 à 2009.

5. Measures of the Environmental Footprint of the Front End of the Nuclear Fuel Cycle, E. Schneider, B.W. Carlsen, E. Tavrides, August 2010, NL/EXT-10-20652, FCRD-SYSA-2010000104.

6. Life cycle energy and greenhouse gas emissions of nuclear energy: A review. M. Lenzen, 2008, Energy Conversion and Management 49, 2178-2199.

7. Rapport environnemental, social et societal, établissement FBFC Romans année 2008. 


\section{Appendix A}

\section{EROI - Construction and Dismantling of Recycle Center and RepU Dedicated Facilities}




\section{INTRODUCTION}

This appendix provides an estimate of the energy consumed during the construction and decommissioning of an 800 tHM/yr Used Nuclear Fuel (UNF) Recycle Center, which comprises of the Recycling Center Facilities and the RepU “Dedicated” Facilities.

The energy consumed during the construction phase includes the energy used:

$>$ The production of the principle raw construction materials.

$>$ Refinement of those materials into useful forms.

$>$ Transportation

$>$ Installation of the materials as part of the construction of the facilities

The energy consumed during the dismantling phase includes the energy used:

$>$ Decommissioning and dismantling the facilities.

$>$ Transportation and disposal of the contaminated materials.

Energy consumption analysis will only consider primary processes that are expected to be significant contributors to the total energy consumed during the construction and decommissioning phase of the Recycling Center Facilities and the RepU “Dedicated” Facilities.

Energy consumption for the extraction, transportation and manufacture of the buildinglequipment items is based on industry publications and experience from URS , and provides a reasonable approximation for use in determining the energy required to construct and dismantle the Recycling Center and the RepU “Dedicated” Facilities.

The Energy Return on Investment (EROI) calculation is based on the Fuel Cycle diagram shown in, Figure 1:

Figure 1. Used Nuclear Fuel Recycle System

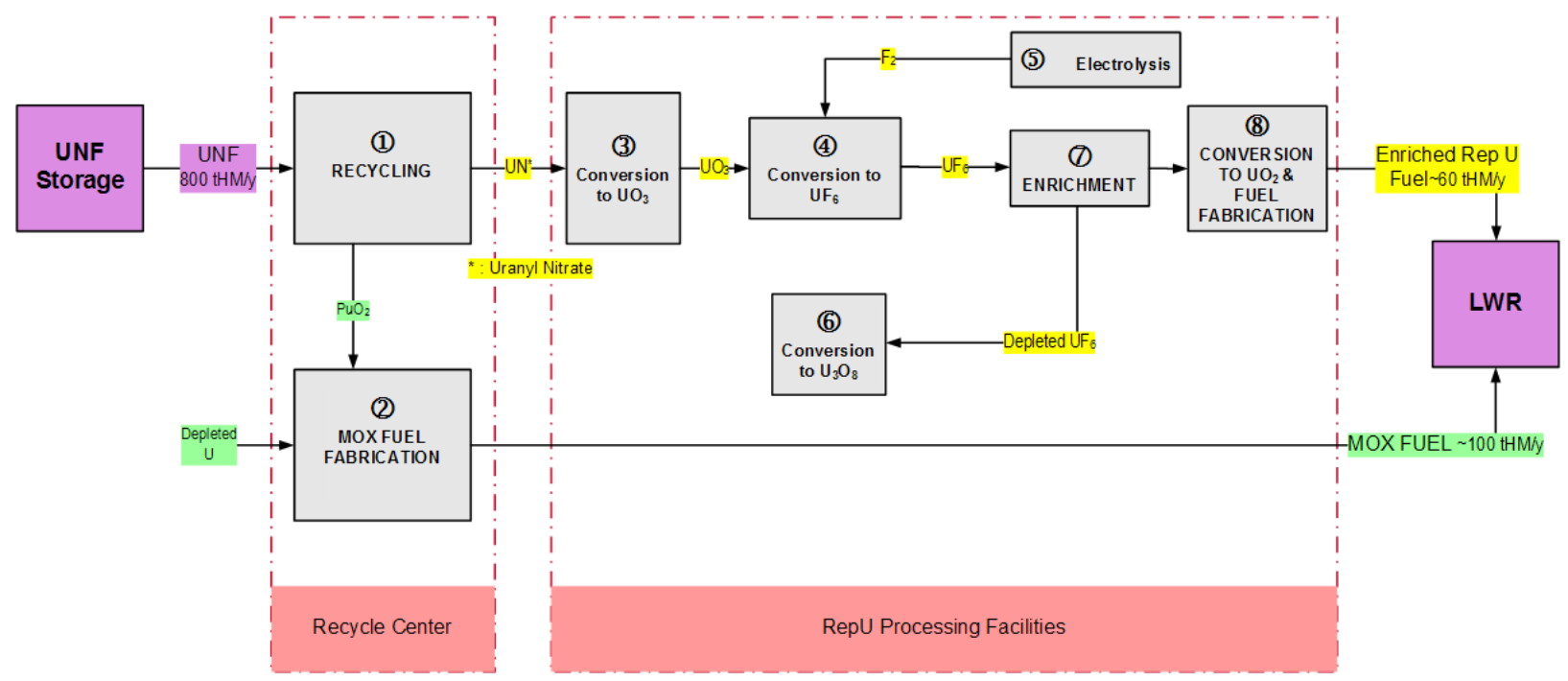


The Used Nuclear Fuel Recycle System includes:

$>$ Recycling Plant (Box 1 in Fig. 1)

- The recycle facility is assumed to be sized at $800 \mathrm{tHM} / \mathrm{y}$.

- Fuel Receipt and Storage Facility (FRS)

- Shearing/Dissolution/Compaction Facility (SDC)

- Separation/Purification/Concentration Facility (SPC)

- Fission Product Vitrification Facility (FPV)

- High Active Solid Waste Storage (HSS)

- Waste Treatment Facility (WTF)

- Administration, Utilities and Reagents Facility (AUR)

$>$ MOX Fuel Fabrication Facility (Box 2 in Fig. 1)

- MOX Fuel Fabrication Facility (MFFF)

$>$ RepU Processing Facilities (Box 3, 4 and 6 in Fig. 1)

- RepU “Dedicated” Facilities

\section{KEY ASSUMPTIONS}

The following Key Assumptions and Metrics are used:

$>$ Approximately $1 / 3$ of the building volumes is underground

$>$ Reinforcement steel is provided at $150 \mathrm{~kg}$ per cubic meter of concrete

$>$ Cableway is $\sim 2.5 \mathrm{~kg}$ per linear meter

$>38.6 \mathrm{MJ}$ per liter of diesel

$>35.0 \mathrm{MJ}$ per liter of gasoline

> 37.5 MJ per Cubic Meter of Natural Gas

\section{ENERGY CONSUMPTION}

Summary of Energy Consumed

Table 1. Summary of Energy Consumed, by Phase, Area and Type

\begin{tabular}{|l|c|c|c|c|c|c|c|}
\hline & \multicolumn{4}{|c|}{ Construction } & \multicolumn{3}{c|}{ Decommissioning } \\
\cline { 2 - 8 } & $\begin{array}{c}\text { Concrete } \\
\text { GWh }\end{array}$ & $\begin{array}{c}\text { Metallic } \\
\text { Elements } \\
\text { GWh }\end{array}$ & $\begin{array}{c}\text { Reinforcing } \\
\text { Steel GWh }\end{array}$ & $\begin{array}{c}\text { Excavation } \\
\text { GWh }\end{array}$ & $\begin{array}{c}\text { Electricity } \\
\text { GWh }\end{array}$ & $\begin{array}{c}\text { Natural } \\
\text { Gas } \\
\text { GWh }\end{array}$ & $\begin{array}{c}\text { Diesel } \\
\text { GWh }\end{array}$ \\
\hline $\begin{array}{l}\text { Recycle Center } \\
\text { Facilities }\end{array}$ & 210.74 & 236.41 & 439.19 & 1.38 & 5198 & 9122 & 2479 \\
\hline $\begin{array}{l}\text { RepU } \\
\text { Processing }\end{array}$ & 5.37 & 7.10 & 11.19 & 0.02 & 132 & 232 & 63 \\
\hline Facilities & 216.11 & 243.52 & 450.38 & 1.40 & 5331 & 9355 & 2542 \\
\hline Total & & & & & & & \\
\hline
\end{tabular}


The data used for the decommissioning estimates for the recycling facility were scaled from the published data for the decommissioning of the West Valley Demonstration Project (WVDP). The WVDP decommissioning scope did included more than the decommissioning of the recycle center facilities. As such the energy consumption data for decommissioning is very conservative and a degree of caution should be used for the data presented.

\section{Construction Materials Considered}

The following materials/work processes are included in the analysis:

$>4000$ psi concrete: Foundations, buildings

- Raw material production and transportation

- Batch-plant operations

- Transportation and installation

$>$ Metallic Elements: rebar, pipe, structural members, equipment, sheet product

- Raw material production and transportation

- Mill operations and transportation

- Secondary mills and fabrication

- Transportation and installation

$>$ Earthwork

- Excavation and backfill

\section{Construction Material Takeoffs}

The estimate of material quantities to construct the 800 tHM/yr Recycling Center Facilities and the RepU "Dedicated" Facilities were provided by the engineering division of AREVA (SGN). The estimates are based on actual decommissioning studies for AREVA's La Hague Recycling Plant and MELOX MOX Fuel Fabrication Plant, as well as detailed studies AREVA performed as part of the Global Nuclear Energy Partnership (GNEP) Program. The material quantities in this report have been scaled to represent the referenced $800 \mathrm{tHM} / \mathrm{yr}$ Recycle Center.

For each of the above Facilities, the quantity of concrete estimated for the foundations and buildings are reflected in Table 2. In addition to the concrete, an estimate for the mass of metallic elements are provided and reported in Table 3. Based on the provided metric of $150 \mathrm{~kg}$ of reinforcing steel per cubic meter of concrete, additional metallic quantities can be defined, in Table 4. Finally, the total site excavated volume for the entire area is provided at 756,967 cubic meters for the Recycle Center Facilities and 12,900 cubic meters for the RepU Processing Facilities. 
Table 2. Building Dimensions and Provided Quantities for Concrete in each Facility

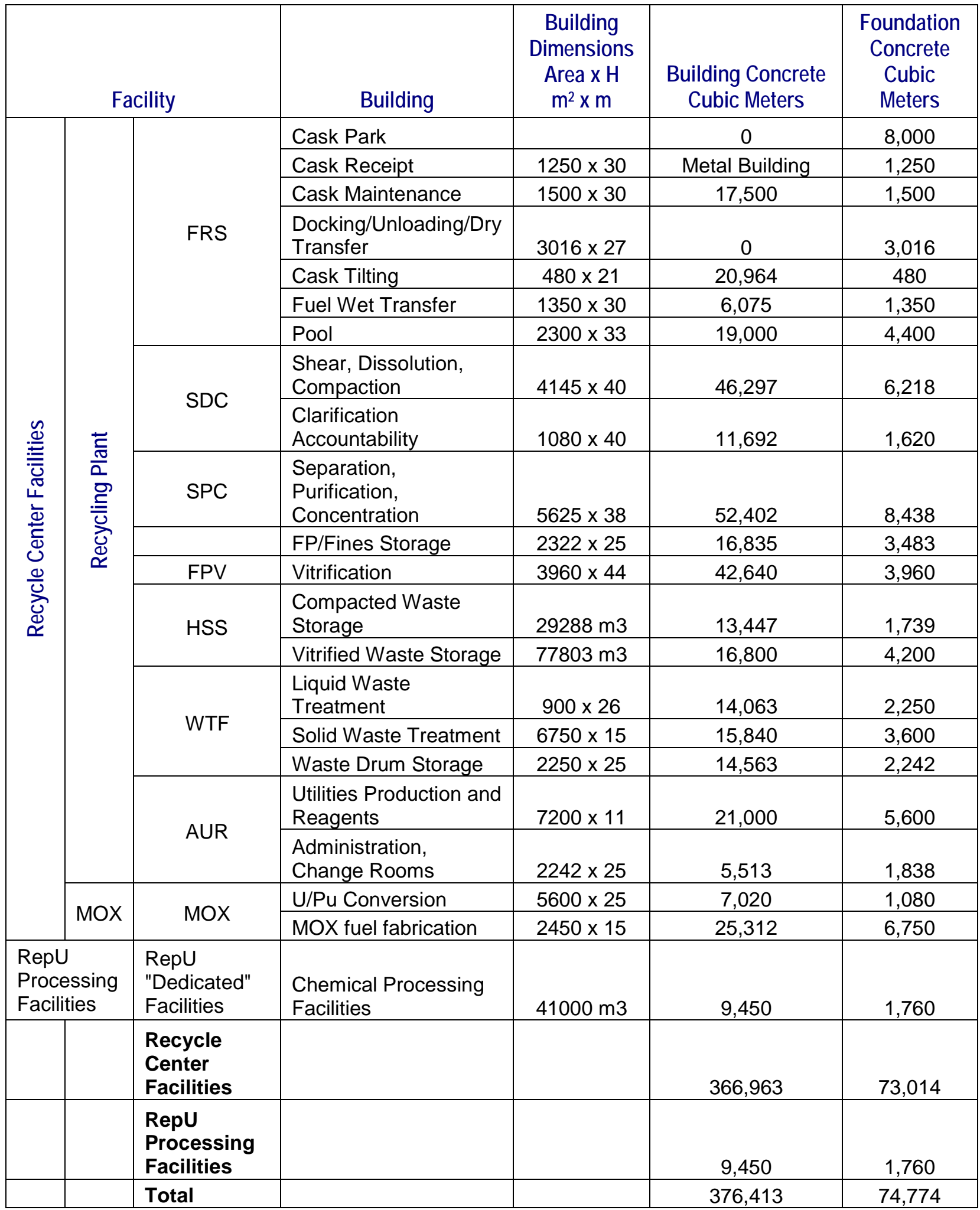


Table 3. Quantities of Metallic Components by Facility

\begin{tabular}{|c|c|c|c|c|c|c|c|c|c|}
\hline \multirow[b]{2}{*}{ Facility } & \multicolumn{4}{|c|}{ High Active Cells } & \multicolumn{5}{|c|}{ Low Active Cells } \\
\hline & $\begin{array}{l}\text { Equipment } \\
\text { tonnes }\end{array}$ & $\begin{array}{c}\text { Pipes } \\
\text { tonnes }\end{array}$ & $\begin{array}{l}\text { Liner, } \\
\text { Drip } \\
\text { Trays } \\
\text { tonnes }\end{array}$ & $\begin{array}{l}\text { Heavy } \\
\text { Steel } \\
\text { tonnes }\end{array}$ & $\begin{array}{l}\text { Equipment } \\
\text { tonnes }\end{array}$ & $\begin{array}{l}\text { Pipes } \\
\text { tonnes }\end{array}$ & $\begin{array}{l}\text { Framework } \\
\text { Tonnes }\end{array}$ & $\begin{array}{l}\text { Handling } \\
\text { Equipment } \\
\text { tonnes }\end{array}$ & $\begin{array}{c}\text { Cableway } \\
\text { tonnes }\end{array}$ \\
\hline FRS & 1439 & 702 & 369 & 108 & 909 & 156 & 580 & 857 & 55 \\
\hline SDC & 2558 & 355 & 126 & 949 & 553 & 151 & 143 & 145 & 94 \\
\hline SPC & 2105 & 1069 & 99 & 879 & 143 & 33 & 175 & 97 & 40 \\
\hline FPV & 855 & 234 & 65 & 755 & 362 & 69 & 132 & 261 & 84 \\
\hline HSS & 62 & 0 & 0 & 0 & 122 & 20 & 297 & 155 & 36 \\
\hline WTF & 1055 & 479 & 34 & 317 & 305 & 121 & 199 & 237 & 40 \\
\hline AUR & 0 & 0 & 0 & 0 & 839 & 109 & 190 & 10 & 33 \\
\hline MOX & 1849 & 77 & 9 & 51 & 2320 & 251 & 82 & 72 & 112 \\
\hline REPU & 298 & 88 & 21 & 92 & 167 & 27 & 54 & 55 & 15 \\
\hline $\begin{array}{l}\text { Recycle } \\
\text { Center } \\
\text { Facilities }\end{array}$ & 9923 & 2916 & 702 & 3059 & 5553 & 910 & 1798 & 1834 & 494 \\
\hline $\begin{array}{l}\text { RepU } \\
\text { Processing } \\
\text { Facilities }\end{array}$ & 298 & 88 & 21 & 92 & 167 & 27 & 54 & 55 & 14 \\
\hline Total & 10221 & 3004 & 723 & 3151 & 5720 & 937 & 1852 & 1889 & 508 \\
\hline
\end{tabular}


Table 4. Reinforcing Steel, at $150 \mathrm{~kg}$ per Cubic Meter of Installed Concrete

\begin{tabular}{|c|c|c|c|}
\hline Facility & Building & $\begin{array}{l}\text { Building Re- } \\
\text { Bar Tonnes }\end{array}$ & $\begin{array}{c}\text { Foundation } \\
\text { Re-bar Tonnes }\end{array}$ \\
\hline \multirow{7}{*}{ FRS } & Cask Park & 0 & 1,200 \\
\hline & Cask Receipt & 0 & 188 \\
\hline & Cask Maintenance & 2,625 & 225 \\
\hline & $\begin{array}{l}\text { Docking/Unloading/Dry } \\
\text { Transfer }\end{array}$ & 0 & 452 \\
\hline & Cask Tilting & 3,145 & 72 \\
\hline & Fuel Wet Transfer & 911 & 203 \\
\hline & Pool & 2,850 & 660 \\
\hline \multirow{2}{*}{ SDC } & $\begin{array}{l}\text { Shear, Dissolution, } \\
\text { Compaction }\end{array}$ & 6,945 & 933 \\
\hline & $\begin{array}{l}\text { Clarification } \\
\text { Accountability }\end{array}$ & 1,754 & 243 \\
\hline \multirow[t]{2}{*}{ SPC } & $\begin{array}{l}\text { Separation, Purification, } \\
\text { Concentration }\end{array}$ & 7,860 & 1,266 \\
\hline & FP/Fines Storage & 2,525 & 522 \\
\hline FPV & Vitrification & 6,396 & 594 \\
\hline \multirow[t]{2}{*}{ HSS } & $\begin{array}{l}\text { Compacted Waste } \\
\text { Storage }\end{array}$ & 2,017 & 261 \\
\hline & Vitrified Waste Storage & 2,520 & 630 \\
\hline \multirow{3}{*}{ WTF } & Liquid Waste Treatment & 2,109 & 338 \\
\hline & Solid Waste Treatment & 2,376 & 540 \\
\hline & Waste Drum Storage & 2,184 & 336 \\
\hline \multirow{2}{*}{ AUR } & $\begin{array}{l}\text { Utilities Production and } \\
\text { Reagents }\end{array}$ & 3,150 & 840 \\
\hline & $\begin{array}{l}\text { Administration, Change } \\
\text { Rooms }\end{array}$ & 827 & 276 \\
\hline \multirow{2}{*}{ MOX } & U/Pu Conversion & 1,053 & 162 \\
\hline & MOX fuel fabrication & 3,797 & 1,013 \\
\hline RepU "Dedicated" Facilities & $\begin{array}{l}\text { Chemical Processing } \\
\text { Facilities }\end{array}$ & 1,418 & 264 \\
\hline Recycle Center Facilities & & 55,044 & 10,952 \\
\hline RepU Processing Facilities & & 1,418 & 264 \\
\hline Total & & 56,462 & 11,216 \\
\hline
\end{tabular}




\subsection{CONSTRUCTION ENERGY CONSUMED-METRICS}

\subsubsection{CONCRETE PRODUCTION AND INSTALLATION}

Several research reports produced by the Athena Institute were utilized to provide an estimate of the energy required to produce, transport and install concrete 1, 2, and 3. The research was conducted for Canadian producers and users, but was broken into regions. Only the more densely populated regions (West and East Coast) were used to determine an aggregate metric. The Central and Prairie regions were not included due to exceedingly high transportation costs, and were considered inconsistent with the average U.S. population density. The breakdown of the energy consumed is identified in Table 5.

Table 5. Production and Transportation Energy Requirements of Concrete GJ per Cubic Meter

\begin{tabular}{|c|c|c|c|c|}
\hline & & & $\begin{array}{c}\text { Transportation } \\
\text { between batch } \\
\text { plant and site } \\
\text { and placement }\end{array}$ & Total Placed \\
\hline Extraction & Transportation & Processing & The \\
\hline 0.089 & 0.074 & 1.549 & 0.012 & 1.724 \\
\hline
\end{tabular}

Table 6 identifies that the bulk of the energy (89\% in this analysis) required to produce and place concrete lies in the processing. However, upon determination of the final site location, it may be necessary to recalculate the transportation energy. Note the batch plant distance in this case is set at $10 \mathrm{~km}$ from the site.

\subsubsection{METALLIC PRODUCTION AND INSTALLATION}

Due to the energy intense nature of the production of metal, there are a number of studies on which to draw metrics ${ }^{4}$, shown in Table 6.

Table 6. Energy per Step in Metallic Production by Metallic Elements, GJ per Tonne

\begin{tabular}{|l|c|c|c|c|c|c|c|}
\hline \multicolumn{1}{|c|}{ Metallic Elements } & Extraction & $\begin{array}{c}\text { Extraction } \\
\text { Transportation }\end{array}$ & Processing & $\begin{array}{c}\text { Primary } \\
\text { Mill }\end{array}$ & $\begin{array}{c}\text { Finishing } \\
\text { Mill }\end{array}$ & $\begin{array}{c}\text { Transportation } \\
\text { to Site and } \\
\text { Installation }\end{array}$ & $\begin{array}{c}\text { Total } \\
\text { Installed }\end{array}$ \\
\hline $\begin{array}{l}\text { Plate-Liner Sheets } \\
\text { Cableway }\end{array}$ & 2.59 & 0.63 & 18.83 & 4.27 & 1.00 & 0.63 & 27.95 \\
\hline Steel (rod) - rebar & 2.59 & 0.63 & 18.83 & 1.28 & 0.00 & 0.63 & 23.96 \\
\hline Tubing (pipes) & 2.59 & 0.63 & 18.83 & 4.27 & 2.31 & 0.63 & 29.26 \\
\hline Heavy Beams & 2.59 & 0.63 & 18.83 & 4.27 & 3.04 & 0.63 & 29.98 \\
\hline Framework (Joists) & 2.59 & 0.63 & 18.83 & 4.27 & 1.72 & 0.63 & 28.67 \\
\hline Fasteners & 2.59 & 0.63 & 18.83 & 1.28 & 8.96 & 0.63 & 32.91 \\
\hline Equipment* & 2.59 & 0.63 & 18.83 & 4.27 & 6.00 & 0.63 & 32.95 \\
\hline
\end{tabular}

*Values for the "Equipment" conformation were not included in the referenced reports, but are assumed values based on the complexity of the reported conformations. 
Note that the processing energy is again the bulk of the energy. In this case, the average processing energy is a cross section of both BOF (Blast Oxygen Furnace) type plants and EAF (Electric Arc Furnace). The average for the studies identified for BOF plants was 19 GJ per tonne, and the energy for EAF plants is closer to $8 \mathrm{GJ}$ per tonne. The industry is moving to the more efficient EAF process, but is still dominated by BOF facilities. Note also that the transportation to site is the same as the extraction transportation. This is due to the assumption that the averages established for the transportation of the raw materials, will extend to the average distance required to transport the finished product to the site from the mill. Note there was no specific correlation between the reported metallic elements and all of the categories established in the SGN information. In particular, "Equipment" and "Handling Equipment". Considering the complexity of the reported metallic elements, an assumption was made with respect to the "Finishing Mill” energy requirements.

\section{Excavation}

The final metric established is the energy required to excavate for the foundations. Nearly $1 / 3$ of each building is located underground, making the excavation portion of the project more significant than may be for other projects. There is limited published data for excavation energy requirements. However, the U.S. Department of Transportation utilizes a metric to adjust fixed price contracts for fluctuations in fuel prices $^{5}$, and publish these in gallons per cubic yard excavated (Table 7). Fuel usage factors for all excavation items include mobilization, clearing and grubbing, excavating, hauling, compacting and preparing the subgrade. Note the quantities described are for both diesel and gasoline and are to be taken in combination (diesel in equipment, and gasoline in support vehicles).

Table 7. Fuel Usage by Excavation Type, Gallons of Fuel per Cubic Yard

\begin{tabular}{|l|c|c|c|c|c|c|}
\hline \multirow{2}{*}{\multicolumn{1}{|c|}{ Excavation Type }} & \multicolumn{3}{c|}{ Diesel } & \multicolumn{3}{c|}{ Gasoline } \\
\cline { 2 - 7 } & Low & Avg. & High & Low & Avg & High \\
\hline Earth & 0.27 & 0.29 & 0.30 & 0.11 & 0.15 & 0.21 \\
\hline Rock & 0.37 & 0.39 & 0.42 & 0.17 & 0.18 & 0.22 \\
\hline Other & 0.33 & 0.35 & 0.38 & 0.15 & 0.16 & 0.18 \\
\hline
\end{tabular}

By utilizing the following conversions, the energy per cubic meter is determined, shown in Table:

38.6 MJ per liter of diesel

$>35.0 \mathrm{MJ}$ per liter of gasoline

Table 8. Excavation Energy Per Cubic Meter, MJ

\begin{tabular}{|l|c|c|c|c|c|c|}
\hline \multirow{2}{*}{\multicolumn{1}{|c|}{ Excavation Type }} & \multicolumn{3}{|c|}{ Diesel } & \multicolumn{3}{c|}{ Gasoline } \\
\cline { 2 - 7 } & Low & Avg. & High & Low & Avg & High \\
\hline Earth & 3.60 & 3.87 & 4.00 & 1.33 & 1.81 & 2.54 \\
\hline Rock & 4.94 & 5.20 & 5.60 & 2.06 & 2.18 & 2.66 \\
\hline Other & 4.40 & 4.67 & 5.07 & 1.81 & 1.94 & 2.18 \\
\hline
\end{tabular}

The average combined value of 6.55 MJ per cubic meter for the 3 excavation types will be used for this study. 


\section{CONSTRUCTION ENERGY CONSUMED - RESULTS}

Table 9. Energy Requirements for Installation of Concrete

\begin{tabular}{|l|c|c|c|}
\hline \multicolumn{1}{|c|}{ Facility } & Building Concrete GWh & Foundation Concrete GWh & Total Concrete GWh \\
\hline $\begin{array}{l}\text { Recycle Center } \\
\text { Facilities }\end{array}$ & 176 & 35 & 211 \\
\hline $\begin{array}{l}\text { RepU Processing } \\
\text { Facilities }\end{array}$ & 5 & 1 & 5 \\
\hline Total & 180 & 36 & 216 \\
\hline
\end{tabular}

Table 10. Energy Requirements for Fabrication and Installation of Rebar

\begin{tabular}{|l|c|c|c|}
\hline \multicolumn{1}{|c|}{ Facility } & Building Re-Bar GWh & Foundation Re-bar GWh & Total Re-bar GWh \\
\hline $\begin{array}{l}\text { Recycle Center } \\
\text { Facilities }\end{array}$ & 366 & 73 & 439 \\
\hline $\begin{array}{l}\text { RepU Processing } \\
\text { Facilities }\end{array}$ & 9 & 2 & 11 \\
\hline Total & 376 & 75 & 450 \\
\hline
\end{tabular}


Table 11. Energy Requirements for Fabrication and Installation of Various Metallic Components

\begin{tabular}{|l|c|c|c|c|c|c|c|c|c|}
\hline & \multicolumn{3}{|c|}{ High Active Cells } & \multicolumn{6}{c|}{ Low Active Cells } \\
\cline { 2 - 10 } & $\begin{array}{c}\text { Fquipment } \\
\text { GWh }\end{array}$ & $\begin{array}{c}\text { Pipes } \\
\text { GWh }\end{array}$ & $\begin{array}{c}\text { Lining, } \\
\text { Drip } \\
\text { Trays } \\
\text { GWh }\end{array}$ & $\begin{array}{c}\text { Heavy } \\
\text { Steel } \\
\text { GWh }\end{array}$ & $\begin{array}{c}\text { Equipment } \\
\text { GWh }\end{array}$ & $\begin{array}{c}\text { Pipes } \\
\text { GWh }\end{array}$ & $\begin{array}{c}\text { Framework } \\
\text { GWh }\end{array}$ & $\begin{array}{c}\text { Handling } \\
\text { Equipment } \\
\text { GWh }\end{array}$ & $\begin{array}{c}\text { Cableway } \\
\text { GWh }\end{array}$ \\
\hline $\begin{array}{l}\text { Recycle } \\
\text { Center } \\
\text { Facilities }\end{array}$ & 90.45 & 23.70 & 5.45 & 25.48 & 50.82 & 7.40 & 15.34 & 14.60 & 3.83 \\
\hline $\begin{array}{l}\text { RepU } \\
\text { Processing } \\
\text { Facilities }\end{array}$ & 2.73 & 0.72 & 0.16 & 0.77 & 1.53 & 0.22 & 0.43 & 0.44 & 0.11 \\
\hline Total & 93.18 & 24.42 & 5.61 & 26.24 & 52.35 & 7.62 & 15.77 & 15.04 & 3.95 \\
\hline
\end{tabular}

Table 12. Energy Requirements for Excavation

\begin{tabular}{|l|c|}
\hline \multicolumn{1}{|c|}{ Facility } & Excavation GWh \\
\hline Recycle Center Facilities & 20.36 \\
\hline RepU Processing Facilities & 0.35 \\
\hline Total & 20.71 \\
\hline
\end{tabular}




\section{DECOMMISSIONING MATERIALS CONSIDERED AND QUANTITY ESTIMATION}

In 1996, DOE submitted a preliminary Environmental Impact Statement (EIS) for the West Valley Demonstration Project6, a former fuel reprocessing and vitirification facility. This EIS was updated in 2007 and listed quantities of material to be decommissioned, and the energy requirements to complete the decommissioning, transportation and complete disposal. Key quantities identified in the EIS include:

$>$ Cubic meters of concrete

$>$ Tonnes of steel

$>$ Cubic meters of soil

$>$ Other Non-Hazardous

These identified quantities where utilized to scale the estimated energy requirements for the Recycling Center Facilities and RepU "Dedicated" Facilities decommissioning. The ratio of the total quantity of concrete between the WVDP and the three areas identified, were used to estimate the quantities of the soil and "Other non-hazardous".

Recycle Center Facilities: $\quad 439,977 / 61,280=7.18$

$>$ RepU Processing Facilities: $\quad 11,210 / 61,280=0.18$

The key quantities identified (concrete and steel) and the estimated quantities (soil and other nonhazardous) are identified in Table 12.

Table 13. Key Quantities for Determining Decommissioning Energy Requirements.

\begin{tabular}{|l|c|c|c|c|}
\hline \multicolumn{1}{|c|}{ Facility } & $\begin{array}{c}\text { Concrete Cubic } \\
\text { Meters }\end{array}$ & $\begin{array}{c}\text { Steel } \\
\text { Tonnes }\end{array}$ & $\begin{array}{c}\text { Soil Cubic } \\
\text { Meters }\end{array}$ & $\begin{array}{c}\text { Other Non-Hazardous } \\
\text { Cubic Meters }\end{array}$ \\
\hline $\begin{array}{l}\text { West Valley } \\
\text { Demonstration } \\
\text { Project }\end{array}$ & 61280 & 23800 & 1107000 & 140000 \\
\hline $\begin{array}{l}\text { Recycle Center } \\
\text { Facilities }\end{array}$ & 439,977 & 93,274 & 7948018 & 1005169 \\
\hline $\begin{array}{l}\text { RepU Processing } \\
\text { Facilities }\end{array}$ & 11,210 & 2,498 & 202504 & 25610 \\
\hline
\end{tabular}

\section{DECOMMISSIONING ENERGY CONSUMED - METRICS}

The EIS includes the electricity, natural gas and diesel fuel expected to be used to decommission the WVDP. These quantities are factored by the key quantities ratio determined above to estimate the quantities required for the Used Nuclear Fuel Recycling Center.

Table 14. Utility Requirements for Decommissioning

\begin{tabular}{|l|c|c|c|}
\hline \multicolumn{1}{|c|}{ Facility } & $\begin{array}{c}\text { Electricity MW- } \\
\text { Hrs }\end{array}$ & $\begin{array}{c}\text { Natural Gas } \\
\text { Cubic Meters }\end{array}$ & Diesel Liters \\
\hline West Valley Demonstration Project & 724,000 & $121,971,000$ & $32,204,000$ \\
\hline Recycle Center Facilities & 5198162 & $875,725,109$ & $231,217,678$ \\
\hline RepU Processing Facilities & 132442 & $22,312,254$ & $5,891,104$ \\
\hline
\end{tabular}


Converting these quantities to energy, utilizing the following conversions:

> $3600 \mathrm{MJ}$ per MW-Hr

37.5 MJ per Cubic Meter of Natural Gas

$>$ 38.6 MJ per Liter of Diesel

\section{DECOMMISSIONING ENERGY CONSUMED - RESULTS}

Table 15. Utility Requirements for Decommissioning

\begin{tabular}{|l|c|c|c|}
\hline \multicolumn{1}{|c|}{ Facility } & $\begin{array}{c}\text { Electricity } \\
\text { GWh }\end{array}$ & $\begin{array}{c}\text { Natural Gas } \\
\text { GWh }\end{array}$ & $\begin{array}{c}\text { Diesel } \\
\text { GWh }\end{array}$ \\
\hline West Valley Demonstration Project & 724.0 & $1,270.5$ & 345.3 \\
\hline Recycle Center Facilities & $5,198.2$ & $9,122.1$ & $2,479.2$ \\
\hline RepU Processing Facilities & 132.4 & 232.4 & 63.2 \\
\hline
\end{tabular}

Figure 2. Distribution of Estimated Energy Requirements of the Recycling Center Facilities during Construction - GWh

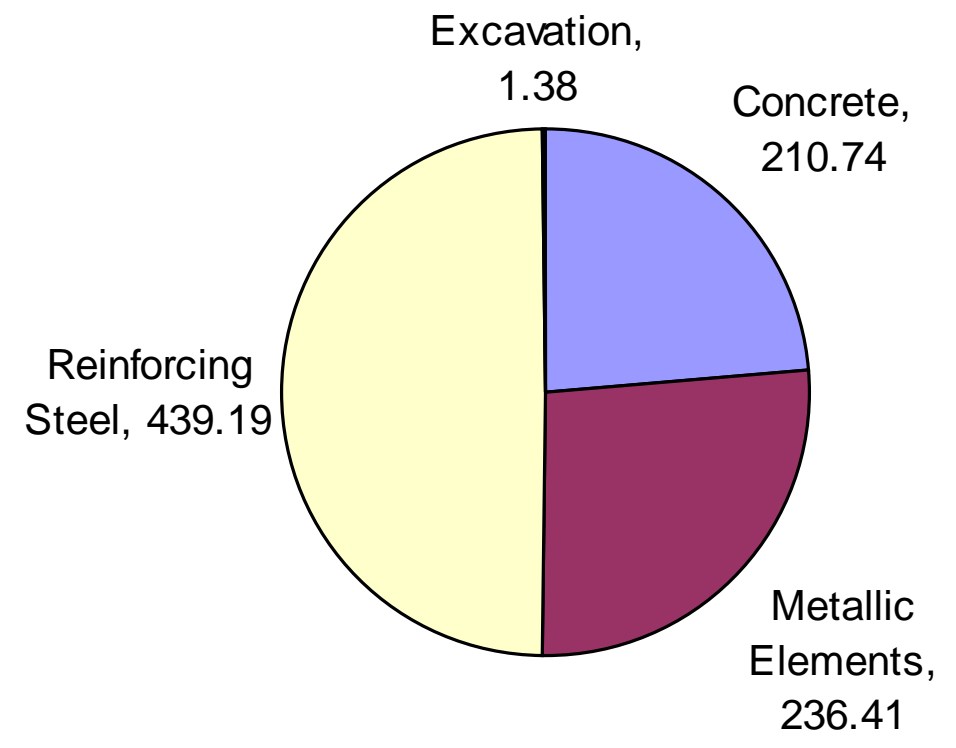


Figure 3. Distribution of Estimated Energy Requirements of the RepU Facilities during Construction - GWh

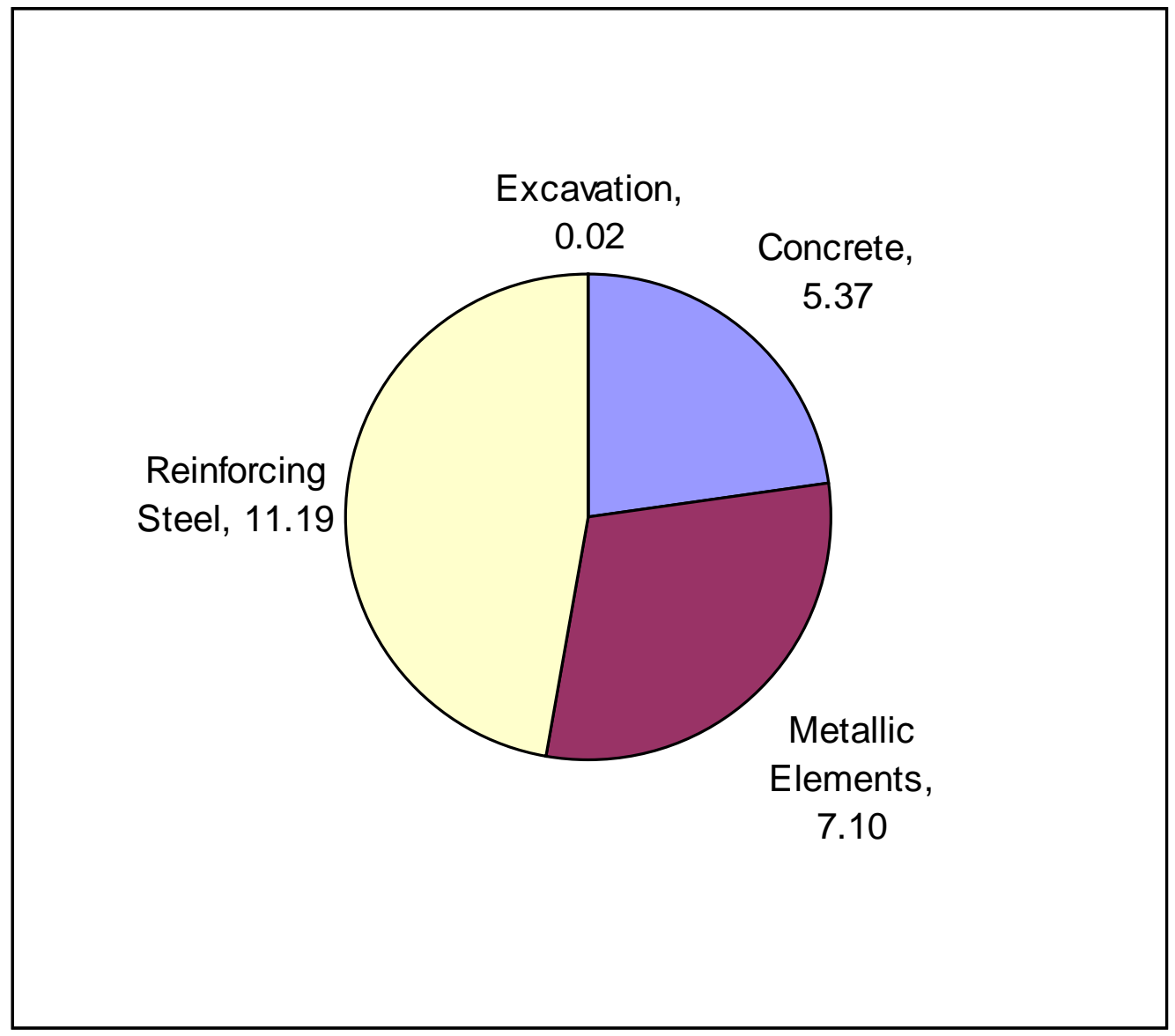


Figure 4. Distribution of Estimated Energy Requirements of the Recycling Center Facilities during Decommissioning - GWh

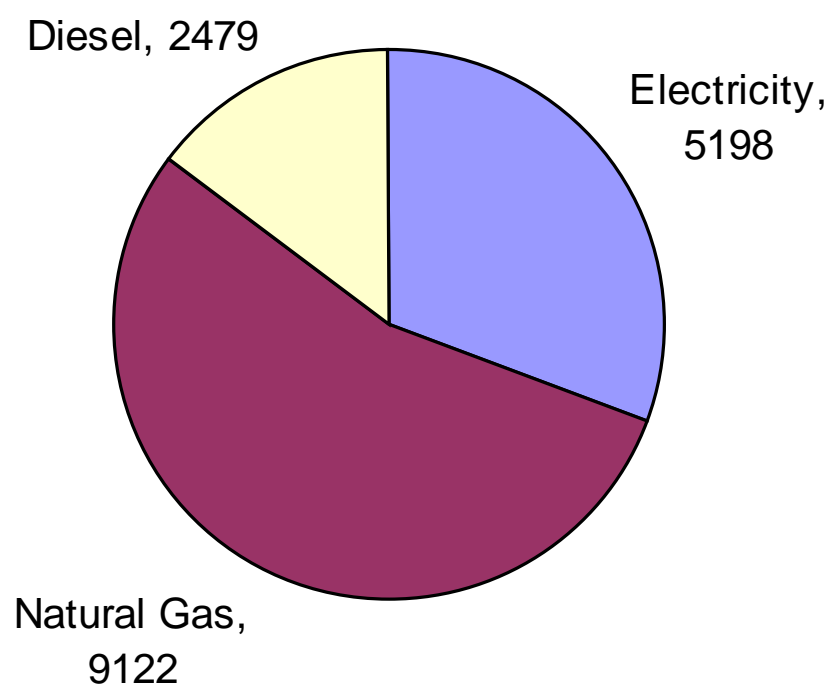


Figure 5. Distribution of Estimated Energy Requirements of the Recycling Center Facilities during Decommissioning - GWh

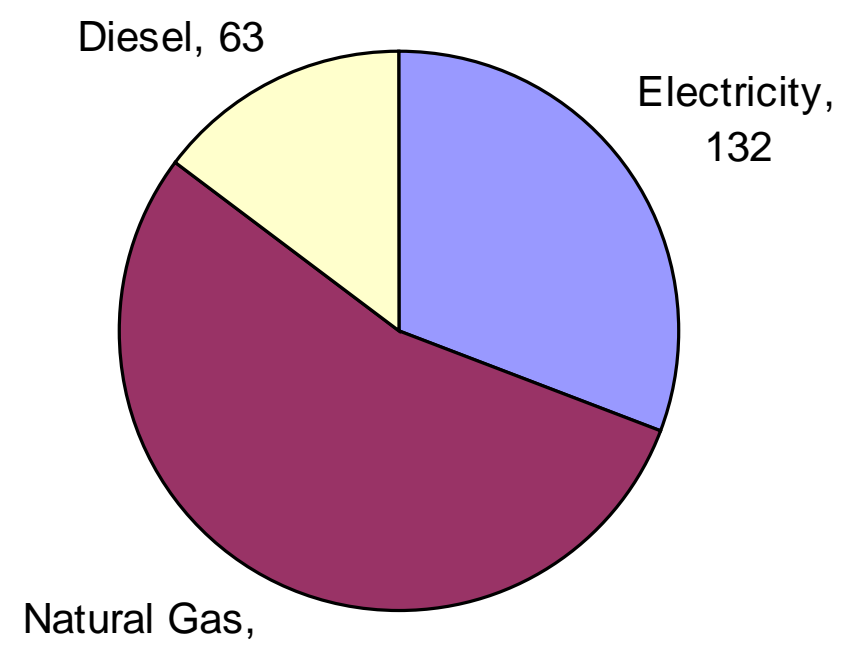

232 
Figure 6. Distribution of Estimated Energy Requirements of the Recycling Center Facilities during Construction and Decommissioning - GWh

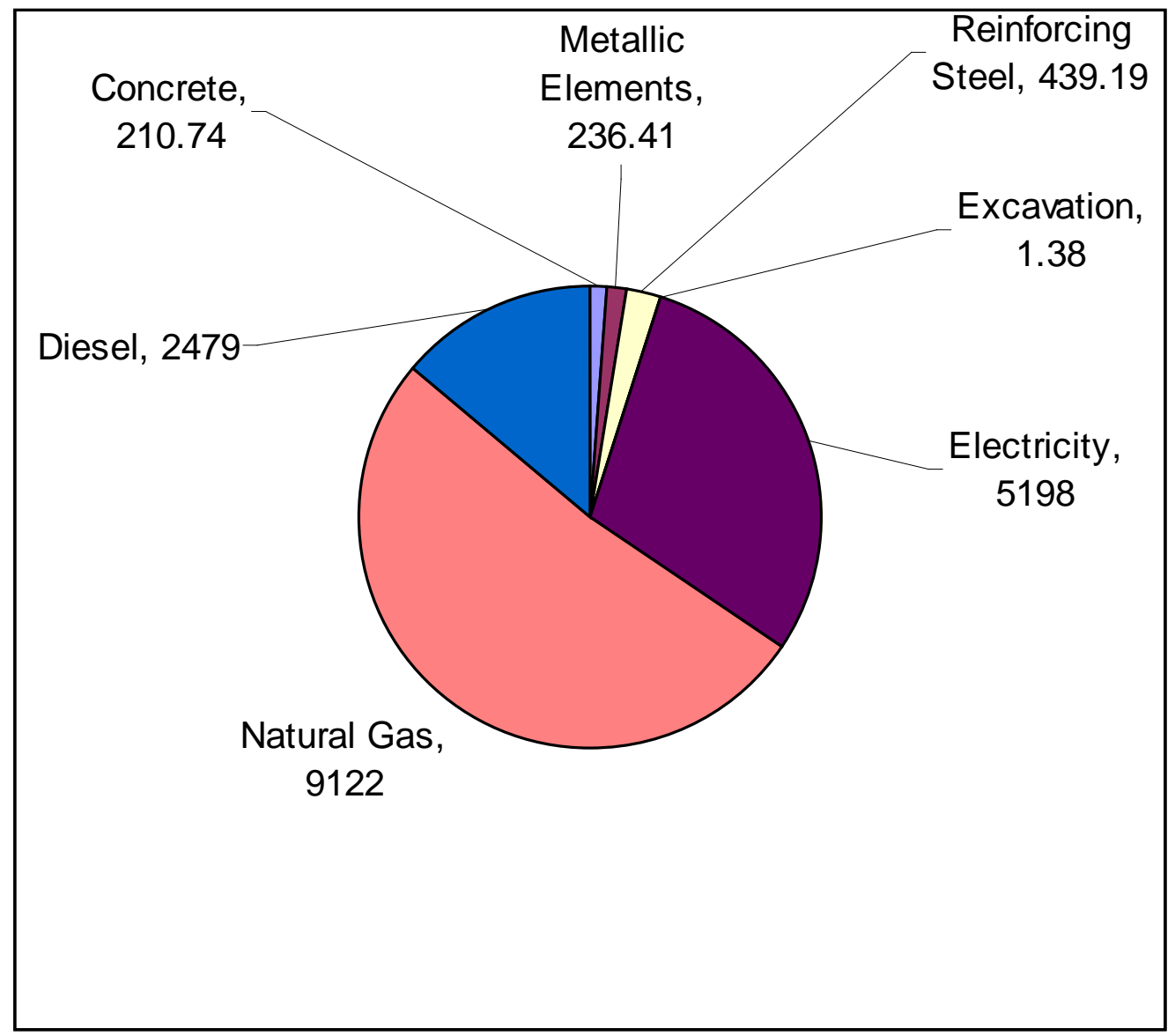


Figure 7. Distribution of Estimated Energy Requirements of the RepU Facilities during Construction and Decommissioning - GWh

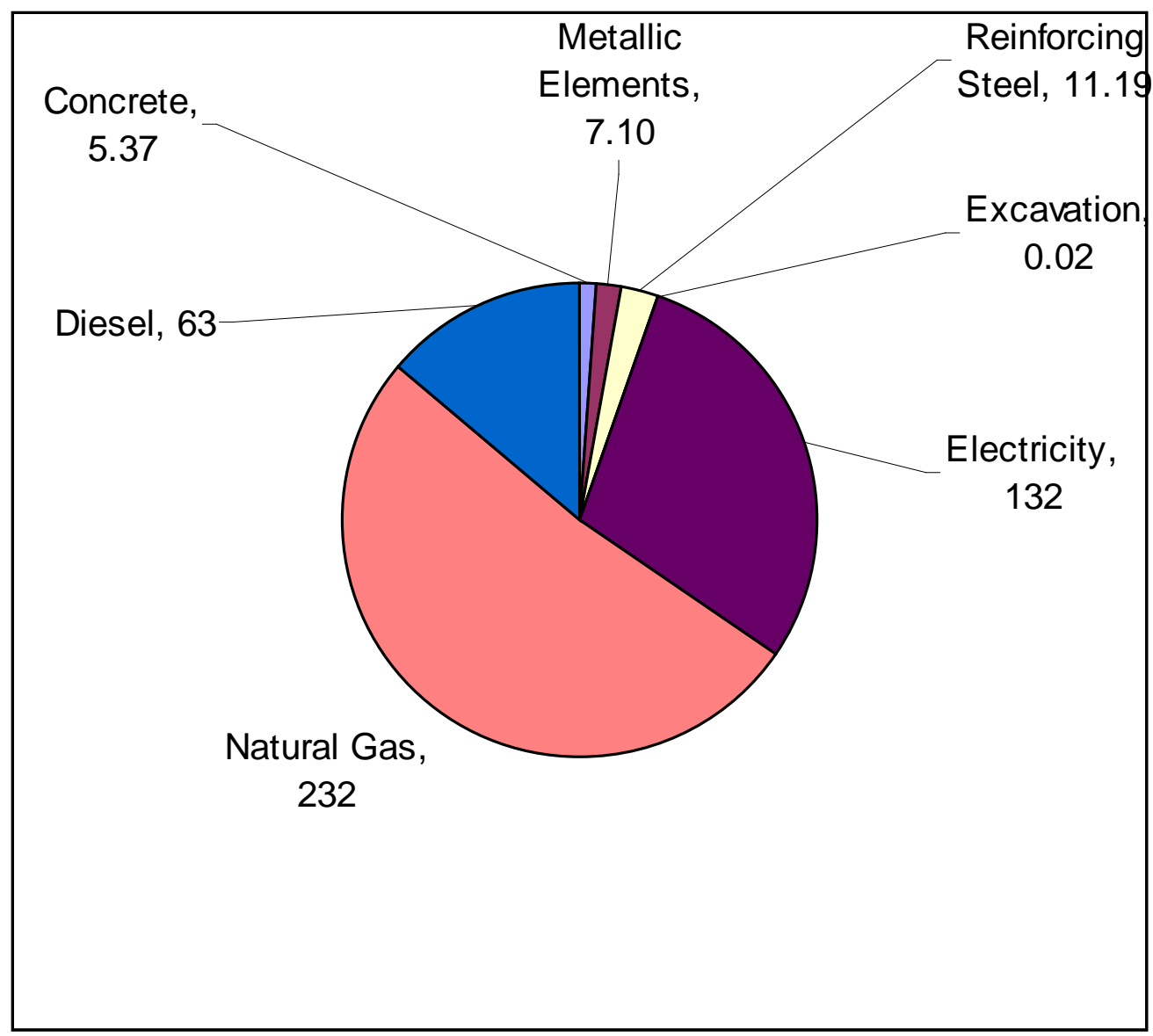


Figure 8. Distribution of Estimated Energy Requirements of the RepU Facilities during Construction and Decommissioning - GWh

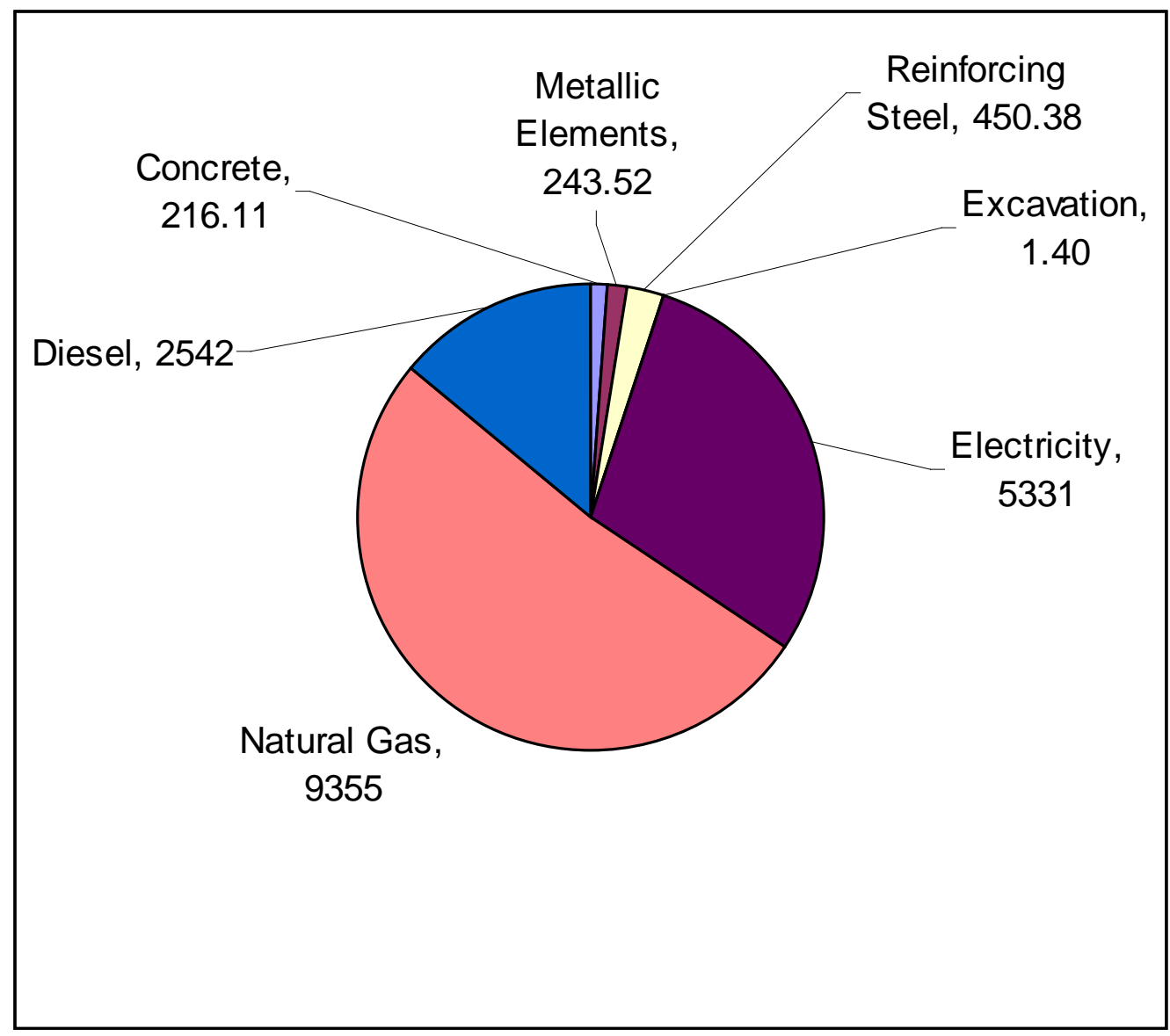




\section{REFERENCES}

1. ATHENA INSTITUTE CEMENT AND STRUCTURAL CONCRETE PRODUCTS: LIFE CYCLE INVENTORY UPDATE \#2 - 2005, OTTOWA.

2. CEMENT AND STRUCTURAL CONCRETE PRODUCTS: LIFE CYCLE INVENTORY UPDATE, PREPARED BY VENTA, GLASER \& ASSOCIATES, OTTAWA, CANADA, OCTOBER 1999.

3. RAW MATERIAL BALANCES, ENERGY PROFILES AND ENVIRONMENTAL UNIT FACTOR ESTIMATES: CEMENT AND STRUCTURAL CONCRETE PRODUCTS, PREPARED BY CANADA CENTRE FOR MINERAL \& ENERGY TECHNOLOGY AND RADIAN CANADA INC., OTTAWA, CANADA, OCTOBER 1993.

4. ATHENA INSTITUTE, CRADLE TO GATE LIFE CYCLE ANALYSIS INVENTORY: CANADIAN AND US STEEL PRODUCTION BY TYPE, MARKUS ENGINEERING RESOURCES, MARCH 2002.

5. U.S. DEPARTMENT OF TRANSPORTATION, FEDERAL HIGHWAY ADMINISTRATION, DEVELOPMENT AND USE OF PRICE ADJUSTMENT CONTRACT PROVISIONS, DATE: DECEMBER 10, 1980: HTTP://WWW.FHWA.DOT.GOV/PROGRAMADMIN/CONTRACTS/TA50803.CFM ACCESSED 5/1/11.

6. FINAL ENVIRONMENTAL IMPACT STATEMENT FOR DECOMMISSIONING AND/OR LONG-TERM STEWARDSHIP AT THE WEST VALLEY DEMONSTRATION PROJECT AND WESTERN NEW YORK NUCLEAR SERVICE CENTER - TABLES 4-3, 4-61. 


\section{Appendix B}

\section{Two-Pass Recycle System}




\subsection{INTRODUCTION}

In the main body of the report, Energy Return on Investment (EROI) was calculated for the Mixed Oxide (MOX) and Reprocessed Uranium (RepU) fuel fabricated from the recycling of used Light Water Reactor (LWR) Uranium Oxide (UOx) fuel. This appendix details the calculations related to the useful energy that can be extracted from the used MOX and RepU fuel if it goes through additional recycling, fuel fabrication and subsequent irradiation in an LWR. To bound the number of times the used MOX and RepU can be recycled and placed back into an LWR it was determined that the characteristics of any new fuel manufactured must have similar behavioral performance in the reactor when compared to fresh UOx or the U/Pu content must stay within the current design parameters or regulations for fuel manufacture or shipment.

For the purpose of this study it is assumed that the fuel cycle facilities described in Section 2 of the main body of the report, and depicted in Figure 1 are capable of recycling used MOX and RepU and that no new fuel cycle facility is required. Recycling of large quantities of used MOX has been demonstrated by AREVA at LaHague on a scale of the order of tens of tonnes of material per year. A complete mass balance for the One-Pass and Two-Pass Recycle Systems are depicted in Figure 2.

\subsection{KEY ASSUMPTIONS}

$>$ The existing fuel cycle facilities used for the recycling of UOx fuel would be adequate for the recycle of used MOX and RepU and the subsequent manufacture of new MOX and RepU fuel assemblies.

$>$ Any fuel assembly that was produced by recycling must have the same operational characteristics in a reactor as a standard fresh UOx fuel assembly design.

$>$ The isotopic concentration of $\mathrm{Pu}$ or $\mathrm{U}$ of any fuel assembly produced by recycle must be within the current operating design margins for current fuel cycle facilities.

- Less than 5\% enrichment for uranium based fuel.

- Less than $12.5 \%$ Pu content for MOX fuel

$>$ No blending of fresh UOx was considered to offset the isotopics of the second pass MOX or RepU.

$>$ The time taken to recycle used MOX and RepU is approximately the same as the time taken to recycle UOx fuel.

$>$ Pu loss associated with undissolved solids is assumed to be negligible for the purpose of this study.

\subsection{Two-Pass Recycle MOX}

Two-Pass Recycle MOX for the purpose of this report is defined as the MOX fuel that can be produced from the recycling of used MOX. This material has already been irradiated in an LWR two times, once as fresh fuel and once as MOX fuel. After its second pass through the recycle system, it will be burned a third time in an LWR.

The $100 \mathrm{t} / \mathrm{y}$ of used one-pass MOX fuel when recycled would produce $7.2 \mathrm{t} / \mathrm{y}$ of Pu for the second pass through the recycle system. At the maximum allowed manufacturing facility design loading of $12.5 \% \mathrm{Pu}$ in the heavy metal, this would allow the production of approximately $58 \mathrm{t} / \mathrm{y}$ of MOX fuel for the second pass.

The Pu obtained from recycling one-pass MOX will have less fissile content. Therefore two-pass MOX would only produce $43 \mathrm{GWD} / \mathrm{t}$ of thermal energy when placed in the LWR. 
The irradiation of Pu in an LWR results in a build-up of non-fissile isotopes of $\mathrm{Pu}$, which are not subsequently separated from the fissile Pu during the recycling of the used MOX. In order to manufacture new fuel from this one-pass Pu that has similar characteristics to the behavior of current UOx fuel in an LWR, the loading of Pu has to be increased to compensate for the non-fissile Pu present.

Previously modeled [1] One-Pass and Two-Pass LWR MOX fuel recycle systems were used as a basis for estimating the achievable discharge burn-up of the Two-Pass MOX recycle system. The first cycle used a Pu loading of $9.6 \% \mathrm{Pu}$ in the heavy metal to achieve a discharge burn-up of $50 \mathrm{GWD} / \mathrm{t}$. The second cycle would require a loading of $14.4 \%$ to achieve the same burn-up. In a MOX fuel fabrication plant the current design limit for Pu loading in a fuel assembly is $12.5 \%$. This operational limit of $12.5 \%$ for the Pu was used in the analysis presented here. Therefore, the discharge burn-up was decreased in proportion to the loading to derive the estimated (12.5/14.4) x $50=43 \mathrm{GWD} / \mathrm{t}$ burn-up.

In the absence of blending in fresh Pu into the head end of the recycling plant through the recycling of mixed batches of MOX and UOx fuel, recycling of batches of MOX fuel assemblies on their own can really only be conducted once. If the Pu is irradiated additional times, the limited amount of fissile material will not provide sufficient reactivity to allow it to be used in a fuel assembly for a LWR that behaves in the same manner as current UOx fuel. The discharge burn-up for the two-pass irradiation is reduced from $50 \mathrm{GWD} / \mathrm{t}$ to $43 \mathrm{GWD} / \mathrm{t}$. Further irradiation with discharge burn-ups lower than this may not be economical and therefore this possibility is not considered. 
Figure 1. Recycle of Used LWR Fuel in the Two-Pass Recycle System

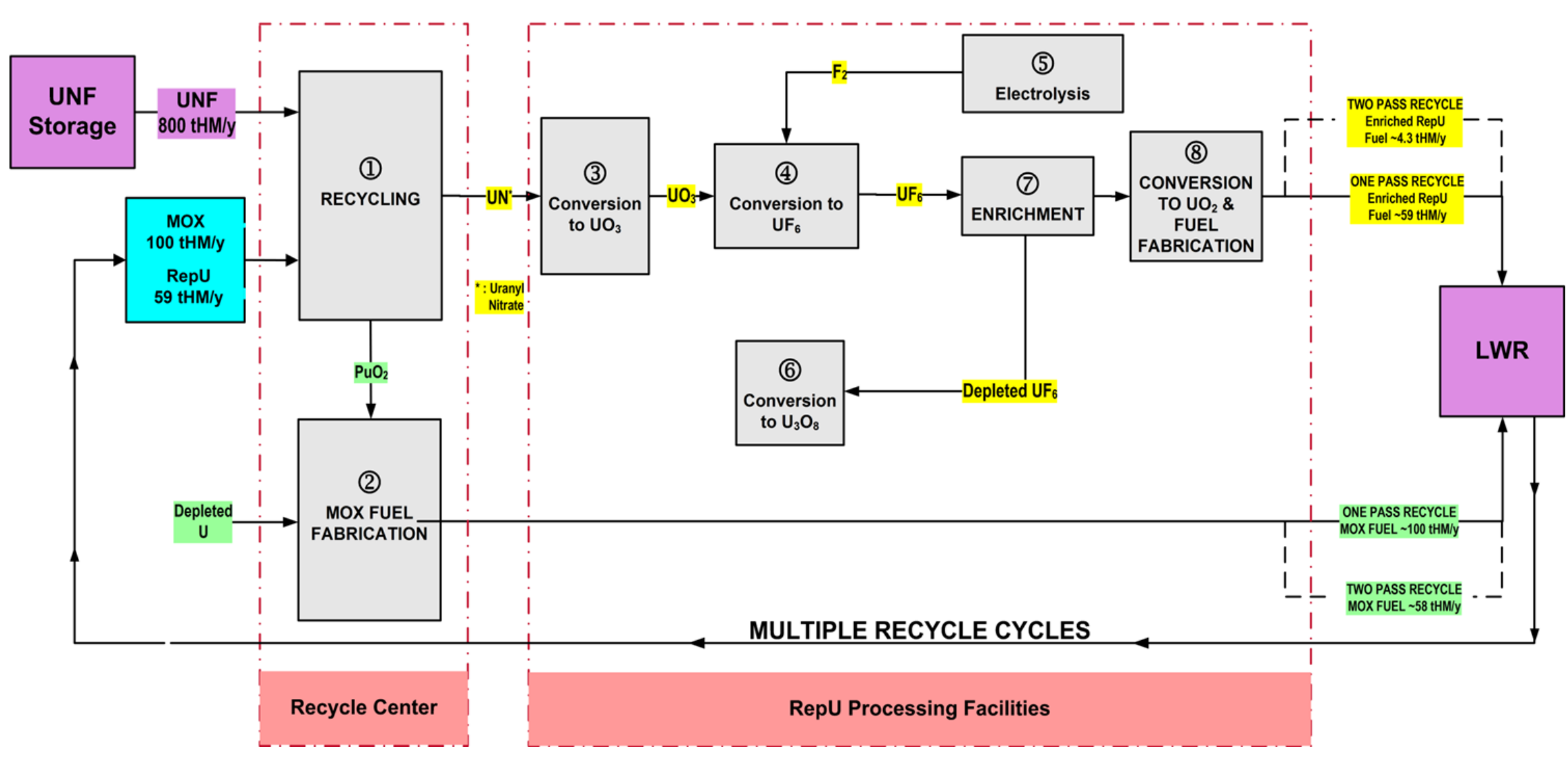




\subsection{Two-Pass RepU}

Two-Pass RepU for the purpose of this report is defined as the RepU fuel that can be produced from the recycling of used RepU. This material has already been irradiated in an LWR two times, once as fresh fuel and once as RepU fuel. After its second pass through the recycle system, it will be burned a third time in an LWR.

The $59 \mathrm{t} / \mathrm{y}$ of used Once-Through RepU fuel contains about 93.5\% uranium with an enrichment of 0.76 weight-percent U-235. This RepU is enriched to the present manufacturing, transport, and handling limit of $5 \%$. This produces $(59 * 0.935) *(0.0076-0.004) /(0.050-0.004)=4.3 \mathrm{t} / \mathrm{y}$ with a RepU tails enrichment of $0.4 \%$. With the increased U-236 content from the first pass through the recycle system, this fuel can achieve an estimated burn-up in the region of $40 \mathrm{GWD} / \mathrm{t}$.

Each irradiation cycle results in a build-up of U-236. The increasing amount of U-236, a non-fissile isotope, will require an increasingly higher U-235 enrichment to compensate and produce the required excess reactivity to achieve the necessary discharge burn-up in an LWR. The first irradiation of RepU requires an increase in enrichment of about 0.9 w/o U-235, putting the fuel at $5 \%$ enrichment. The second irradiation would require an even higher enrichment of about $6 \%$ to achieve the same discharge burn-up of $50 \mathrm{GWD} / \mathrm{t}$. Since the current limit for fuel transportation, manufacturing, handling, and storage is $5 \%$, the enrichment for the two-pass RepU is set to $5 \%$ enrichment and the achievable discharge burn-up is estimated by the amount of fissile burned. This yields a discharge burnup for two-pass recycled RepU at $5 \mathrm{w} / 0$ of $50 . \mathrm{x}(5.0-0.76) /(6.0-0.76)=40 \mathrm{GWD} / \mathrm{t}$.

A limiting factor for RepU is the fact that each subsequent recycle only produces a fraction of the fuel of the previous one due to the enrichment process. This quickly yields a small quantity of RepU which is economically unattractive to handle. For example, the initial 800 tonnes of UNF provides 59 tonnes of enriched RepU for the One-Pass RepU irradiation. The 59 tonnes of irradiated One-Pass RepU only yields about 4.3 tonnes of enriched RepU for the Two-Pass RepU irradiation. The third pass RepU irradiation will not have enough RepU fuel to fill a fuel assembly. Therefore, no further RepU recycling is considered.

It should also be noted that following the first pass through the recycle system, the RepU will contain approximately $0.7 \mathrm{t}$ of Pu that can be used to produce $7.3 \mathrm{t}$ of MOX fuel with $9.6 \%$ Pu content. Due to the isotopics of the Pu recovered this MOX fuel can reach burn-ups of $50 \mathrm{GWd} / \mathrm{t}$.

These assumptions are summarized in Table 1. 
Table 1. Summary of Key Assumptions for the Two-Pass Recycle System

\begin{tabular}{|l|c|}
\hline \multicolumn{1}{|c|}{ Parameter } & Assumed Value \\
\hline LWR Thermal Efficiency & $33 \%$ \\
\hline MOX Recycle & $100 \mathrm{t} / \mathrm{y}$ \\
\hline MOX recycled from First Pass Recycle & $58 \mathrm{t} / \mathrm{y}$ \\
\hline MOX produced for Second Pass Recycle & $7.2 \mathrm{t} / \mathrm{y}$ \\
\hline Pu in Two-Pass fuel & $12.5 \%$ \\
\hline Percent of Pu in Heavy Metal & \\
\hline Enrichment of uranium in MOX fuel & 0.25 w/o U-235 for U-tails \\
& 0.76 w/o U-235 for RepU \\
\hline Discharge Burn-up of MOX Two-Pass fuel & $43 \mathrm{GWD/t}$ \\
\hline RepU Recycle & 59 t/y \\
\hline RepU recycle from First Pass Recycle & $4.3 \mathrm{t} / \mathrm{y}$ \\
\hline RepU fuel produced for Second Pass & $0.76 \%$ \\
\hline Recycle & $0.4 \%$ \\
\hline Percent of U-235 in RepU & 5 w/o U-235 \\
\hline Percent of U-235 in RepU tails & $40 \mathrm{GWD/t}$ \\
\hline RepU Fuel Enrichment & $7.3 \mathrm{t} / \mathrm{y}$ \\
\hline Discharge Burn-up of RepU Two-Pass fuel & $9.6 \%$ \\
\hline MOX fuel produced & 0.76 w/o U-235 for RepU \\
\hline Percent of Pu in Heavy Metal & $50 \mathrm{GWD/t}$ \\
\hline Enrichment of uranium in MOX fuel & \\
\hline Discharge burnup of MOX Two-Pass fuel & \\
\hline & \\
\hline
\end{tabular}




\subsection{ENERGY CONSUMPTION}

The key Recycling Center facilities include the recycling facility, the MOX fuel manufacturing facility, the RepU conversion facility, the RepU enrichment facility, and the RepU fuel fabrication facility. These facilities are described in the main body of the Report. The energy consumed recycling both MOX and RepU are taken from Table 7 in the main body of the report and are summarized in Table 2.

Table 2. Summary of Annual Energy Consumption of the Two-Pass Recycle System

\begin{tabular}{|l|c|c|c|c|c|}
\hline & \multicolumn{2}{|c|}{$\begin{array}{c}\text { One-Pass Recycle System } \\
\text { (from Main Body of Report) }\end{array}$} & \multicolumn{2}{c|}{ Two-Pass Recycle System } \\
\cline { 2 - 3 } & $\begin{array}{c}\text { Fuel } \\
\text { Recycled } \\
\text { (t/y) }\end{array}$ & $\begin{array}{c}\text { Energy } \\
\text { Consumption } \\
\text { (GWh/y) }\end{array}$ & $\begin{array}{c}\text { Energy Per } \\
\text { Tonne } \\
\text { (GWh/t) }\end{array}$ & $\begin{array}{c}\text { Tonnes } \\
\text { Recycled or } \\
\text { Fabricated }\end{array}$ & $\begin{array}{c}\text { Energy } \\
\text { Consumption } \\
\text { (GWh/y) }\end{array}$ \\
\hline $\begin{array}{l}\text { Recycle Center (Box 1 in } \\
\text { Figure 2) }\end{array}$ & 800 & 416 & 0.520 & 100 & 52.0 \\
\hline $\begin{array}{l}\text { MOX Fabrication (Box 2 in } \\
\text { Figure 2) }\end{array}$ & 100 & 43 & 0.430 & 58 & 24.9 \\
\hline $\begin{array}{l}\text { RepU Recycle (Recovers U } \\
\text { and Pu) (Box 1 in Figure 2) }\end{array}$ & 800 & 416 & 0.520 & 59 & 30.7 \\
\hline $\begin{array}{l}\text { RepU Conv., Enr., \& } \\
\text { Fabrication (Boxes 3 - 8 in } \\
\text { Figure 2) }\end{array}$ & 59 & 54 & 0.915 & 4.3 & 3.9 \\
\hline $\begin{array}{l}\text { MOX (Pu from RepU) } \\
\text { Fabrication (Box 2 in Figure } \\
\text { 2) }\end{array}$ & 100 & 43 & 0.430 & 7.3 & 3.1 \\
\hline
\end{tabular}

The operational energy costs to recycle the $100 \mathrm{t} / \mathrm{y}$ of One-Pass MOX and the $59 \mathrm{t} / \mathrm{y}$ of One-Pass RepU are derived from the data for a facility with a nominal recycling capacity of 800 tUNF per year. Since the facilities work on a batch process the energy required to recycle the MOX and RepU batches can be approximated based upon the ratio of the recycle batch size compared to the initial $800 \mathrm{tHM} / \mathrm{y}$ figures. Similarly the energy required to fabricate the Two-Pass MOX fuel is estimated based upon the fabrication batch size ratio, as shown in Table 2. The energy to convert, enrich, and fabricate the RepU is approximated based on ratioing the energy for the 59t of RepU. This is a good approximation since the initial, final, and tails enrichments are the same for both cases.

Please note in the mass of used RepU and used MOX are combined to make a single batch of material to process through the recycle facility and the calculation above reflects this combination of RepU and MOX.

For example the energy required to recycle 100 tHM MOX is $(100 / 800) * 416=52 \mathrm{GWh} / \mathrm{y}$

\subsection{ENERGY PRODUCTION}

Both the MOX and the enriched RepU fuel are assumed to be loaded into existing LWRs. The Recycle Center, with a capacity of $800 \mathrm{tHM} / \mathrm{y}$, will recover approximately $100 \mathrm{t} / \mathrm{y}$ of MOX fuel and $59 \mathrm{t} / \mathrm{y}$ of RepU fuel for the first pass through the recycle system. The thermal energy produced by the recycled fuel is the amount of each type of fuel multiplied by the fuel's discharge burn-up, and this energy is converted to electrical energy that is sent to the electric grid. The overall reactor plant efficiency is assumed to be $33 \%$. The net electrical energy produced per year is provided in Table 3. 
Table 3. Summary of Annual Energy Produced in the Two-Pass Recycle System

\begin{tabular}{|l|c|c|c|c|}
\hline \multicolumn{1}{|c|}{ Fuel Type } & t/y & Burn-up, GWD/t & Thermal Energy, GWh/y & Electrical Energy, GWh/y \\
\hline MOX & 58 & 43 & 59,900 & 19,800 \\
\hline RepU-UOx & 4.3 & 40 & 4,130 & 1,360 \\
\hline RepU-MOX & 7.3 & 50 & 8,760 & 2,890 \\
\hline Total & 69.6 & --- & 72,790 & 24,000 \\
\hline
\end{tabular}

\subsection{SUMMARY}

Table 4 presents the calculation of the Energy Return on Investment for the Two-Pass Recycle System, using both MOX and RepU fuel. It should be noted that these numbers are comparable to those presented in the main body of this Report in that both sets of figures consider only the energy consumed in operations and do not include the energy required to construct and decommission the facilities.

The mass flow and energy balance for both the MOX and RepU options are also depicted in Figure 2.

Table 4. EROI Calculation for Twice-Through Cycles

\begin{tabular}{|l|c|c|c|}
\hline Fuel Type & $\begin{array}{c}\text { Final Energy } \\
\text { Produced, GWh/y } \\
\text { (ref. Table 3) }\end{array}$ & $\begin{array}{c}\text { Final Energy } \\
\text { Consumed, GWh/y } \\
\text { (ref. Table 2) }\end{array}$ & $\begin{array}{c}\text { EROI = Final Energy Produced } \div \\
\text { Final Energy Consumed }\end{array}$ \\
\hline MOX Only & 19,800 & 76.9 & $257^{\star}$ \\
\hline RepU Total & 4,250 & 37.7 & $113^{\star}$ \\
\hline Total & 24,000 & 114.6 & $210^{\star}$ \\
\hline
\end{tabular}

**The EROI calculation in this table does not include the energy consumed or produced by earlier recycle of the original 800 tHM of UOx Fuel used to produce the original feed material for this fuel cycle.

\subsection{REFERENCE}

1. Technical Report 39 - Core Design to Optimize Minor Actinide Burning, AREVA, RPT-30001162-000, April 2009. 
Figure 2. Mass Flow and Energy Balance

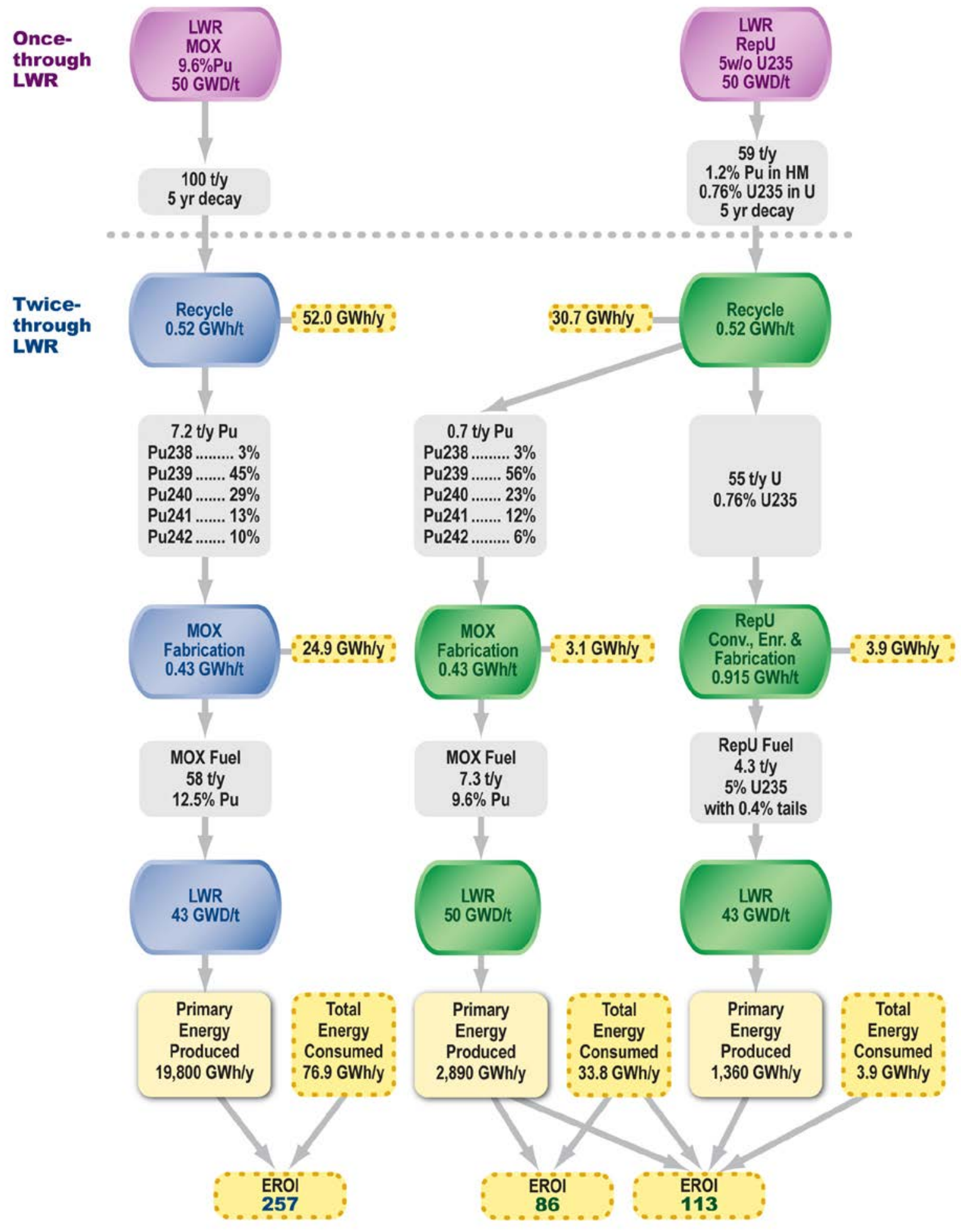




\section{Appendix C}

\section{Sodium Fast Reactor Recycle}




\subsection{INTRODUCTION}

In the main body of the report, Energy Return on Investment (EROI) was calculated for the Mixed Oxide (MOX) and Reprocessed Uranium (RepU) fuel fabricated from the recycling of used Light Water Reactor (LWR) Uranium Oxide (UOx) fuel that was placed back into an LWR for a further irradiation, One-Pass. Appendix A of this report conducted additional calculations that estimated the additional useful energy that could be extracted by further recycling of the used LWR MOX and LWR RepU fuel for a second time, Two-Pass, in an LWR. Recycling of the UNF for a third cycle was determined not to be practical in an LWR system based on the engineering requirements.

This appendix describes the calculations related to the useful energy that can be extracted from the used MOX and RepU fuel following the first irradiation cycle in an LWR with subsequent recycles being conducted in a sodium fast reactor (SFR). The calculations presented assume varying conversion ratio's (CR) in the SFR core and in the case of the breeder reactor, recycle of the excess Pu produced back into available LWR's.

For the purpose of this study it is assumed that the fuel cycle facilities described in Section 2 of the main body of the report, and depicted in Figure 1 are capable of recycling used fast reactor fuel and that no new fuel cycle facility is required. Recycling of large quantities of used fast reactor fuel has been demonstrated by AREVA at LaHague on a scale of the order of tens of tonnes of material per year.

\subsection{KEY ASSUMPTIONS}

$>$ All reactor core calculations are based upon an SFR of 1100 MWe generating capacity consuming approximately $11.24 \mathrm{t} / \mathrm{y}$ of Pu. The number of SFR's will vary based on the scenario considered.

$>$ The fuel cycles facilities for the SFR will be the same facilities used for LWR recycle.

- The recycle facility will be the same for the LWR UOx, RepU, LWR MOX and SFR MOX.

- The recycle facility is assumed to be sized at $800 \mathrm{tHM} / \mathrm{y}$.

$>$ It is assumed that the SFR and recycling facility will be collocated on the same site. No off site shipment of fuel.

$>$ For the case where the conversion ratio of the SFR is greater than 1, (Breeder reactor) NO additional SFR's will be required to manage the Pu produced each cycle by the SFR. The additional Pu produced will be utilized as LWR MOX into the existing LWR's. For one pass only in an LWR.

$>$ Energy required to manufacture SFR MOX will be approximately the same as LWR MOX manufacture.

$>$ The isotopic concentration of Pu for SFR MOX fuel assembly produced is relaxed so the facility can operate above $12.5 \%$ Pu concentration.

$>$ Time taken to recycle used SFR MOX is approximately the same as the time taken to recycle UOx, RepU and MOX fuel.

$>\mathrm{Pu}$ loss associated with un-dissolved solids during multiple recycle of SFR MOX or process losses during recycling of the SFR MOX is assumed to be negligible for the purpose of this study.

$>$ Conversation ratios and maximum fuel burn-ups for the SFR were chosen based on engineering expectations for realistic values.

$>$ SFR UOx manufacture has been assumed to be approximately the same as RepU manufacture as no enrichment is required. 


\subsection{BASIS OF MASS FLOW FOR PU AVAILABLE FOR SFR MOX RECYCLE}

The recycle facility is sized to process 800 metric tHM/y of spent LWR UNF per year. The initial calculations in the body of the main report showed that recycling 800 tHM of UOx fuel will produce 100 $\mathrm{t} / \mathrm{y}$ of MOX fuel and $59 \mathrm{t} / \mathrm{y}$ of RepU fuel which is then irradiated in an LWR. This $159 \mathrm{t}$ of used MOX and used RepU contains approximately $7.9 \mathrm{t}$ of Pu following the irradiation cycle. This evaluation assumes that the, $7.9 \mathrm{t} / \mathrm{y}$ of Pu is recycled and manufactured into MOX fuel for a fast reactor.

\subsection{FAST REACTOR CONVERSION RATIO}

The major factor influencing the fast reactor fuel cycles is the conversion ratio (CR).

The CR is the Pu production in the SFR reactor core divided by the Pu consumption in the reactor core. For the purpose of this report the following fuel cycle were considered.

$>\mathrm{CR}<1$, Burner reactor

$>\mathrm{CR} \approx 1$, Break even reactor

$>\mathrm{CR}>1$ Breeder reactor.

For each CR, both a One-Pass fuel cycle and a subsequent fuel recycle were examined. It should be noted that for a SFR to come to equilibrium on the Pu content in the fuel can take 9 to 10 passes through the reactor followed by recycle. Based upon AREVA's experience it is typical that the Pu loading in the fuel will increase by approximately $40 \%$ between the first and the ninth cycle.

The following sub-sections discuss the parameters assumed for each CR.

\subsubsection{CR < 1:-PU BURNER}

This fuel cycle represents a fast reactor core design that overall consumes more Pu during operations compared to the amount that of Pu it produces, that it would be used as an "actinide burner". A CR of $\approx 0.3$ [1] is selected to represent this class of fuel cycle. While this is not the smallest possible CR, it is one that can be achieved in production. The basis for this fuel cycle is an advanced actinide burner reactor with an assumed fuel burn-up of $100 \mathrm{GWD} / \mathrm{t}$.

The target burn-up for the reactor core is $100 \mathrm{GWd} / \mathrm{t}$. Due to the design of the core for a reactor with a $\mathrm{CR}<1$ using target blankets the maximum burn-up achieved during the first pass in AREVA's experience will be in the range of $68 \mathrm{GWd} / \mathrm{t}$ average across the core.

The Pu discharged from the fast reactor can be sent to a repository (One-Pass cycle) or recycled and additional energy extracted. For the multi-cycle option, a feed of recycled MOX fuel produced from LWR UOx spent fuel is still required to replenish the Pu consumed in order to sustain a constant annual energy production. Both of these options are presented in Figure 1.

Subsequent cycles of this design of burner reactor eventually reach fuel burn-ups of $76 \mathrm{GWd} / \mathrm{t}$., (Cycle 9). This higher burn-up is a result of the slightly higher Pu loading in each subsequent fuel cycle compared to the previous. It should be noted that the purpose of this reactor is to destroy Pu. This takes place by either fissioning it or by transmuting it to another isotope. Efficient use of the fissile material was not an objective of the design.

\subsubsection{CR $\approx 1$ :-BREAK EVEN}

This fuel produces as much Pu as it consumes and can therefore sustain itself with no additional Pu from recycle of UNF from LWR's. A fast reactor with this conversion ratio requires a feed of fast reactor MOX fuel with approximately $16 \% \mathrm{Pu}$ in the heavy metal [2] for the One-Pass cycle. To achieve multiple 
recycle of the SFR used MOX the Pu content will have to be increased with each subsequent cycle to compensate for the reduction in fissile Pu. For optimum performance an assumed fuel burn-up of $100 \mathrm{GWD} / \mathrm{t}$ has been assumed. The mass balance for this cycle is presented in Figure 2.

\subsubsection{CR > 1:-BREEDER REACTORS}

This fuel cycle represents using a fast reactor core design that produces significantly more Pu than it consumes. It is similar to the cycle for a fast reactor with $\mathrm{CR} \approx 1$ except that it produces sufficient surplus $\mathrm{Pu}$ that it can also sustain LWR MOX cycles or be used to provide fuel for additional SFR's. for the purpose of this study it is assumed that only one pass through an LWR will be conducted. A CR of 1.2 was selected to represent this class of fuel cycle. While this is not the largest possible CR, it is one that is realistic from an engineering perspective. This fuel cycle will require a small feed of tails uranium as feedstock for the additional targets which produce additional $\mathrm{Pu}$. A fast reactor with this conversion ratio requires a feed of fast reactor MOX fuel with $16 \%$ Pu in the heavy metal [2] for the One-Pass cycle. A multi-cycle fuel cycle is estimated. It should be noted that by cycle 9 the feed Pu loading will need to e increased to approximately $22.7 \% \mathrm{Pu}$ to compensate for the reduction in fissile Pu loaded into the fuel. For optimum performance of this fuel cycle a fuel burn-up of $100 \mathrm{GWD} / \mathrm{t}$ has been assumed for the driver fuel and a burnup of $12.7 \mathrm{GWD} / \mathrm{t}$ for the blankets.

One of the characteristics of this fuel cycle is that it produces a stream of MOX fuel for use in an LWR. The energy extracted from the LWR fuel is considered as an option. The mass balance for a once through and multiple recycle are presented in Figure's 3 and 4.

\subsection{ENERGY CONSUMPTION DATA}

As per previous calculations in the main body of the report the energy consumption data for the SFR fuel cycle facilities are based on the ratio of the size of the batch of material divided by the design basis throughput of the facility. The basis for energy consumption is summarized in Table 1.

Table 1. Fuel Processing Energy Consumption Bases

\begin{tabular}{|l|c|c|c|}
\hline & $\begin{array}{c}\text { Facility Throughput, } \\
\text { t/y }\end{array}$ & $\begin{array}{c}\text { Energy Consumption, } \\
\text { GWhe/y }\end{array}$ & $\begin{array}{c}\text { Unit Energy } \\
\text { Consumption, } \\
\text { GWhe/t }\end{array}$ \\
\hline Used UOx Recycling & 800 & 416 & 0.52 \\
\hline MOX Fuel Fabrication & 100 & 43 & 0.43 \\
\hline $\begin{array}{l}\text { Fast Reactor UOX Blankets } \\
\text { Fabrication (Based on RepU } \\
\text { Fabrication Facility) }\end{array}$ & 59 & 3 & 0.051 \\
\hline
\end{tabular}

For the SFR with a CR > 1 axial and radial blankets of UOx will be required. This blanket material contains no Pu and is therefore not MOX fuel. The energy consumed to produce the MOX and UOx fuel is based on the following assumptions.

1. The recycle of the used UOx and used MOX will require the same energy per tHM of feed material as the $800 \mathrm{tHM} / \mathrm{y}$ recycling facility, $416 \mathrm{GWh} / \mathrm{y}$ for $800 \mathrm{t} / \mathrm{y}$.

2. The MOX fuel fabrication will require $43 \mathrm{GWh} / \mathrm{y}$ for $100 \mathrm{t} / \mathrm{y}$ of MOX fuel fabricated. This energy consumption is applied to both fast reactor MOX fuel and LWR MOX fuel since they both require the special manufacturing considerations pertinent to Pu fuel. 
3. The UOx fuel for fast reactor radial and axial blankets does not contain Pu and therefore the fabrication and fabrication energy consumption of this fuel will be similar to that of RepU fuel. This fuel is not enriched and therefore will not require conversion and enrichment. The fabrication is therefore requires $3 \mathrm{GWh} / \mathrm{y}$ for each $59 \mathrm{t} / \mathrm{y}$ produced.

4. The thermal efficiency of the LWR is assumed to be 33\%. The thermal efficiency of the SFR is assumed to be $40 \%$. This is due to the higher operating temperature of the fast reactor compared to the LWR.

5. The axial blanket fuel fabrication energy consumption will be included with the MOX fuel fabrication energy consumption. This is because the material will be located in the same MOX fuel assembly rods with the Pu bearing material in the center of each rod and the UOx material placed above and below.

6. $\quad$ For the multiple recycle options there are numerous scenarios that can be considered particularly in the case where the CR $>1$. The scenario considered in this report is LWR MOX to SFR MOX for first cycle. Fuel is then recycled with excess Pu manufactured into one pass LWR MOX that is not recycled.

7. The energy consumed for multiple recycle is an approximation based upon the assumptions that have been carried through-out this calculation in this report.

\subsection{ENERGY PRODUCTION}

The Recycle Center will recover 7.9t of Pu in the 100 t/y of used MOX fuel and the $59 \mathrm{t} / \mathrm{y}$ of used RepU fuel. The thermal energy produced by the recycled fuel is the amount of each type of fuel multiplied by the discharge burnup. The energy is provided as electrical energy provided to the electric grid. The overall plant efficiency is assumed to be $40 \%$ for the fast reactor and 33\% for the LWR. The net electrical energy produced per year is provided in Tables 2, 3, and 4.

Table 2. Summary of Annual Energy Produced and Consumed in Fast Reactor Fuel Cycles for Burner SFR with CR<1

\begin{tabular}{|c|c|c|c|c|c|c|}
\hline Fuel Cycle & $\begin{array}{c}\text { \% Pu } \\
\text { In SFR } \\
\text { MOX }\end{array}$ & $\begin{array}{c}\text { Fuel } \\
\text { Throughput, } \\
\text { t/y }\end{array}$ & $\begin{array}{c}\text { Discharge } \\
\text { Burnup, } \\
\text { GWD/t }\end{array}$ & $\begin{array}{c}\text { Energy } \\
\text { Produced, } \\
\text { GWhely }\end{array}$ & $\begin{array}{c}\text { Energy } \\
\text { Consumed, } \\
\text { GWhely }\end{array}$ & EROI* $^{*}$ \\
\hline One-Pass & 30.8 & 25.6 & 68 & 16,700 & 94 & $177^{\star}$ \\
\hline
\end{tabular}

*The EROI calculation in this table does not include the energy consumed or produced by earlier recycle of the original 800 tHM of UOx Fuel used to produce the original feed material for this fuel cycle.

Energy Produced 25.6 x 68 x 24 x 0.4 = 16,700 GWhe/y

\section{Energy Consumed One Pass}

Energy Consumed Recycle Used MOX and RepU

Energy Consumed to manufacture SFR MOX $(100+59) \times 416 / 800=83$ GWhe/y

Total Energy Consumed 83+ 11= 94 GWhe/y 25.6 x 43/100 = 11 GWhe/y 
Table 3. Summary of Annual Energy Produced and Consumed in Fast Reactor Fuel Cycles for Break Even SFR CR $\approx 1$

\begin{tabular}{|l|c|c|c|c|c|c|}
\hline \multicolumn{1}{|c|}{ Fuel Cycle } & $\begin{array}{c}\text { \% Pu } \\
\text { In SFR } \\
\text { MOX }\end{array}$ & $\begin{array}{c}\text { Fuel } \\
\text { Throughput, } \\
\text { t/y }\end{array}$ & $\begin{array}{c}\text { Discharge } \\
\text { Burnup, } \\
\text { GWD/t }\end{array}$ & $\begin{array}{c}\text { Energy } \\
\text { Produced, } \\
\text { GWhely }\end{array}$ & $\begin{array}{c}\text { Energy } \\
\text { Consumed, } \\
\text { GWhely }\end{array}$ & EROI* $^{*}$ \\
\hline One-Pass & 16.35 & 48.4 & 100 & 46,400 & 104 & $446^{*}$ \\
\hline Multi-Cycle & 22.7 & 48.4 & 100 & 46,400 & 46.0 & $1000^{*}$ \\
\hline
\end{tabular}

*The EROI calculation in this table does not include the energy sonsumed or produced by earlier recycle of the original $800 \mathrm{tHM}$ of UOx Fuel used to produce the original feed material for this fuel cycle.

Energy Produced per cycle 48.4. x 100 x 24 x $0.4=46,400$ GWhe/y

\section{Energy Consumed One Pass}

Energy Consumed Recycle Used MOX and RepU $\quad(100+59)$ x 416/800 = 83 GWhe/y

Energy Consumed to manufacture SFR MOX $48.4 \times 43 / 100=21$ GWhe/y

Total Energy Consumed for one pass $83+21=104$ GWhe/y

Approximate Energy Consumed for each subsequent Recycle

Energy Consumed for each subsequent recycle

48.4 x 416/800 = 25 GWhe/y

Energy Consumed to manufacture SFR MOX

$48.4 \times 43 / 100=21$ GWhe/y

Total Energy Consumed for subsequent recycle $25+21=46$ GWhe/y

Table 4. Summary of Annual Energy Produced and Consumed in Fast Reactor Fuel Cycle for Breeder SFR CR>1

\begin{tabular}{|c|c|c|c|c|c|c|}
\hline Fuel Cycle & $\begin{array}{l}\% \text { Pu In } \\
\text { SFR MOX }\end{array}$ & $\begin{array}{c}\text { Fuel } \\
\text { Throughput, } \\
\text { t/y }\end{array}$ & $\begin{array}{c}\text { Discharge } \\
\text { Burnup, } \\
\text { GWD/t }\end{array}$ & $\begin{array}{l}\text { Energy } \\
\text { Produced, } \\
\text { GWhely }\end{array}$ & $\begin{array}{l}\text { Energy } \\
\text { Consumed, } \\
\text { GWhely }\end{array}$ & EROI* \\
\hline \multicolumn{7}{|c|}{ ONE-PASS RECYCLE ENERGY } \\
\hline SFR MOX & 16.35 & 48.4 & 100 & 46,500 & 104 & \\
\hline SFR UOx & 0.0 & 29.5 & 12.7 & 3,600 & 1.5 & \\
\hline Total & & & & 50,100 & 105.5 & $474^{*}$ \\
\hline \multicolumn{7}{|c|}{ MULTI-CYCLE RECYCLE ENERGY } \\
\hline SFR MOX & 22.7 & 48.4 & 100 & 46,500 & 46 & \\
\hline SFR UOx & 0.0 & 29.5 & 12.7 & 3,600 & 16.5 & \\
\hline LWR MOX & 9.6 & 13.7 & 50 & 5,400 & 6 & \\
\hline Total & & & & 55,500 & 68.5 & $791^{*}$ \\
\hline
\end{tabular}

*The EROI calculation in this table does not include the energy consumed or produced by earlier recycle of the original 800 tHM of UOx Fuel used to produce the original feed material for this fuel cycle.

One Pass Energy Produced

48.4 × $100 \times 24 \times 0.4=46,500$ GWhe/y (SFR)

$29.5 \times 12.7 \times 24 \times 0.4=3,600$ GWhe/y (SFR)

Total 46,500 +3,600 = 50,100 GWhe/y

One Pass Energy Consumed

Energy Consumed Recycle Used MOX and RepU

Energy Consumed to manufacture SFR MOX

$(100+59) \times 416 / 800=83$ GWhe/y

Energy Consumed to manufacture SFR UOx (RepU)

48.4 x 43/100 = 21 GWhe/y

Total $83+21+1.5=105.5$ GWhe/y

$29.5 \times 3 / 59=1.5$ GWhe/y 


\title{
Multiple Recycle
}

\author{
Approximate Energy Produced for each subsequent Recycle \\ 48.4 × $100 \times 24$ × $0.4=46,500$ GWhe/y (SFR MOX) \\ $29.5 \times 12.7 \times 24 \times 0.4=3,600$ GWhe/y (SFR UOx) \\ 13.7 x 13.7 x 50 x $0.33=5,400$ GWhe/y (LWR MOX) \\ Total 46,500 +3,600+5,400 = 55,500 GWhe/y
}

\begin{abstract}
Approximate Energy Consumed for each subsequent Recycle Energy Consumed for each subsequent recycle SFR MOX $\quad 48.4$ x 416/800 = 25 GWhe/y Energy Consumed to manufacture SFR MOX Energy Consumed for UOx Recycle Energy Consumed for SFR UOx (Based on RepU) Energy Consumed for LWR MOX Manufacture Energy consumed for LWR MOX Recycl

$$
\begin{aligned}
& 48.4 \times 43 / 100=21 \mathrm{GWhe} / \mathrm{y} \\
& 29.5 \times 416 / 800=15 \mathrm{GWhe} / \mathrm{y} \\
& 29.5 \times 3 / 59=1.5 \mathrm{GWhe} / \mathrm{y} \\
& 13.7 \times 43 / 100=6 \mathrm{GWhe} / \mathrm{y} \\
& \text { Assumed once through only }
\end{aligned}
$$
\end{abstract}

Total Energy Consumed for subsequent recycle $25+21+15+1.5+6=68.5$ GWhe/y

\subsection{SUMMARY}

Table 3 presents the data which is the basis for calculation of the Energy Return on Investment for the Two-Pass use of used MOX and RepU fuel and also the EROI for each fuel cycle. It should be noted that these numbers are on the same basis as those presented in the main report in that they are based on energy consumed in operations and do not include the energy required to construct and decommission the facilities.

Figures 1 through 4 depict the heavy metal mass flow and energy consumption and production. Figure 1 show the one-pass and multi-pass cycles for fast reactors with a CR $<1$. Figure 2 shows the one-pass and multi-pass cycles for fast reactors with a CR $\sim 1$. Figure 3 shows the one-pass cycle for fast reactors with a CR $>1$. Figure 4 shows the multi-pass cycle for fast reactors with a CR $>1$.

In general, higher EROI values are obtained for fuel cycles that recycle only spent fuel that contains higher concentrations of Pu. Fuels such as spent UOx contain much lower concentrations of $\mathrm{Pu}$ and therefore, require more recycling, and more feed material in order to obtain a given amount of $\mathrm{Pu}$. This increases the energy consumed and reduces the EROI.

\subsection{REFERENCES}

1. AREVA. Technical Report, RPT-3001161-000 April 30, 2009.

2. D. Verrier. RE: Question to Support Study in US for DOE. AREVA SAS, March 31, 2011. Email. 


\section{Figure 1. One-Pass and Multi-Pass Cycles for Fast Reactors with a $C R<1$}

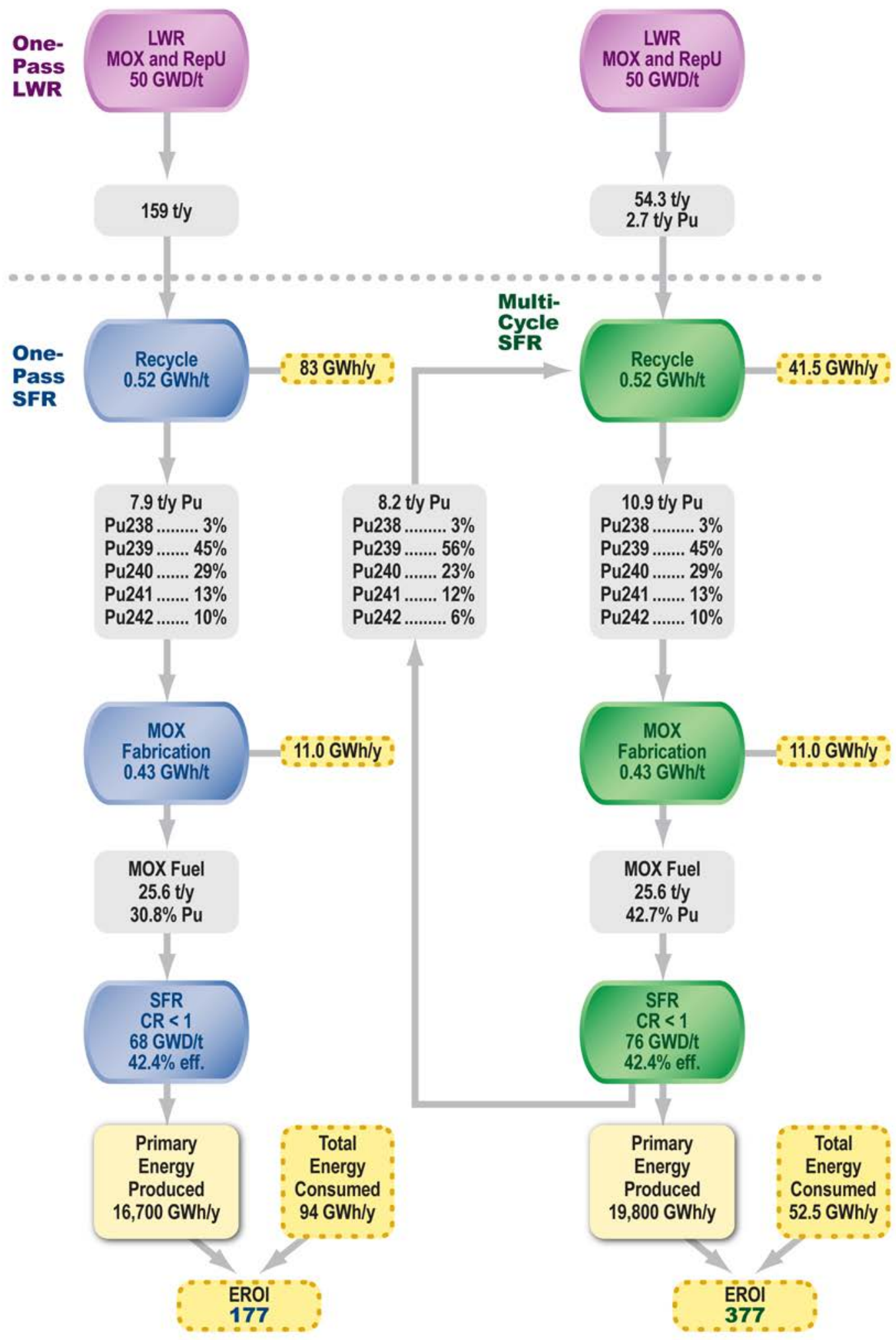


Figure 2. One-Pass and Multi-Pass Cycles for Fast Reactors with a $C R \approx 1$

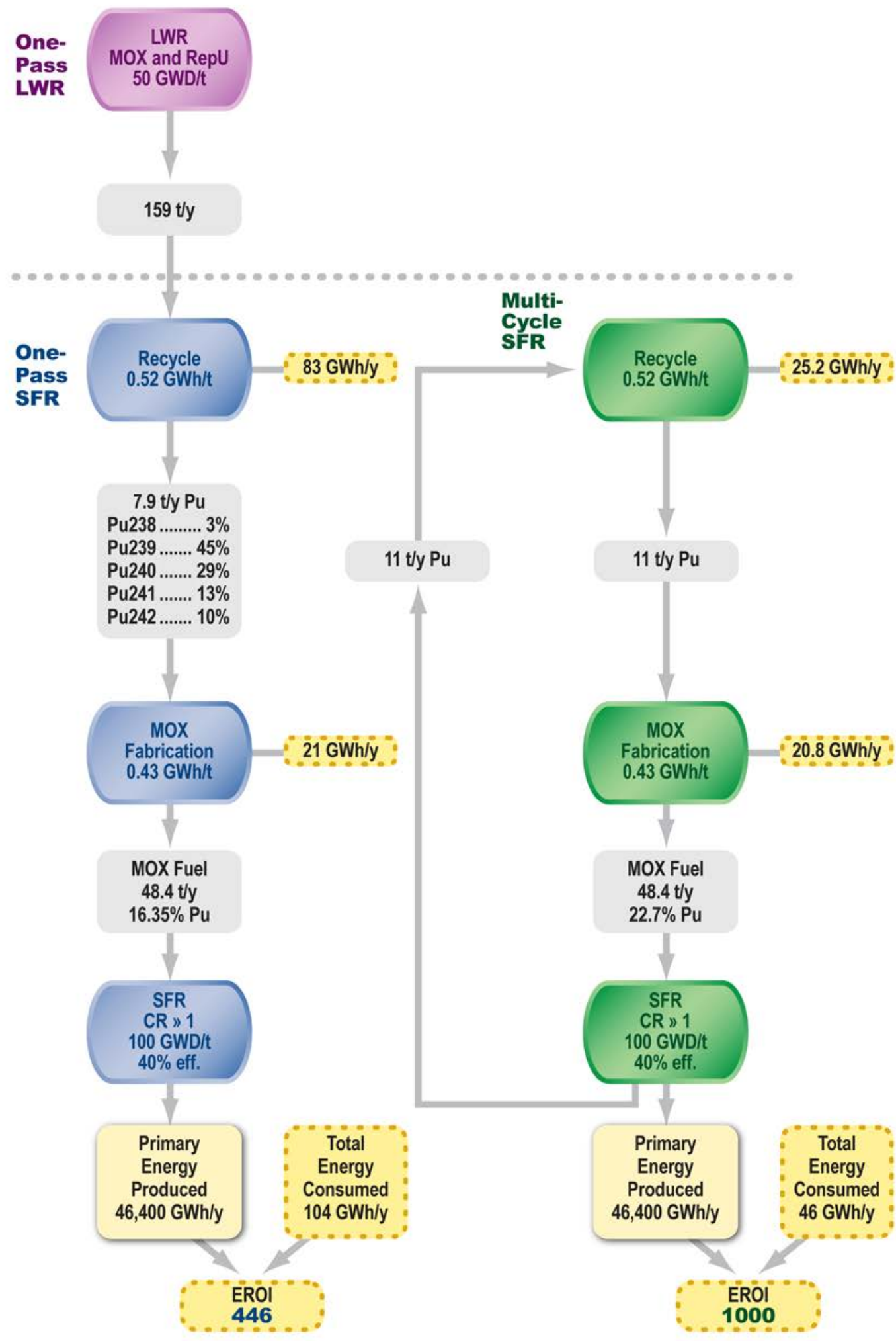


Figure 3. One-Pass Cycle for Fast Reactors with a CR $>1$

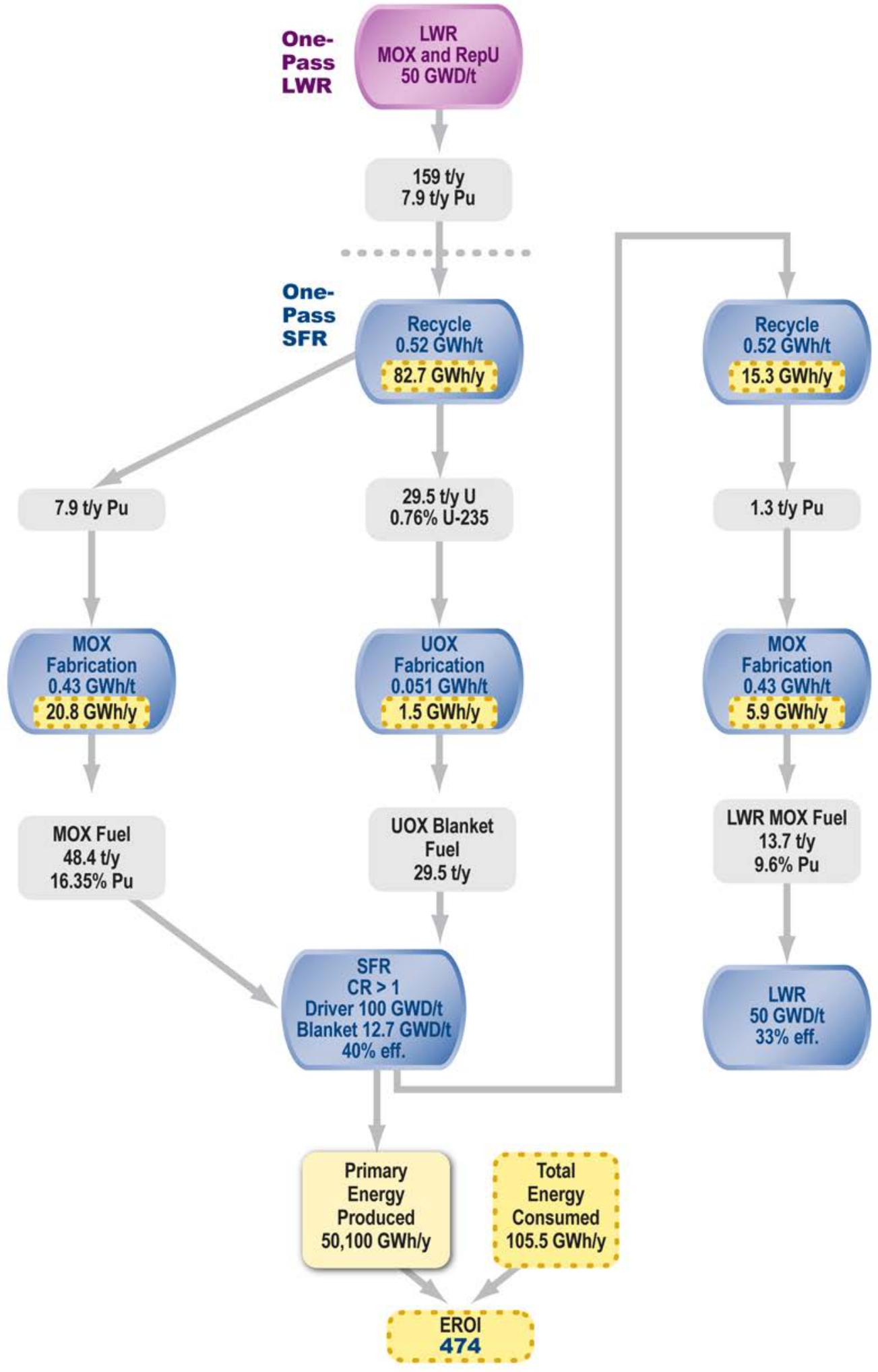


Figure 4. Multi-Pass Cycle for Fast Reactors with a CR $>1$

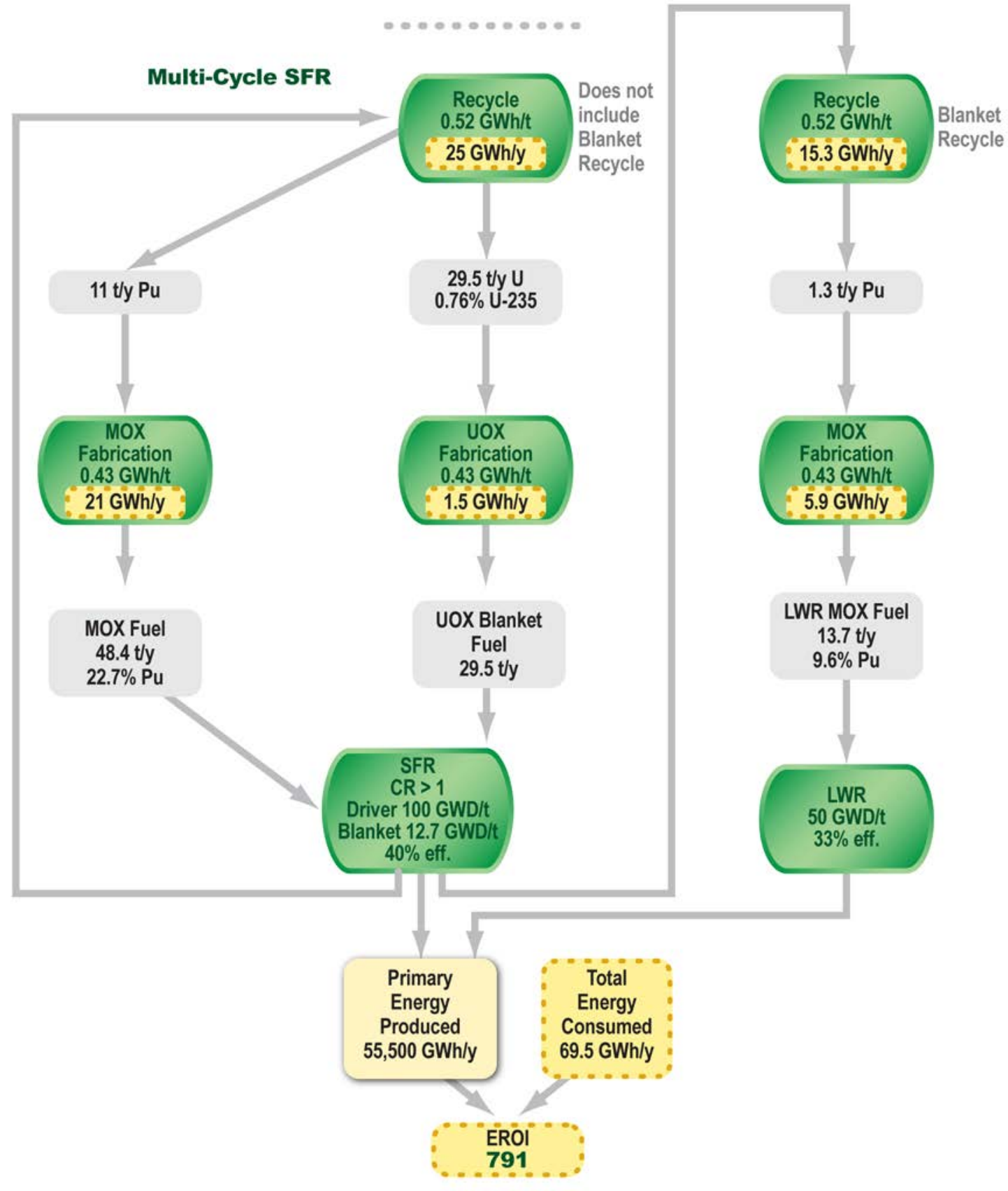




\section{Appendix D}

\section{Energy Required to Construct and Decommission a Sodium Fast Reactor}




\subsection{INTRODUCTION}

This appendix provides an estimate of the final energy consumed during the construction and decommissioning of a Generation IV Sodium Fast Reactor (SFR).

$>$ The energy consumed during the construction phase includes the production of the principle raw construction materials, refinement of those materials into useful forms and installation of the materials as part of the construction of the SFR.

$>$ The energy consumed during the dismantling phase includes, decommissioning a SFR including dismantling and disposal of the contaminated materials.

Energy consumption analysis will only consider primary processes that are expected to be significant contributors to the total energy consumed during the construction and decommissioning phase of the SFR.

Energy consumption for the extraction, transportation and manufacture of the building materials concrete and reinforcing bars and subsequent decommissioning is based on industry publications and in house experience, and provides a reasonable approximation for use in determining the energy required to construct and dismantle a SFR.

\subsection{SUMMARY OF ENERGY CONSUMED}

Table 1. Summary of Energy Consumed, by Phase and Type

\begin{tabular}{|l|c|c|c|c|c|}
\hline \multirow{2}{*}{} & \multicolumn{2}{|c|}{ Construction } & \multicolumn{3}{c|}{ Decommissioning } \\
\cline { 2 - 6 } & $\begin{array}{c}\text { Concrete } \\
\text { GWh/Mwe }\end{array}$ & $\begin{array}{c}\text { Reinforcing } \\
\text { Steel } \\
\text { GWh/Mwe }\end{array}$ & $\begin{array}{c}\text { Electricity } \\
\text { GWh/Mwe }\end{array}$ & $\begin{array}{c}\text { Natural Gas } \\
\text { GWh/Mwe }\end{array}$ & $\begin{array}{c}\text { Diesel } \\
\text { GWh/Mwe }\end{array}$ \\
\hline $\begin{array}{l}\text { Nominal } \\
\text { Values }\end{array}$ & 0.0364 & 0.1797 & 0.1251 & 0.2195 & 0.0596 \\
\hline $1100 \mathrm{MWe}$ & 40 & 198 & 138 & 241 & 66 \\
\hline
\end{tabular}

\section{Total Energy for construction and Decommissioning for each 1100 SFR}

$$
40+198+138+241+66=682 \text { GWh per reactor }
$$

\section{Construction Materials Considered}

For the purposes of this study the Sodium Fast Reactor (SFR) considered in the scenarios was sized at approximately 1100 GWe. Table 2 contains published ${ }^{1}$ information on the relative concrete volume and steel weight for seven types of reactors. It also contains the following information from the World Nuclear Organization ${ }^{2}$.

$>$ Sizewell B: $1188 \mathrm{MWe}, 520,000 \mathrm{~m}^{3}$ concrete ( $\left.438 \mathrm{~m}^{3} / \mathrm{MWe}\right), 65,000 \mathrm{t}$ rebar ( $55 \mathrm{t} / \mathrm{MWe}$ );

$>$ AP1000: $1100 \mathrm{MWe},<100,000 \mathrm{~m}^{3}$ concrete $\left(90 \mathrm{~m}^{3} / \mathrm{MWe}\right),<12,000 \mathrm{t}$ rebar $(11 \mathrm{t} / \mathrm{MWe})$. 
Table 2. Material Quantities vs Reactor Type

\begin{tabular}{|l|c|c|c|c|}
\hline Reactor Type & Power Level & $\begin{array}{c}\text { Building Volume, } \\
\text { cu-m/MWe }\end{array}$ & $\begin{array}{c}\text { Concrete Volume, } \\
\text { cu-m/MWe }\end{array}$ & $\begin{array}{c}\text { Steel Weight, } \\
\text { Tonnes/MWe }\end{array}$ \\
\hline 1970s PWR & 1000 & 340 & 75 & 37 \\
\hline 1970s BWR & 1000 & 390 & 88 & 41 \\
\hline EPR & 1600 & 400 & 130 & 44 \\
\hline ABWR & 1380 & 450 & 140 & 46 \\
\hline ESBWR & 1500 & 320 & 69 & 33 \\
\hline GT-MHR & 286 & 410 & 76 & 16 \\
\hline AHTR-IT & 1235 & 150 & 42 & 55 \\
\hline Sizewell & 1188 & & 440 & 11 \\
\hline P1000 & 1117 & & 90 & \\
\hline
\end{tabular}

This data is expressed in terms of units per MWe. It should also be noted that there is a large amount of uncertainty in some of the estimates and therefore the data is only good to one or two significant digits.

Plotting the data reveals no real trend with reactor size for either concrete volume or steel weight. However it can be expected that the non-pressurized, SFR's, would have a lower concrete volumes and steel weights than other reactor designs. This is due to their low operating pressure, which avoids the use of thick pressure vessels and piping, and also avoids the necessity of large makeup tanks and vapor suppression for accident mitigation.

\section{Construction Material Takeoffs}

The quantities of concrete, excavation and weight of steel for a nominal 1100 MWe SFR were estimated after considering the information for several reactor types ${ }^{1}$, including Light water reactors (LWRs) and gas-cooled reactors. The following quantities were selected so that the energy costs for construction and decommissioning can be provided per MWe.

$\begin{array}{ll}>\text { Concrete } & 76 \mathrm{~m}^{3} \text { per MWe } \\ \text { Steel } & 27 \text { Tons per MWe }\end{array}$

\section{Construction Energy Consumed-Metrics}

The following materials/work processes are included in the analysis:

$>4000$ psi concrete (typical): Foundations, buildings

- Raw material production and transportation

- Batch-plant operations

- Transportation and installation

Metallic Components: Rebar

- Raw material production and transportation

- Mill operations and transportation

- Fabrication

- Transportation and installation

\subsubsection{CONCRETE PRODUCTION AND INSTALLATION}

Several research reports produced by the Athena Institute were utilized to provide an estimate of the energy required to produce, transport and place concrete ${ }^{3,4 \text {, and } 5}$. The research was conducted for 
Canadian producers and users, but was broken into regions. Only the more densely populated regions (West and East Coast) were used to determine an aggregate metric. The Central and Prairie regions were not included due to exceedingly high transportation costs, and were considered inconsistent with the average U.S. population density. The breakdown of the energy consumed is identified in Table 3.

Table 3. Production and Transportation Energy Requirements of Concrete GJ per Cubic Meter

\begin{tabular}{|c|c|c|c|c|}
\hline Extraction & Transportation & Processing & $\begin{array}{c}\text { Transportation between batch } \\
\text { plant and site and placement }\end{array}$ & Total Placed \\
\hline 0.089 & 0.074 & 1.549 & 0.012 & 1.724 \\
\hline
\end{tabular}

Table 3 makes it fairly clear that the bulk of the energy (89\% in this analysis) required to produce and place concrete lies in the processing. However, once the location of the site is determined, it may be necessary to re-calculate the transportation energy. Note the batch plant distance in this case is set at $10 \mathrm{~km}$ from the site.

\section{Metallic Production and Installation}

Due to the energy intense nature of the production of metal, there are a number of studies on which to draw metrics ${ }^{6}$, shown in Table 4.

Table 4. Energy per Step in Metallic Production by end Conformation, GJ per Tonne

\begin{tabular}{|l|c|c|c|c|c|c|c|}
\hline $\begin{array}{c}\text { Metallic } \\
\text { Elements }\end{array}$ & Extraction & $\begin{array}{c}\text { Extraction } \\
\text { Transportation }\end{array}$ & Processing & $\begin{array}{c}\text { Primary } \\
\text { Mill }\end{array}$ & $\begin{array}{c}\text { Finishing } \\
\text { Mill }\end{array}$ & $\begin{array}{c}\text { Transportation } \\
\text { to Site and } \\
\text { Installation }\end{array}$ & $\begin{array}{c}\text { Total } \\
\text { Installed }\end{array}$ \\
\hline $\begin{array}{l}\text { Steel } \\
\text { (rod) }- \\
\text { rebar }\end{array}$ & 2.59 & 0.63 & 18.83 & 1.28 & 0.00 & 0.63 & 23.96 \\
\hline
\end{tabular}

Note that the processing energy is again the bulk of the energy. In this case, the average processing energy is a cross section of both BOF (Blast Oxygen Furnace) type plants and EAF (Electric Arc Furnace). The average for the studies identified for BOF plants was 19 GJ per tonne, and the energy for EAF plants is closer to $8 \mathrm{GJ}$ per tonne. The industry is moving to the more efficient EAF process, but is still dominated by BOF facilities. Note also that the transportation to site is the same as the extraction transportation. This is due to the assumption that the averages established for the transportation of the raw materials, will extend to the average distance required to transport the finished product to the site from the mill.

\section{Construction Energy Consumed - Results}

Table 5. Energy Requirements for Instalation of Concrete

\begin{tabular}{|c|c|}
\hline & Concrete GWh/Mwe \\
\hline SFR & 0.0364 \\
\hline
\end{tabular}

Table 6. Energy Requirements for Fabrication and Instalation of Rebar

\begin{tabular}{|c|c|}
\hline & Reinforcing Steel GWh/Mwe \\
\hline SFR & 0.1797 \\
\hline
\end{tabular}




\section{Decommissioning Materials Considered and Quantity Estimation}

In 1996, DOE submitted a preliminary Environmental Impact Statement (EIS) for the West Valley Demonstration Project8, a former fuel reprocessing and vitirification facility. This EIS was updated in 2007 and listed quantities of material to be decommissioned, and the energy requirements to complete the decommissioning, transportation and complete disposal. Key quantities identified in the EIS include

$>$ Cubic meters of concrete

$>$ Tonnes of steel

$>$ Cubic meters of soil

$>$ Other Non-Hazardous

These identified quantities where utilized to scale the estimated energy requirements for the SFR. The ratio of the total quantity of concrete between the WVDP and the three areas identified, were used to estimate the quantities of the soil and "Other non-hazardous" materials.

$>$ Ratio of WVDP Concrete Volumes to SFR Concrete Volumes on a per MWe basis - $76 / 61280=0.000173$

The key quantities identified (concrete and steel) and the estimated quantities (soil and other nonhazardous) are identified in Table 7.

Table 7. Key Quantities for Determining Decommissioning Energy Requirements.

\begin{tabular}{|c|c|c|c|c|}
\hline Facility & $\begin{array}{c}\text { Concrete Cubic } \\
\text { Meters/MWe }\end{array}$ & $\begin{array}{c}\text { Steel } \\
\text { Tonnes/MWe }\end{array}$ & $\begin{array}{c}\text { Soil Cubic } \\
\text { Meters/MWe }\end{array}$ & $\begin{array}{c}\text { Other Non-Hazardous } \\
\text { Cubic Meters/MWe }\end{array}$ \\
\hline SFR & 76 & 27 & 1373 & 24 \\
\hline
\end{tabular}

\section{Decommissioning Energy Consumed - Metrics}

The EIS includes the electricity, natural gas and diesel fuel expected to be used to decommission the WVDP. These quantities are factored by the key quantities ratio determined above to estimate the quantities required for the SFR.

Table 8. Utility Requirements for Decommissioning

\begin{tabular}{|c|c|c|c|}
\hline Facility & Electricity MW-Hrs/MWe & Natural Gas Cubic Meters/MWe & Diesel Liters/MWe \\
\hline SFR & 125 & 21,069 & 5,563 \\
\hline
\end{tabular}

Converting these quantities to energy, utilizing the following conversions:

$>3600 \mathrm{MJ}$ per MW-Hr

> $37.5 \mathrm{MJ}$ per Cubic Meter of Natural Gas

$>38.6 \mathrm{MJ}$ per Liter of Diesel 


\section{Decommissioning Energy Consumed - Results}

Table 9. Utility Requirements for Decommissioning

\begin{tabular}{|c|c|c|c|}
\hline Facility & $\begin{array}{c}\text { Electricity } \\
\text { GWh/MWe }\end{array}$ & $\begin{array}{c}\text { Natural Gas } \\
\text { GWh/MWe }\end{array}$ & $\begin{array}{c}\text { Diesel } \\
\text { GWh/MWe }\end{array}$ \\
\hline West Valley Demonstration Project & 0.1251 & 0.2195 & 0.0596 \\
\hline
\end{tabular}

Figure 1. Distribution of Estimated Energy Requirements of the SFR During Construction (GWh/MWe)

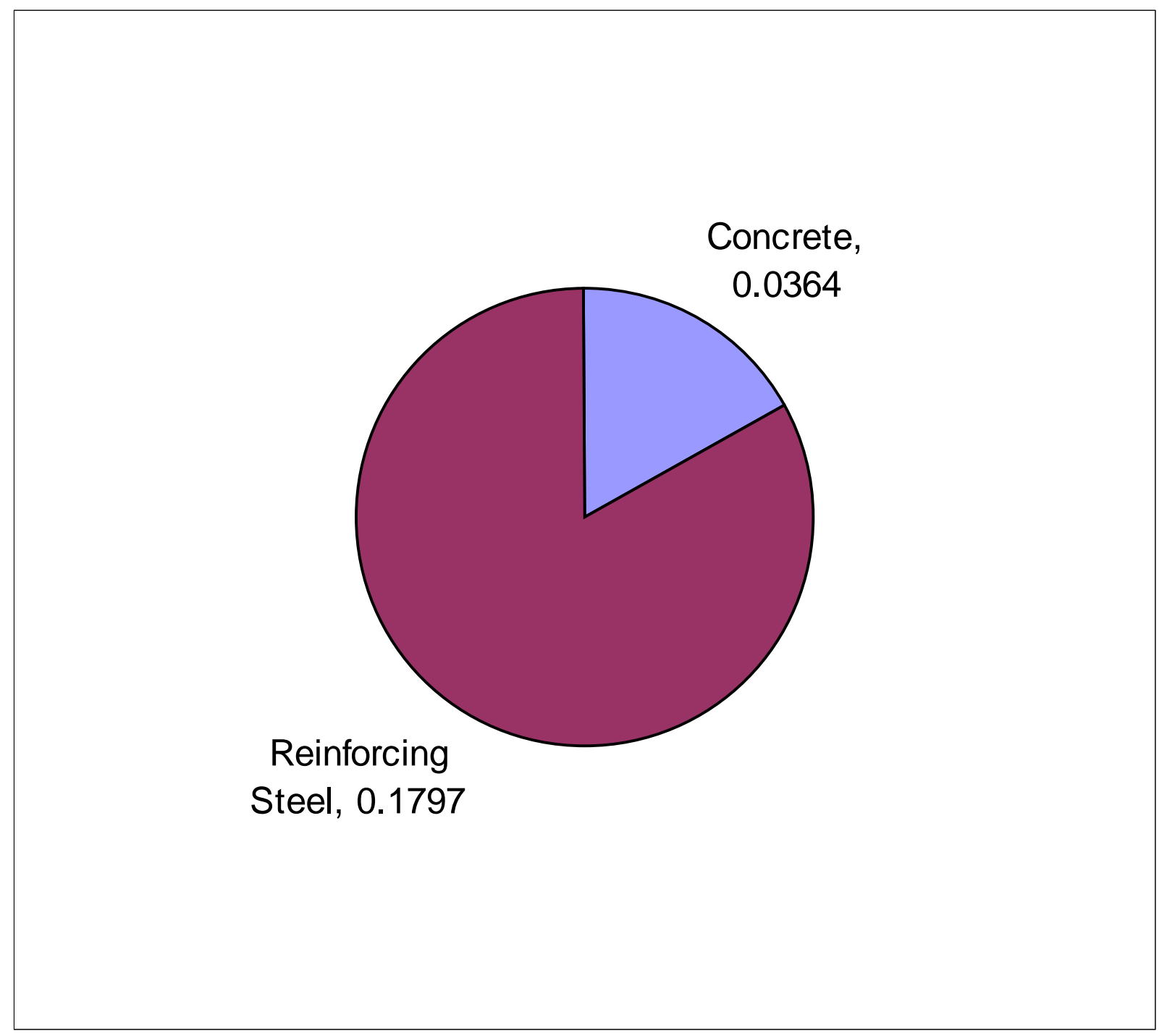


Figure 2. Distribution of Estimated Energy Requirements of the SFR During Decommissioning (GWh/MWe)

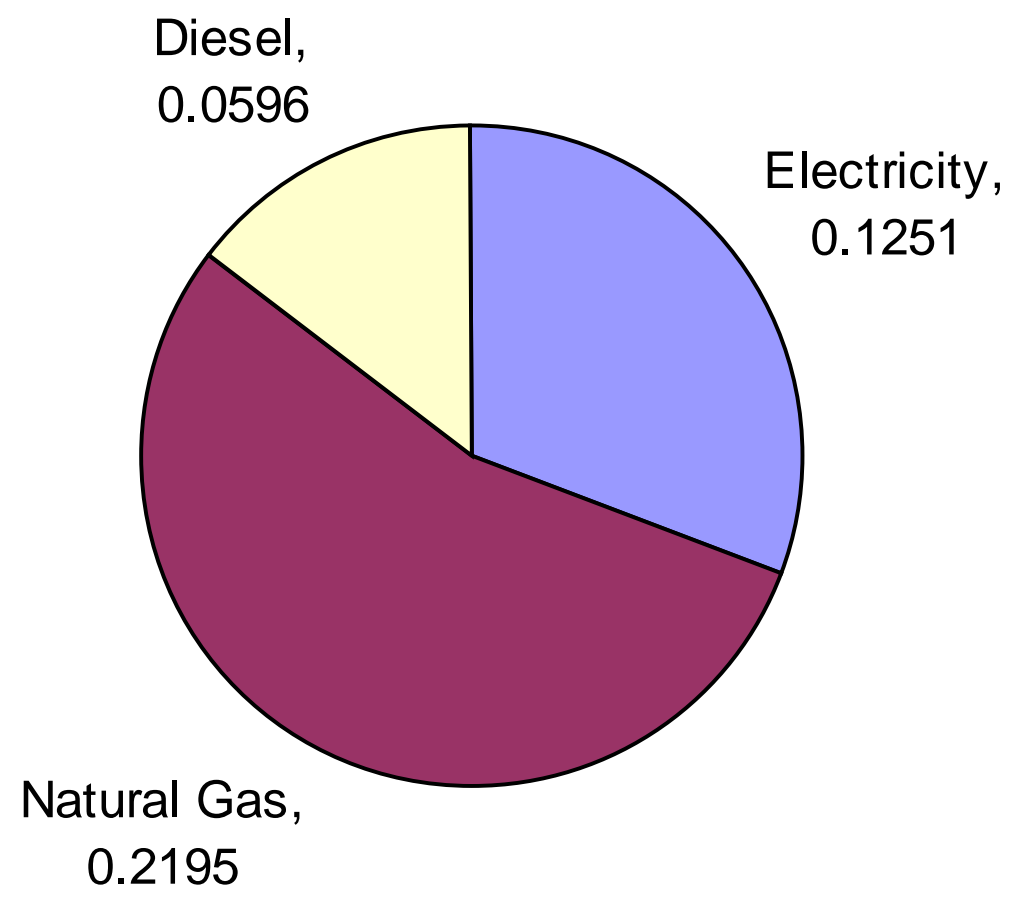




\section{References}

1. Per F. Peterson, Haihua Zhao, and Robert Petroski. Metal and Concrete Inputs for Several Nuclear Power Plants. UCBTH-05-001, Unviersity of California, Berkeley, February 4, 2003.

2. World Nuclear Association. Advanced Nuclear Power Reactors. http://www.worldnuclear. org/info/inf08.html, 25 March 2011.

3. Page Athena Institute CEMENT AND STRUCTURAL CONCRETE PRODUCTS: LIFE CYCLE INVENTORY UPDATE \#2 - 2005, Ottowa.

4. CEMENT AND STRUCTURAL CONCRETE PRODUCTS: LIFE CYCLE INVENTORY UPDATE, PREPARED BY VENTA, GLASER \& ASSOCIATES, OTTAWA, CANADA, OCTOBER 1999.

5. RAW MATERIAL BALANCES, ENERGY PROFILES AND ENVIRONMENTAL UNIT FACTOR ESTIMATES: CEMENT AND STRUCTURAL CONCRETE PRODUCTS, PREPARED BY CANADA CENTRE FOR MINERAL \& ENERGY TECHNOLOGY AND RADIAN CANADA INC., OTTAWA, CANADA, OCTOBER 1993.

6. ATHENA INSTITUTE, CRADLE TO GATE LIFE CYCLE ANALYSIS INVENTORY: CANADIAN AND US STEEL PRODUCTION BY TYPE, MARKUS ENGINEERING RESOURCES, MARCH 2002.

7. U.S. DEPARTMENT OF TRANSPORTATION, FEDERAL HIGHWAY ADMINISTRATION, DEVELOPMENT AND USE OF PRICE ADJUSTMENT CONTRACT PROVISIONS, DATE: DECEMBER 10, 980: HTTP://WWW.FHWA.DOT.GOV/PROGRAMADMIN/CONTRACTS/TA50803.CFM ACCESSED 5/1/11.

8. FINAL ENVIRONMENTAL IMPACT STATEMENT FOR DECOMMISSIONING AND/OR LONG-TERM STEWARDSHIP AT THE WEST VALLEY DEMONSTRATION PROJECT AND WESTERN NEW YORK NUCLEAR SERVICE CENTER - TABLES 4-3, 4-61. 